UNIVERSIDADE DE SÃO PAULO

FACULDADE DE FILOSOFIA, LETRAS E CIÊNCIAS HUMANAS DEPARTAMENTO DE LETRAS CLÁSSICAS E VERNÁCULAS PROGRAMA DE ESTUDOS COMPARADOS DE LITERATURAS DE LÍNGUA PORTUGUESA

\title{
LITERATURA E REPRESENTAÇÃO SOCIAL DAS MULHERES EM CABO VERDE: VENCENDO BARREIRAS
}

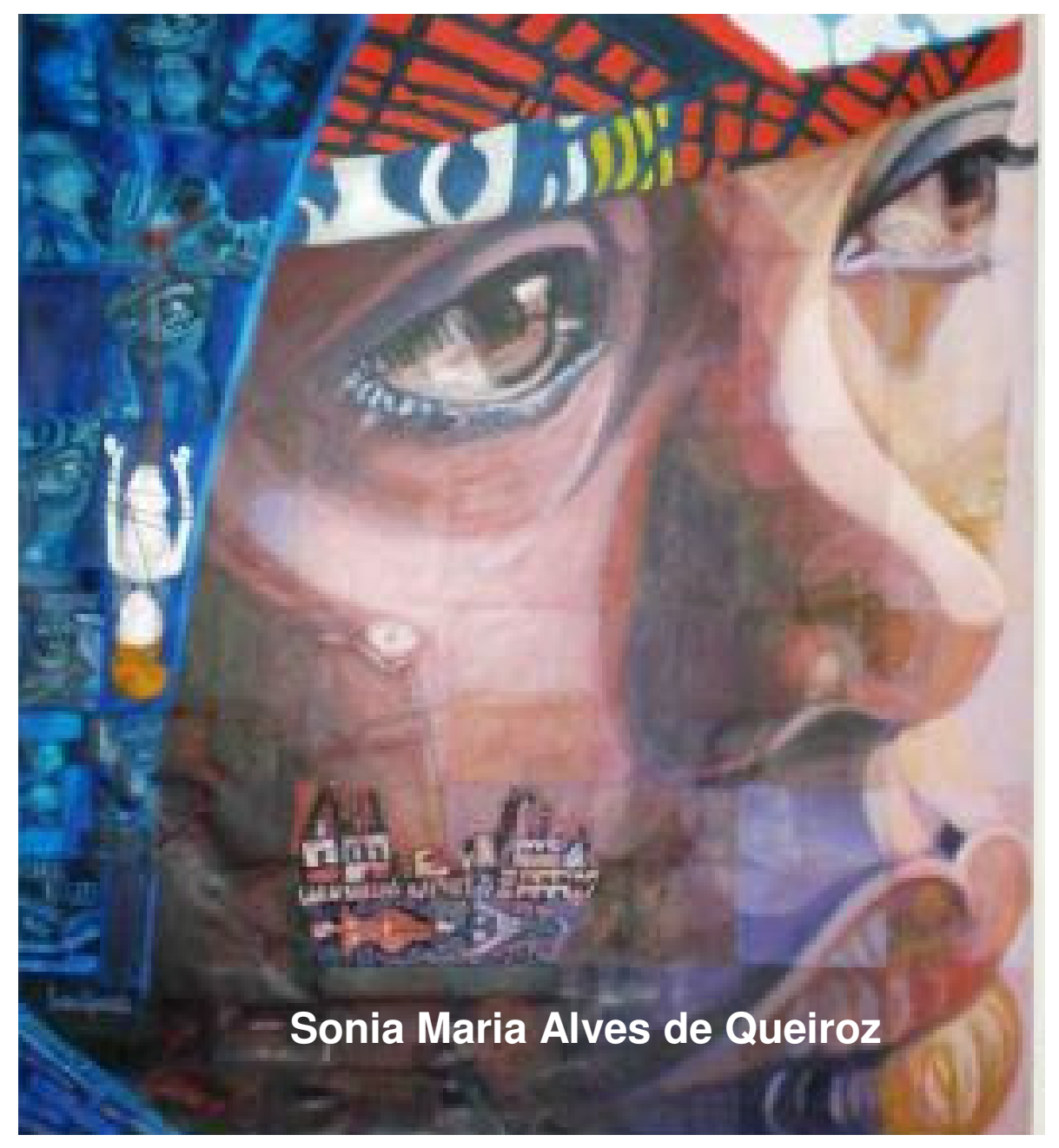

São Paulo 
UNIVERSIDADE DE SÃO PAULO

FACULDADE DE FILOSOFIA, LETRAS E CIÊNCIAS HUMANAS DEPARTAMENTO DE LETRAS CLÁSSICAS E VERNÁCULAS PROGRAMA DE ESTUDOS COMPARADOS DE LITERATURAS

DE LÍNGUA PORTUGUESA

\section{LITERATURA E REPRESENTAÇÃO SOCIAL DAS MULHERES EM CABO VERDE: VENCENDO BARREIRAS}

\section{Sonia Maria Alves de Queiroz}

Dissertação apresentada à Banca Examinadora do programa de Pós-Graduação em Estudos Comparados de Literaturas de Língua Portuguesa, do Departamento de Letras Clássicas e Vernáculas da Faculdade de Filosofia, Letras e Ciências Humanas da Universidade de São Paulo, como exigência parcial para obtenção do título de Mestre em Letras.

Orientadora: Profa. Doutora Simone Caputo Gomes 
Autorizo a reprodução e divulgação total ou parcial deste trabalho, por qualquer meio convencional ou eletrônico, para fins de estudo e pesquisa, desde que citada a fonte.

\author{
Catalogação da Publicação \\ Serviço de Documentação \\ Faculdade de Filosofia, Letras e Ciências Humanas
}

QUEIROZ, Sonia Maria Alves de.

Literatura e representação social das mulheres em Cabo Verde: vencendo barreiras / Sonia Maria Alves de Queiroz; Orientadora Simone Caputo Gomes. - São Paulo, 2010. 140 f.: il.

Dissertação (Mestrado)--Universidade de São Paulo, 2010.

1. Cabo Verde. 2. Mulheres. 3. Estudos Comparados de Literaturas de Língua Portuguesa. GOMES, Simone Caputo. II. Título: Literatura e representação social das mulheres em Cabo Verde: vencendo barreiras.

CDD 
UNIVERSIDADE DE SÃO PAULO

FACULDADE DE FILOSOFIA, LETRAS E CIÊNCIAS HUMANAS DEPARTAMENTO DE LETRAS CLÁSSICAS E VERNÁCULAS PROGRAMA DE ESTUDOS COMPARADOS DE LITERATURAS

DE LÍNGUA PORTUGUESA

LITERATURA E REPRESENTAÇÃO SOCIAL DAS MULHERES EM CABO VERDE : VENCENDO BARREIRAS

\section{Sonia Maria Alves de Queiroz}

Dissertação apresentada ao Programa de PósGraduação em Estudos Comparados de Literaturas de Língua Portuguesa, do Departamento de Letras Clássicas e Vernáculas da Faculdade de Filosofia, Letras e Ciências Humanas da Universidade de São Paulo, como exigência parcial para obtenção do título de Mestre em Letras, sob orientação da Profa. Doutora Simone Caputo Gomes.

Prof. Doutora. Simone Caputo Gomes

Orientadora/USP

São Paulo 


\section{DEDICATÓRIA}

IN MEMORIAM

Para minha mãe Creuza Rodrigues de Queiroz e minha irmã Selma Maria Alves de Queiroz, com Saudades. 


\section{AGRADECIMENTOS}

A minha orientadora e amiga, Professora Doutora Simone Caputo Gomes, pelo seu acolhimento, compromisso e dedicação, ao trilhar juntamente comigo este caminhar de amor e pedras. Sem sua mediação e perseverança não seria possível ter chegado até aqui.

Minha homenagem (in memoriam) à minha orientadora inicial, Professora Doutora Maria Aparecida Santilli.

Ao meu amigo e incentivador Professor Doutor Rubens Pereira Santos, pelo seu exemplo de humanismo e profissionalismo.

Ao meu companheiro de todas as horas, Antonio Carlos Ferreira Mathias, pelo apoio e compreensão dedicados a este trabalho.

Para meus queridos filhos Jonatan, Ligia e Louise, que durante esses anos souberam me apoiar e perdoar minha ausência, mesmo quando presente.

Aos meus amigos do Grupo de Estudos Cabo-verdianos CNPq/USP, pelos momentos amabilíssimos desfrutados nestes anos de convívio. 


\section{RESUMO}

QUEIROZ, Sonia Maria Alves de. Literatura e representação social das mulheres em Cabo Verde: vencendo barreiras. 2010. 140 f. Dissertação da área de Estudos Comparados de Literaturas de Língua Portuguesa. Universidade de São Paulo, São Paulo, 2010.

Esta dissertação analisa comparativamente textos cabo-verdianos de autoria masculina e feminina à luz do tema "Literatura e representação social das mulheres em Cabo Verde", com o objetivo de demonstrar como constroem a historicidade das mulheres naquele contexto, com base na abordagem de gênero e numa hermenêutica do cotidiano feminino. Diante do exposto, centramos as leituras nas personagens femininas das narrativas, especialmente as protagonistas, no intuito de acompanhar suas trajetórias de objetos a sujeitos históricos, tendo em conta a complexidade do fenômeno da emancipação feminina em Cabo Verde e a entrada um pouco tardia, todavia decisiva, de produções de mulheres no cânone literário. Buscamos demonstrar, em nossa pesquisa, como a escritura literária masculina de António Aurélio Gonçalves, Baltasar Lopes, Manuel Ferreira, Oswaldo Osório, Teobaldo Virgínio e Virgílio Pires apreende e apresenta realidades femininas, sobretudo por meio da exposição, ao passo que as escrituras literárias femininas de Camila Mont-Rond, Dina Salústio, Fátima Bettencourt, Ivone Aída e Maria Margarida Mascarenhas revelam subjetividades femininas que lançam novos olhares e novos recortes que dialogam o universo representado pela ótica masculina.

PALAVRAS-CHAVE: Cabo Verde - Literatura - Representação social das mulheres - Escritura literária de autoria masculina - Escritura literária de autoria feminina. 


\begin{abstract}
QUEIROZ, Sonia Maria Alves de. Literatura e representação social das mulheres em Cabo Verde: vencendo barreiras. 2010. 140 f. Dissertação da área de Estudos Comparados de Literaturas de Língua Portuguesa. Universidade de São Paulo, São Paulo, 2010.
\end{abstract}

This dissertation analyses comparatively Cape Verdean texts of masculine and feminine authorship by the light of the subject "Literature and social representation of the women in Cape Verde", with the objective to demonstrate how they build the historicity of women in that context, based on the approach gender and a hermeneutics of everyday women. Given the above, the readings have focused on female characters of the narratives, especially the protagonists in order to follow their paths of objects to historical subjects taking into account the complexity of the phenomenon of female emancipation in Cape Verde and coming a little late, but decisive, productions of women in the literary canon. We demonstrate in our research, such as male literary writings of António Aurélio Gonçalves, Baltasar Lopes, Manuel Ferreira, Oswaldo Osório Pires Teobaldo Virgínio and Virgílio Pires learns and presents women's realities, especially through the exhibition, while the female literary writings of Camila Mont-Rond, Dina Salústio, Fátima Bettencourt, Ivone Aída and Maria Margarida Mascarenhas and reveal female subjectivities that cast new visions and new cuts that dialogue the universe represented by the male perspective.

KEYWORDS: Cape Verde - Literature - Social representation of women - Texts of masculine authorship - Texts of feminine authorship. 


\section{SUMÁRIO}

Considerações introdutórias.

.11

Cap.1. Abordagem de gênero e hermenêutica do cotidiano: breves reflexões teóricas sobre a representação social das mulheres. 16

Cap. 2. A construção da história das mulheres cabo-verdianas: vencendo barreiras. .25

2.1. Mulheres cabo-verdianas, exclusão e discriminação social.............................25

2.2. Formas da discriminação. .33

Cap. 3. Literatura e representação social das mulheres em Cabo Verde. .46

3.1. A produção masculina apresenta as mulheres cabo-verdianas.....................51

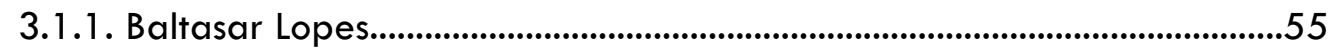

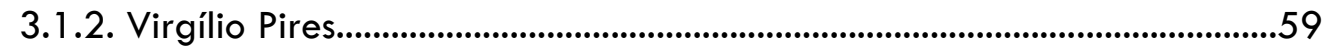

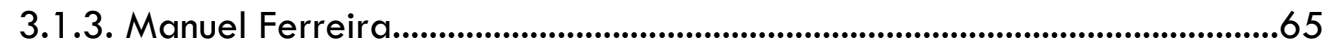

3.1.4. Teobaldo Virgínio................................................................................................73

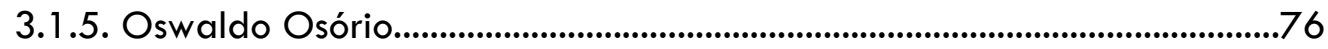

3.1.6. António Aurélio Gonçalves...........................................................................78

3.2. A produção feminina revela as mulheres cabo-verdianas ...............................85

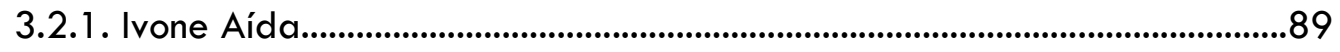

3.2.2. Dina Salústio.........................................................................................................99

3.2.3. Maria Margarida Mascarenhas (M.M.M.) ..................................................10 108

3.2.4. Camila Mont-Rond (Ondina Ferreira) .............................................................114

3.2.5. Fátima Bettencourt.................................................................................................. 118

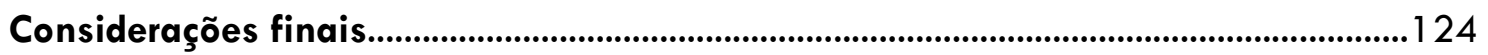

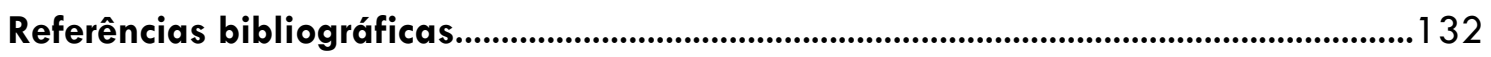

1. Obras literárias........................................................................................................132

2. Obras de abordagem teórica, crítica e contextual...........................................133

3. Webgrafia........................................................................................................................ 138 
"Este é um universo feminino [...].

Mas vendo bem, elas não são completamente estranhas. Já as vimos passeando pela novelística de Aurélio Gonçalves e pela poesia de Ovídio Martins, Onésimo Silveira, Gabriel Mariano e tantos outros.

Só que agora estão mais alegres, mais espontâneas, mais soltas e seguras."

Fátima Bettencourt 


\section{CONSIDERAÇÕES INTRODUTÓRIAS}

A literatura nos fornece sinais indiretos, muito mais que diretos, sobre a sociedade na qual circulou, ou circula. A literatura não nos diz como somos, mas, sim, como pensamos que somos, como desejamos ser , no limite, como não somos.

Cíntia Schwantes

O interesse em efetivar o estudo sobre a cultura cabo-verdiana e, em especial, sobrel a situação social da mulher naquele contexto, nasceu do nosso primeiro contato com o romance Chuva Braba, de Manuel Lopes, e com o conto "A Caderneta", de Baltasar Lopes. A temática da seca, da vida árdua dos cidadãos, a falta de recursos levando-os a emigrarem para terras desconhecidas, as injustiças sociais, a prostituição feminina e o descaso do Poder Público, à época das escrituras, foram questões que nos despertaram a atenção e, dentre eles, a problemática feminina e sua complexidade levou-nos a adentrar este universo a fim de compreender os motivos que levavam personagens a sofrer discriminação e até violência.

Em consonância com o que propõe Moisés (2002):

E se não houver denúncia? Faria alguma diferença? Denunciar é preciso. Ou seria navegar? Talvez, quem sabe, protestar. Mas que é preciso, é. Porque, se você percebe que o mundo está desordenado, ou você denuncia, ou a desordem continua.

Esta pesquisa pretende navegar, investigar como o discurso literário opera a representação social das mulheres em Cabo Verde, colocando lado a lado textos de autoria masculina e feminina, no sentido de observar como essas óticas de gênero poderão impactar os temas tratados.

Interessa-nos acompanhar a transfiguração do cotidiano das mulheres caboverdianas em arte sob um olhar feminino e sob um olhar masculino, no intuito de, pela comparação das perspectivas, observar como o discurso literário lê a relação entre os sexos, a partir de recortes culturais que diferenciam as práticas sociais de mulheres e homens, no arquipélago. 
Nossa primeira tarefa será buscar apoio para a elaboração de um arsenal teórico que possibilite o estudo desse objeto, o feminino, no âmbito da literatura, como propõe Schwantes (2003, p. 394). Sabe-se que, numa sociedade falogocêntrica, "a escrita feminina sempre negocia no estreito espaço entre o apagamento e a possibilidade de representação" (Ibidem, p. 397).

A pretensão deste trabalho é examinar como a representação literária trata questões relativas à exploração, à desigualdade entre os gêneros, à discriminação e violência a que são expostos seres humanos que, muitas vezes, estão em busca, tão somente, de meios de sobrevivência.

Justificamos o desenvolvimento deste projeto pelo interesse atual pelas causas das condições degradantes a que são submetidas muitas personagens mulheres nos textos selecionados. Verificamos que essas "mulheres de papel" nos remetem diretamente ao cotidiano cabo-verdiano, em que as mulheres desempenham papéis fundamentais (e não raro invisíveis) para a manutenção e sobrevivência familiar, chegando a usar o seu corpo como um meio para obter o mínimo para a cachupa (refeição) dos filhos.

Muitas personagens de ficção são representadas no anonimato para que possam melhor expressar, segundo a ótica da criação literária, a condição social de mulheres cabo-verdianas marginalizadas pela sociedade, sem valorização e historicização de suas lutas diárias frente a uma terra inóspita que quase nada tinha a lhes tem a oferecer do ponto de vista da qualidade de vida, segundo o contexto retratado por grande parte do corpus selecionado.

Destacaremos neste estudo, ainda, o tema da prostituição, recorrente na literatura desde o período nativista ou pré-claridoso, persistindo como referência em textos contemporâneos. As relações entre a vida cotidiana ao entorno dos portos e as migrações com a prostituição feminina serão também enfatizadas e contextualizadas.

O discurso literário será encarado, nos textos a examinar, como um veículo dos mais relevantes para mapear a história social das mulheres em Cabo Verde. $\mathrm{O}$ cotejo entre textos de autoria feminina e masculina auxiliará o acompanhamento da trajetória de conscientização e emancipação das mulheres naquele contexto, marcando outros olhares (e ações) alternativos à ótica masculino-paternalista que tem fundamentado a experiência vivida pelas mulheres cabo-verdianas, apontando para a ultrapassagem das formas de discriminação. 
Para depreender como a literatura cabo-verdiana representa a situação social das mulheres, partiremos de um corpus ficcional que se compõe de contos produzidos por escritores e escritoras do arquipélago: "A Caderneta”, de Baltasar Lopes; "Lulucha" e "Titina", de Virgílio Avelino Pires; "Bèlinha foi ao baile pela primeira vez" e "Uma flor entre os cardos", de Manuel Ferreira; "Beira de Cais", de Teobaldo Virgínio; "Rebindita" e "Borboleta evadida", de Oswaldo Osório; "Virgens loucas", de António Aurélio Gonçalves que comporão a base masculina do corpus. Das escritoras, abordaremos os contos "Destino de um Criol" e "Promessa", de Ivone Aida; "Forçadamente mulher, forçosamente mãe", "Um ilegítimo desejo", "Foram as dores que o mataram", "Tabus em saldo", "Álcool na noite" e "A oportunidade do grito", de Dina Salústio; "Toia" e "Vigília”, de Maria Margarida Mascarenhas; "O suicídio de Quina", de Camila Mont-Rond.

Eventualmente, poemas de Eugénio Tavares ("Perdida"), Jorge Barbosa ("Meninas portuárias"), Vera Duarte ("Violência") e trechos de crônicas de Fátima Bettencourt (extraídas de Um certo olhar) dialogarão, em epígrafe ou contraponto, com a base ficcional, no sentido de dar a medida da extensão com que a literatura aborda as questões relativas à situação social das mulheres cabo-verdianas ao logo da história da ex-colônia à jovem nação.

Para melhor compreender os dados obtidos em análise e interpretá-los, é fundamental buscar apoio no contexto histórico em que se descortina o cenário das lutas travadas pela sobrevivência dos ilhéus e especialmente, o cotidiano da mulher crioula, sua condição socioeconômica e sua luta para superação das desigualdades de gênero.

A proposta desta pesquisa buscará ainda colocar em destaque o tema da prostituição feminina, da violência contra as mulheres e da discriminação social das personagens femininas.

Conforme propõe Vera Duarte (2007.p. 95): “Acabamos de terminar um século - e com ele o milênio - durante o qual se assistiu aos maiores triunfos, mas também aos maiores atropelos às causas da humanidade."

Assim, Investigar, por meio da realização de leituras de diversos textos literários cabo-verdianos de autoria masculina e feminina, fatores sociais relevantes ao comportamento das personagens femininas da década de trinta do século XX até os dias atuais, evidenciando a trajetória das mulheres cabo-verdianas na luta pela sobrevivência e pela construção do país, especialmente em períodos 
economicamente difíceis pelos quais atravessou o arquipélago, parece-nos relevante.

Os textos serão analisados à luz dos procedimentos de exclusão e das discriminações sofridas pelas personagens femininas mediante a ideologia da sociedade patriarcal em que estão inseridas e ainda sob a ótica do universo feminino, a hermenêutica de seu cotidiano e suas relações com a sociedade caboverdiana, de modo a compreender a luta das mulheres pela sobrevivência em um contexto no qual são posicionadas socialmente à margem, embora tenham fundamental papel na transmissão e preservação da cultura crioula.

Os perfis das personagens literárias femininas serão cotejados com os perfis sociais de mulheres cabo-verdianas no contexto das respectivas ilhas (espaços) e nos tempos em que se desenrolam as narrativas.

Como estratégia teórico-metodológica, a pesquisa busca estabelecer diversas relações, envolvendo simultaneamente a História, a Antropologia, a Sociologia e os Estudos Literários, de modo a examinar as relações entre o contexto histórico em que as obras estejam inseridas e os perfis das personagens femininas recortados, sempre sob a perspectiva dos estudos de gênero e do cotidiano feminino.

Para tanto, recorreremos a aportes estabelecidos por historiadores e teóricos da cultura cabo-verdiana, como Maria Emília Madeira Santos, António Carreira e Manuel Brito-Semedo, que abordam questões relativas à(s) identidade(s) cabo-verdiana(s); Pedro Cardoso, João Lopes Filho e Manuel Ferreira, que iluminarão temas do cotidiano cabo-verdiano e, com Benjamin Abdala Júnior, Luís Manuel de Sousa Peixeira e Gabriel Mariano nos fornecerão subsídios para ancorar nosso estudo na investigação de aspectos do processo de formação da cultura crioula e da literatura do arquipélago sob o signo do hibridismo. Manuel Veiga nos conduzirá pelas trilhas literárias, culturais e simbólicas relativas à insularidade caboverdiana.

No que diz respeito à escritura feminina e às relações de gênero, a leitura de Cabo Verde Literatura em Chão de Cultura, de Simone Caputo Gomes, principalmente, dará impulso ao nosso trabalho com a literatura e a sociedade caboverdianas, permitindo que nos posicionemos quanto às transformações da série literária e à importância das questões levantadas nas obras de autoria feminina face às representações expostas em textos de autoria masculina. 
Maria Odila Leite da Silva Dias, com o texto "Novas Subjetividades na Pesquisa Histórica Feminista: uma hermenêutica das diferenças", constituirá nosso apoio teórico principal para a abordagem do cotidiano feminino e Neuma Aguiar, com Gênero e Ciências - desafio às ciências desde a perspectiva das mulheres, entre outras obras, permitirá que examinemos como se dá a desconstrução da concepção machista de gênero, aplicando-a ao contexto caboverdiano.

Serão examinados ainda documentos que elucidam questões pertinentes às Leis dos Direitos Humanos, às questões de gênero no milênio, às formas de discriminação das mulheres nas sociedades patriarcais e, em especial, Cabo Verde.

Seguem a estas considerações introdutórias que delimitam o tema, justificam nossa escolha, a metodologia e os principais aportes críticos da dissertação, os seguintes capítulos do trabalho: 1. Abordagem de gênero e hermenêutica do cotidiano: breves reflexões teóricas sobre a representação social das mulheres, que fundamentarão a leitura, como conjunto de conceitos e categorias bastante rentáveis para a análise dos textos cabo-verdianos selecionados; 2. A construção da história das mulheres cabo-verdianas: vencendo barreiras, que tratará os dados contextuais relativos ao solo onde se inserem as histórias (a História) de exclusão social e discriminação das mulheres cabo-verdianas, com destaque para os temas da prostituição, pedofilia, maternidade precoce e violência que lhes retardam a emancipação e a conquista da igualdade de direitos. O capítulo 3, Literatura e representação social das mulheres em Cabo Verde, vai debruçar-se sobre os textos literários selecionados para o corpus, buscando verificar como a produção masculina apresenta as mulheres caboverdianas e como elas se revelam a si próprias na produção de autoria feminina. As considerações finais e o repertório bibliográfico concluem esta etapa da pesquisa, que se pretende retomar e aprofundar num futuro. Os anexos incorporados à dissertação, sob a forma de telas de representativos artistas cabo-verdianos, funcionarão apenas como ilustrativos de problemáticas a examinar. 


\title{
CAPÍTULO 1
}

\section{ABORDAGEM DE GÊNERO E HERMENÊUTICA DO COTIDIANO: BREVES REFLEXÕES TEÓRICAS SOBRE A REPRESENTAÇÃO SOCIAL DAS MULHERES}

\author{
Tempos novos \\ ideais recuperados \\ brilho no ar e transparência em tudo \\ serão espelho \\ onde se refletirá \\ a imagem \\ diferente e subversiva \\ da mulher de hoje \\ a ganhar forma \\ a ganhar corpo \\ a crescer \\ a VIVER
}

\section{Vera Duarte}

Pensar sobre a historicidade das ações das mulheres é recuar no tempo em busca de compreender a sua trajetória e a história das lutas femininas por emancipação social e discursiva.

Relembrando asserção de Virginia Woolf, em Um teto todo seu,

[...] qualquer mulher nascida com grande talento no século 16 teria certamente enlouquecido, ter-se-ia matado com um tiro, ou terminado seus dias em algum chalé isolado, fora da cidade, meio bruxa, meio feiticeira, temida e ridicularizada (2004, p. 62).

Entre os séculos XV e XVII, o mundo começa a ter conhecimento das ações de alguns grupos de mulheres resistentes às imposições determinadas, principalmente, pela Igreja, e, como resposta a essas transgressões, a Inquisição as queima, sob a acusação de praticarem rituais de bruxaria.

Estigmatizadas, perseguidas, muitas delas exiladas ou mortas por almejar a liberdade do gênero, na busca incessante de fazerem ouvir suas vozes, na tentativa 
de se posicionarem diante da mentalidade androcêntrica que imperava, as mulheres vão pouco a pouco conquistando etapas no intuito de rasurar a ordem que persistia em silenciá-las e inferiorizá-las.

Em 1857, o mundo presencia uma das piores crueldades aplicadas às mulheres nos Estados Unidos: 129 operárias de uma indústria têxtil são assassinadas pelos patrões, por haverem planejado uma greve reivindicando melhores condições de trabalho, redução de uma jornada diária que atingia 14 horas diárias de trabalho em linhas de produção, caracterizando-se como mais um tipo de escravatura.

Cinquenta e três anos depois (1910), em Copenhague, Dinamarca, acontecia $02^{\circ}$ Congresso Internacional de Mulheres em memória das operárias mortas durante o protesto de 1857. Em minoria social, as mulheres começam a ampliar sua luta política e transformam o feminismo em movimento social, em busca de novas aliadas (e aliados) nas áreas socioeconômica, política e cultural, atuando em um contexto masculino que Ihes nega direito, inclusive, à liberdade de expressão.

As lutas feministas prosseguem a passos lentos, mas decisivos, dos quais apontaremos alguns marcos importantes.

Na França, em 1949, eclode um ensaio literário intitulado O Segundo sexo, de Simone Beauvoir, que promove um salto para na visão de mundo com relação ao feminino. A sociedade francesa, que antes sofrera um golpe moral com a novela de Gustave Flaubert, Madame Bovary (1857). Noventa e dois anos depois, a França assiste a um novo escândalo literário, incitado pela obra de Beauvoir, que repercutiu no mundo, contribuindo sobremaneira para a emancipação da mulher contemporânea, a partir de uma frase célebre, em que põe em foco o historicismo da ação das mulheres e o caráter social do conceito de gênero: "Não se nasce mulher, torna-se".

Rachel Soihet (1998, p. 99) lembra que Mary Nash remonta à década de quarenta, por iniciativa da historiadora norte-americana Mary Beard, em sua obra Woman as Force in History, a abordagem da questão da marginalização das mulheres nos estudos históricos. A causa, segundo Beard, seria o fato de a grande maioria de historiadores ser, até então, do gênero masculino e, por isso, limitando-se a registrar o protagonismo dos homens, cerceando os mecanismos que permitiam visibilidade às ações femininas e reduzindo as vozes de mulheres ao silêncio. 
A palavra de ordem, desde a década de sessenta, foi a luta pela igualdade de direitos e oportunidades entre os gêneros, focada, no caso das mulheres, contra a ideologia machista que Ihes impunha a condição de objeto, na desconstrução de constructos alicerçados na inferiorização das mulheres pelos homens.

Rachel Soihet (1997, online, p. 24) destaca a importância do enfoque na vida cotidiana para a inclusão das mulheres na História e a conseqüente valorização de sua participação,

[...] um movimento iniciado na historiografia na década de 1930 e que abre possibilidades para novas formas de se considerar o papel da urgência humana nos processos de transformação social, enquanto simultaneamente busca uma ênfase nos sujeitos concretos, em lugar de idealizações abstratas. Isto introduz um novo relativismo na análise, dando margem à integração da experiência das mulheres na História.

A análise dos enfoques feministas da História, realizada por Soihet (Ibidem), começa por discutir os pressupostos de um pretenso universalismo das análises que preconizam a existência de um sujeito da História, incapaz de estabelecer a diferença entre feminino e masculino. As periodizações tradicionais da História

[...] não funcionam se as mulheres são levadas em conta. As experiências de inclusão das mulheres trazem à tona as dificuldades conceituais, fragmentando as identidades coletivas, concedendo destaque às diferenças entre homens e mulheres, em favor da transitoriedade dos valores, em lugar de sua generalização.

Complementado as reflexões de Soihet, Maria Odila Leite da Silva Dias (1994, p.373) considera:

Não há por que considerar a oposição masculino-feminino tal como se apresenta hoje, com uma carga de definições culturais herdadas do passado, como se fosse necessária ou inata. O estudo das relações de gênero caminha no sentido de documentar as diferenças culturais, de nuançá-las de modo que um dia, eventualmente transformadas, possam se aproximar: neste momento, em vez de destacar-se em contornos de nitidez cultural desnecessária, estarão provavelmente nuançadas em uma multiplicidade de diferenças que não somos capazes de ver hoje.

Rosiska Darcy de Oliveira (1993, p. 109) acrescenta: 
A revalorização da diferença não tem por que enfraquecer a luta pela igualdade, mas deve, certamente, redefini-la. [...] o projeto da diferença é pós-feminista, não porque nega ou contradiz o projeto de igualdade, mas porque corrige suas distorções.

As categorias bipolares superpostas ao binômio masculino-feminino _ cultura/natureza, público/privado, macro e micro _ não dão conta da variedade de experiências de vida das mulheres. Os constructos teóricos que empregam essas categorias bipolares também costumam priorizar a família, a reprodução ou o parentesco, definindo as mulheres por suas funções biológicas e não por seus lugares sociais.

Maria Odila Silva Dias (1998, p. 231), aliando a hermenêutica do cotidiano ao feminismo (e ao estudo das condições de vida dos oprimidos, dando voz aos "silenciados da história" e visibilidade às novas subjetividades emergentes), explicita:

A hermenêutica do cotidiano nas ciências humanas parte, atualmente, de um enfoque de crítica da cultura e da metafísica tradicional, que consiste no esforço de transcender dualidades como sujeito-objeto, natureza-cultura, concreto-abstrato.

Margareth Rago (1998, p. 31), sobre a rasura das argumentações positivistas e da história narrada pelas elites, esclarece:

[...] não há como fugir ao fato de que todas as minorias relativamente organizadas, e não apenas as mulheres, estão reivindicando uma fatia do bolo da ciência e que nenhum dos grupos excluídos, negros, africanos, orientais, homossexuais, mulheres, com suas propostas de epistemologias alternativas - feminista, terceiro mundista, homossexual, operária - pode hoje reivindicar um lugar de hegemonia absoluta na interpretação do mundo. Além disso, há que se reconhecer às dimensões positivas da quebra das concepções absolutizadoras, totalizadoras, que até recentemente poucos percebiam como autoritárias, impositivas e hierarquizantes. Não há dúvidas de que o modo feminista de pensar rompe com os modelos hierárquicos de funcionamento da ciência e com vários dos pressupostos da pesquisa científica. [...] é possível dizer que as mulheres estão construindo uma linguagem nova, criando seus argumentos a partir de suas próprias premissas (grifos nossos).

Rachel Soihet (1997, p. 25) propõe, então, que se utilize a categoria "gênero" para dar visibilidade à historicidade feminina ou para propor uma releitura da história no feminino, pelas possibilidades teóricas que o conceito oferece para rever e, consequentemente, mudar os paradigmas históricos existentes, observando, 
todavia, que a abordagem representa ainda um desafio para a discussão de temas como a guerra, a diplomacia e o poder político estatal, uma vez que a análise de gênero tem se restringido às relações entre homens e mulheres no âmbito da família e de relações sociais que ainda não atingem patamares maiores do poder.

Termo utilizado desde a década de setenta, para teorizar o caráter social das distinções baseadas no sexo, para Joan Scott (1990, p. 5) "indicava uma rejeição ao determinismo biológico implícito no uso de termos como 'sexo' ou 'diferença sexual'. O 'gênero' sublinhava também o aspecto relacional das definições normativas de feminilidade", introduzindo a noção de 'relação' no vocabulário analítico e desmistificando estereótipos.

Ao processo de construção das relações de gênero, Scott (1990, p. 15), recorrendo a Foucault, acrescenta uma segunda proposição que diz respeito à pertinência do gênero como categoria de compreensão e explicação histórica de outras relações de poder:

O gênero é uma das referências recorrentes pelas quais o poder político tem sido concebido, legitimado e criticado. Ele não apenas faz referência ao significado da oposição entre homem e mulher; ele também o estabelece. Para proteger o poder político, a referência deve parecer certa e fixa, fora de toda construção humana, parte da ordem natural ou divina.

O aspecto essencial do gênero, como formulado por Scott, é expor as estratégias de dominação que sustentam a construção binária da diferença entre os dois sexos. O conhecimento de gênero assume-se como um saber relativo, cujos usos e significados advêm de uma disputa política. Para Scott:

O termo "gênero" torna-se, antes, uma maneira de indicar "construções culturais" - a criação inteiramente social de idéias sobre papéis adequados aos homens e às mulheres. Trata-se de uma forma de se referir às origens exclusivamente sociais das identidades subjetivas de homens e de mulheres. "Gênero" é, segundo essa definição, uma categoria social imposta sobre um corpo sexuado. Com a proliferação dos estudos sobre sexo e sexualidade, "gênero" tornou-se uma palavra particularmente útil, pois oferece um meio de distinguir a prática sexual dos papéis sexuais atribuídos às mulheres e aos homens (lbidem)

Louise Tilly (1994), assim como Scott, defende o uso do gênero como categoria útil de análise, para colocar em xeque os conceitos dominantes da 
disciplina histórica. A partir do conceito de gênero emerge um novo campo legítimo de conhecimento acadêmico, a Teoria das Relações de Gênero como uma nova maneira de encarar os processos históricos, baseada na luta política mais ampla, no campo das negociações (simbólicas) culturais.

A palavra gênero passou a ser usada no interior dos debates que se travaram dentro do próprio movimento feminista, à busca de uma explicação para a subordinação das mulheres à dominação dos homens, com apoio da multidisciplinaridade. Para explicar as diferentes formas de subordinação, a categoria "Mulher" (homogênea e unificadora de experiências ou indiciadora de uma condição) também se mostrou insuficiente, passando o pós-feminismo a utilizar a designação "mulheres", ao invés de Mulher como gênero universal, respeitando-se o pressuposto das múltiplas diferenças que se observavam dentro da diferença, posto que as explicações para as subordinações não seriam as mesmas para todas as mulheres, e nem aceitas por todas. As experiências variam de acordo com as culturas, os grupos sociais e o tempo, já que o corpo não determina univocamente como a divisão social será definida.

Os estudos de gênero consagram o trabalho com as categorias da diferença e do local como base para a compreensão do funcionamento da sociedade, ao invés dos princípios universais. A etnografia e o conhecimento dos elementos locais são analisados como suporte para o acesso ao outro, sua cultura, sua raça, religião etc.

Maria Odila Leite Dias lança mão da hermenêutica do cotidiano para "historicizar aspectos concretos da vida de todos os dias dos seres humanos homens e mulheres - em sociedade" (DIAS, 1994, p. 373-374) e alia-a à epistemologia feminista, acrescentando:

Na epistemologia feminista sujeito e objeto estão diluídos um no outro. A Hermenêutica apreende o sujeito como parte do mundo e não o mundo do sujeito, de modo que desvenda a possibilidade de novas formas de apreensão da subjetividade feminina em outras épocas do passado... Os estudos feministas propõem uma redefinição dos processos de subjetividade, uma crítica ao conceito de identidade, assim como ao conceito da própria racionalidade no mundo contemporâneo, que se volta para o passado a fim de se reencontrar, devidamente relativizada no presente.

Assim, a emergência da história das mulheres teve papel fundamental na desmitificação das correntes historiográficas herdeiras do iluminismo, que 
acreditavam estarem informadas pela Verdade e pela imparcialidade em suas considerações fundadas em estereótipos universais sobre o feminino, acabando por eliminar as mulheres do registro histórico.

Como bem ressalta Maria Odila (DIAS, 1992, p. 39),

[...] sujeito humano universal, verdade, razão, esquemas globalizantes deixavam de se constituir em axiomas, em favor da historicidade e da transitoriedade do conhecimento dos valores culturais em processo de transformação no tempo. Igualmente, temporalidades múltiplas, focalizando conjunturas provisórias e relativas a seu próprio tempo, substituíam a linearidade evolutiva de um processo histórico nacional e universal.

Para Margareth Rago (1998, p. 95):

Mais do que a inclusão das mulheres no discurso histórico, trata-se, então, de encontrar as categorias adequadas para conhecer os mundos femininos, para falar das práticas das mulheres no passado e no presente e para propor novas possíveis interpretações inimagináveis na ótica masculina. Mais recentemente, a discussão se volta para os próprios homens, também eles excluídos dos campos históricos em benefício da figura ficcional do Homem, construído à imagem de Deus.

Deixando de lado a polêmica relativa à divisão de espaços que os estudos da masculinidade colocam, não há dúvida de que também os homens se descobrem profundamente estrangeiros para si mesmos, ocultos que estavam numa interpretação que os elevava à categoria de deuses.

Rachel Soihet, a respeito da discussão, complementa que (1998, p. 95) "o descrédito das correntes historiográficas polarizadas para um sujeito humano universal constituiu-se num dos mais importantes ganhos na atuação das historiadoras feministas".

Além disto, vale frisar que o conceito de 'gênero' foi proposto por historiadoras que acreditavam que a pesquisa sobre as mulheres transformaria fundamentalmente os paradigmas da disciplina; acrescentando não somente "novos" temas (diríamos, novas visões dos temas) como a bruxaria, a prostituição, a loucura, o trabalho doméstico, a história das emoções e dos sentimentos (cf RAGO, 1998, p. 34-35), e também impondo uma reavaliação crítica das premissas dos constructos científicos existentes, implicando não apenas uma nova história das mulheres, mas uma nova História. 
Na construção dessa nova História, e face à "insuficiência dos corpos teóricos existentes para explicar a persistência da desigualdade entre mulheres e homens" (MATOS, 1997, p. 80), tornava-se fundamental a articulação da categoria gênero com outras categorias, como classe e raça (SOIHET, 1998, p. 101). O interesse por essas categorias assinalou o compromisso dos historiadores com a inclusão da fala dos oprimidos, considerando que "as desigualdades de poder se organizam, no mínimo, conforme estes três eixos" (Ibidem).

A história contada no feminino tem recorrido ainda à abordagem do cotidiano, que permite o reencontro dos tempos desiguais e simultâneos no espaço do vivido e das resistências possíveis de fazer face à visão da história "miserabilista" (PERROT, 1987 apud SOIHET, 1998, p. 100), na qual se sucediam "mulheres espancadas, enganadas, humilhadas, violentadas, sub-remuneradas, abandonadas, loucas e enfermas"... A hermenêutica do cotidiano das mulheres permitiu emergir o perfil da mulher rebelde (lbidem), dando destaque a contradiscursos construídos no domínio do miúdo e do detalhe (RAGO, 1998, p. 23). Algumas abordagens sobre as mulheres nos segmentos populares realizadas por Michelle Perrot (Os excluídos da História - operários, mulheres, prisioneiros, 1988) e Natalie Zemon Davis (Culturas do povo: sociedade e cultura no início da França moderna, 1990) destacam o perfil da mulher atuante e transformadora de sua história a partir de seu cotidiano.

No entanto, fazem-se necessários enfoques que permitam superar a dicotomia vitimização x sucessos femininos, de modo a abarcar a complexidade da atuação das mulheres. Tais preocupações convergem para a utilização da categoria de gênero para a análise da diferença sexual, acompanhada da revisão e expansão dos campos de pesquisa histórica.

Historiadoras como Michelle Perrot, Natalie Davis, Arlette Farge, Maria Odila da Silva Dias têm se baseado nessas linhas de análise, no esforço de reconstrução da atuação feminina. Alinhando-se com Silva Dias, Rachel Soihet (1998, p.108) considera que

[...] a abertura dos historiadores para os papéis informais, visíveis apenas através do enfoque do cotidiano, constitui-se no recurso possível para o atingir de nosso objetivo; qual seja, o de obter pistas que possibilitem a reconstrução da experiência concreta das mulheres em sociedade, que têm desempenhado um papel ativo na 
criação de sua própria história. Dessa forma interpenetram-se, num processo dialético, a história das mulheres e uma nova História.

Com o questionamento das normas e papéis preestabelecidos, as mulheres passam a construir um contradiscurso que coloca "face a face [...] duas visões de mundo", introduzindo "a incerteza, a pluralidade e a escolha onde anteriormente só havia certeza, unanimidade e conformidade" (OLIVEIRA, 1993, p. 72).

Pautado pelas postulações acima expostos, o pós-feminismo examinará as fissuras à dominação patriarcal, por intermédio de estratégias de resistência geradas com a "reapropriação" e o "desvio" dos instrumentos simbólicos do dominador, como, por exemplo, a "linguagem da dominação" (Ibidem, p. 107).

Ademais, como ressalta Félix Guattari (1996, p. 73), o feminismo não coloca apenas "o problema do reconhecimento dos direitos da mulher [...]. Ele é portador de um devir feminino que diz respeito [...] a todas as engrenagens da sociedade", ampliando sua abrangência enquanto crítica da cultura.

Assim, ao abordar o cotidiano das mulheres e suas experiências vividas como papéis informais de resistência, os estudos feministas, hoje, caminham na vanguarda crítica das Ciências Humanas e a "crítica feminista torna-se contextual, histórica e relativista" (DIAS, 1994, p. 375).

Por todo o exposto, buscaremos confrontar a escrita literária cabo-verdiana produzida por mulheres ao mundo construído pelos homens e aos discursos por eles utilizados para representá-las, com o intento de, por meio da estratégia comparatista, documentar diferenças e demonstrar como as mulheres se falam, se desvelam e se revelam em Cabo Verde, a caminho de atuação efetiva e, sobretudo, reconhecida. 


\section{CAPÍTULO 2}

\section{A CONSTRUÇÃO DA HISTÓRIA DAS MULHERES CABO- VERDIANAS: VENCENDO BARREIRAS}

Uma mulher livre dos últimos focos de opressão que ainda teimam em não a deixar (...) é uma prioridade assumida pelo Governo.

José Maria Neves, Primeiro-Ministro de Cabo Verde

\subsection{MULHERES CABO-VERDIANAS, EXCLUSÃO E DISCRIMINAÇÃO SOCIAL}

Mulher é a parte fraca.

António Aurélio Gonçalves

Considerando que há dois modos básicos de construir conhecimento - um mais vocacionado para a elaboração teórica e outro para a reflexão sobre a realidade e a sua transformação, escolhemos esta linha para abordagem do discurso literário em Cabo Verde, nesta recortando o núcleo temático da exclusão social e das formas de discriminação das mulheres.

O conjunto de reflexões que apresentaremos baseia-se em documentação de origem acadêmica (referente à teoria da literatura e a áreas humanas correlatas, como sociologia e antropologia), governamental e de instituições internacionais em permanente contacto com a realidade dos excluídos em Cabo Verde e, em especial, das mulheres, na sua trajetória de submissão, conscientização, promoção, qualificação e emancipação.

Cabo Verde tornou-se parte, em 5 de Dezembro de 1980, do Comitê sobre a Eliminação da Discriminação contra as Mulheres, em decorrência da Convenção de 1979, sobre a Eliminação de Todas as Formas de Discriminação contra as Mulheres, uma das primeiras convenções de proteção aos direitos humanos ratificadas pelo Estado de Cabo Verde. 
Esse processo continuou a ser alimentado nas décadas de oitenta e noventa, metamorfoseando-se de acordo com os desafios, configurando-se hoje como uma prioridade assumida pelo Governo daquela república.

A promoção das mulheres, de sua cidadania, igualdade e dignidade fazem parte de uma meta que, não obstante em andamento, já demonstra resultados eficientes. Estratégias e políticas públicas de emancipação econômica das mulheres, especialmente as que vivem no ambiente rural e nas periferias urbanas, apoio e promoção das mulheres chefes-de-família, que lutam sozinhas para criar os seus filhos e fornecer-Ihes educação adequada, combate à violência doméstica contra as mulheres, têm sido prioridades cabo-verdianas para eliminar as diversas formas de discriminação que têm feito parte do cotidiano feminino desde os tempos coloniais e que persistem nos dias atuais.

Para tanto, o Governo de Cabo Verde elaborou um Plano Nacional para a Igualdade e Equidade de Gênero (2005-2009), no sentido de avançar no cumprimento do objetivo de garantir os direitos das mulheres em Cabo Verde.

Na sua Parte I, artigo 1ㅜ, a Convenção sobre a Eliminação de Todas as Formas de Discriminação contra as Mulheres (CEDAW, 2007, p. 22) assim define "discriminação":

[...] qualquer distinção, exclusão ou restrição baseada no sexo que tenha como efeito ou como objectivo comprometer ou invalidar o reconhecimento, o gozo ou o exercício pelas mulheres, seja qual for o seu estado civil, com base na igualdade dos homens e das mulheres, dos direitos humanos e das liberdades fundamentais nos domínios político, económico, social, cultural e civil ou em qualquer outro domínio.

Em seu artigo 3o, a Convenção (Ibidem, p. 23) complementa:

Os Estados Partes devem tomar, em todos os domínios, nomeadamente no político, social, económico e cultural, todas as medidas apropriadas, incluindo disposições legislativas, para assegurar o pleno desenvolvimento e o progresso das mulheres, com vista a garantir-lhes o exercício e o gozo dos direitos humanos e das liberdades fundamentais, numa base de igualdade com os homens

Os artigos 4 e 5o ressaltam a necessidade de que os Estados Partes tomem as medidas apropriadas para: modificar o padrão de comportamento social e cultural 
dos homens e das mulheres, com vista a alcançar a eliminação dos preconceitos e das práticas que se fundem na idéia de inferioridade de um dos sexos ou de papéis estereotipados dos homens e das mulheres; e ainda assegurar que a educação familiar inclua o entendimento da maternidade como uma função social e o reconhecimento da responsabilidade comum dos homens e das mulheres na educação e desenvolvimento dos filhos (Ibidem, p. 24).

Todas as formas de tráfico de mulheres e de exploração da prostituição das mulheres são objeto do artigo $6^{\circ}$ da Convenção, enfatizando-se a premência da eliminação dessas práticas (Ibidem, p. 25).

A República de Cabo Verde emprega medidas legais, administrativas e educativas para eliminar todas as formas de discriminação contra as mulheres e assim busca proteger os seus direitos e interesses específicos. Como mestres de suas próprias consciências, as mulheres cabo-verdianas têm participado cada vez mais ativamente do desenvolvimento nacional e têm prestado importantes contribuições na área da indústria e agricultura, ciência, cultura, educação e saúde pública. Simultaneamente, as mulheres têm adquirido um censo de respeito próprio, autoconfiança, auto-estima, que tem contribuído para capacitá-las a fazer substanciais progressos naqueles campos. É claro que a discriminação contra as mulheres, e mesmo a violação de seus interesses e direitos, não são incomuns, e muitos dos talentos e habilidades das mulheres cabo-verdianas precisam ser fortalecidos.

A República de Cabo Verde tem se dedicado ao desenvolvimento econômico, ao fortalecimento do sistema jurídico, buscando eliminar todas as idéias de discriminação contra as mulheres na sociedade, pretendendo cumprir, por conseguinte, com os objetivos estratégicos da Declaração de Beijing e da Plataforma de Ação adotada na IV Conferência Mundial sobre as Mulheres.

Numa análise da situação nacional, segundo o último Censo realizado em 2000, a população residente no arquipélago de Cabo Verde era de 434.625 habitantes (hoje é estimada em 500 000), dos quais 223.995 eram mulheres, representando $51,53 \%$ da população. Existiam, segundo o Censo de 2000, aproximadamente 93.975 famílias (as últimas estimativas do Instituto Nacional de Estatísticas, INE, davam ao país 499.796 habitantes em 2008, numa proporção de 241.914 homens e 257.882 mulheres). Desse total, aproximadamente 40,1\% são chefiadas por mulheres. Além disso, dentre as mulheres chefes de família, segundo 
o Censo 2000, 21,9\% vivem da exploração do trabalho agrícola ou da pesca, aproximadamente $39,9 \%$, de atividade qualificada ou semiqualificada e aproximadamente $38,2 \%$, do trabalho não qualificado.

Relativamente ao local em que vive a população, aproximadamente $53,8 \%$ vive no meio urbano e $46,2 \%$ no meio rural. A mulher é maioria, tanto no meio rural quanto no meio urbano. Segundo o Censo $2000,51,5 \%$ da população que vive no meio urbano é feminina, e no meio rural as mulheres perfazem $52,1 \%$.

No que toca à educação, segundo o Censo 2000, as mulheres que vivem no meio urbano na República de Cabo Verde e que completam cerca de onze (11) anos de escolaridade (estudos secundários) correspondem a aproximadamente 22,3\% das mulheres que ingressam no sistema escolar; $53,8 \%$ completam a sua educação no ensino básico integrado e aproximadamente $14,2 \%$ são analfabetas ou semianalfabetas. Os números correspondentes às mulheres rurais são os seguintes $7,34 \%, 54,4 \%, 29,8 \%$, respectivamente. A taxa de analfabetismo geral, no Censo de 2000 , era de $25,2 \%$ (em 2009, $17 \%$ ), sendo que a taxa de analfabetismo entre as mulheres era de $32,8 \%$.

Em Cabo Verde, as mulheres são identificadas como as principais vítimas da pobreza, em particular as mulheres chefes de família, desempregadas e com baixo nível de instrução. Por este motivo, e não somente, torna-se fundamental garantirIhes direito à educação, qualificação para o trabalho e promoção.

Carlos Sangreman Proença (2009) busca o estudo de Clark, J. (1991) sobre as ONG para considerar que essas instituições defendem um conceito de desenvolvimento com sete componentes: infra-estruturas, crescimento econômico, alívio da pobreza, equidade, ambiente, democracia e justiça social.

Retratando a pobreza atual em Cabo Verde, Proença revela que sua incidência é maior quando o chefe de família é mulher e a influência da educação na determinação da pobreza é significativa; as ilhas de Santo Antão e Fogo (predominantemente agrícolas) apresentam a maior incidência de pobreza; e esta aumenta com a dimensão da família; há maior propensão à pobreza entre os trabalhadores não qualificados, e entre os qualificados da agricultura e da pesca (domínios bastante povoados por mulheres).

Para contornar a falta de recursos, os cabo-verdianos recorrem a estratégias como a emigração (para o exterior) ou a migração para zonas urbanas (para a capital Praia, por exemplo), o recurso ao trabalho nas FAIMO (Frentes de Alta 
Intensidade de Mão de Obra), o mercado informal, as remessas das famílias do exterior e a criação de associações de desenvolvimento comunitário.

As FAIMO têm constituído a principal rede de segurança dos pobres no mundo rural, pois que nos últimos 265 anos houve 97 anos de seca, ou seja, uma média de uma (1) seca a cada três (3) anos. Das secas registradas, quatorze duraram três anos ou mais e o trabalho das FAIMO (média de 16000 - 17000 pessoas/ano diretamente e 50000 - 80000 indiretamente) teve um papel fundamental para evitar que as crises de produção agrícola tivessem conseqüências mais graves na taxa de mortalidade e na saúde geral da população.

O setor informal assume um papel importante no emprego em Cabo Verde. Um traço marcante é a ausência de contratação formal de trabalho. Nos centros urbanos, o setor informal compõe-se de pequenas empresas privadas, de caráter familiar, essencialmente no setor dos serviços, empregando pessoal pouco qualificado. Estima-se que o setor informal represente $40 \%$ do emprego total. $O$ comércio é a atividade econômica dominante, com aproximadamente $56 \%$ de todas as empresas, seguido da restauração e da hotelaria com cerca de 19\%. A pecuária de subsistência assume um papel significativo na economia rural, constituindo, tradicionalmente, um fator de segurança relativamente às crises de seca. Nos meios urbanos, o desenvolvimento da atividade informal constitui a principal saída para muitas famílias. Neste domínio, as mulheres desempenham um papel de relevo, o que explica que a incidência da pobreza feminina tenha melhorado seus índices ao longo da década de 90.

As associações comunitárias rurais, em conjunto com as ONGs, também têm procurado desenvolver ações, nos seguintes campos, segundo Carlos Sangreman Proença (2009):

[...] desenvolvimento rural integrado, saúde, saneamento, proteção e conservação do ambiente, conservação e abastecimento de água, promoção da mulher, em especial daquela que é chefe de família, proteção materno-infantil, apoio às crianças e aos jovens bem como à terceira idade, direitos humanos, construção de infraestruturas comunitárias.

No que respeita à questão de gênero, a Carta Magna de 1980 já previa, no seu artigo 26.. , que "o homem e a mulher são iguais perante a lei em todos os planos da vida política, econômica, social e cultural". 
Desde 1981, a Organização das Mulheres de Cabo Verde, OMCV, vem atuando no quadro da promoção da igualdade de gênero, contribuindo para a eliminação de todas as formas de discriminação e violência contra as mulheres, auxiliando-as na luta pela independência econômica, social e cultural em todas as ilhas do país. Atualmente, há pelo menos 6 organizações de mulheres no país, trabalhando em áreas específicas: Associação de Apoio à Auto-Promoção da Mulher no Desenvolvimento (MORABI), Associação Cabo-verdiana de Mulheres Juristas (AMJ), Organização das Mulheres de Cabo Verde (OMCV), Associação das Mulheres Empresárias de Cabo Verde, Rede de Mulheres Parlamentares, Rede das Mulheres Economistas de Cabo Verde. Além disso, existem mais de três dezenas de instituições da sociedade civil, espalhadas nas diversas ilhas, que promovem ações procurando priorizar as mulheres.

Em 1994 foi criado o Instituto da Condição Feminina (ICF, atualmente designado como chamar "Instituto Cabo-verdiano para a Igualdade e Equidade de Gênero" ou ICIEG) pelo Decreto-Lei n. ${ }^{\circ}$ 1/94, de 10 de Janeiro, destinado a intervir nas questões relativas às mulheres, para garantir-lhes o exercício efetivo da igualdade de direitos, oportunidades e dignidade, assim como favorecer a integração plena da mulher no desenvolvimento nacional e em todos os domínios e níveis da vida familiar, profissional, cultural, econômica e política.

Atuando até o presente momento, este Instituto promoveu, em 1996/2000, o Plano de Ação Nacional para a Promoção da Mulher, estendendo a abordagem de gênero a um nível de planificação global e criando grupos de seguimento e avaliação da implementação da abordagem de gênero nos setores governamentais (Inquérito Demográfico da Saúde Reprodutiva, 1998, e preparação do Recenseamento Agrícola, 2000). O Instituto da Condição Feminina, com apoio de organizações não-governamentais, tem promovido ações de sensibilização na área da saúde reprodutiva, atividades geradoras de rendimento, direitos e participação, ateliers e ações de formação para a sensibilização nas questões de gênero e para a promoção de discussões sobre o papel da mulher no desenvolvimento, promoção de campanhas contra a violência doméstica, publicação de guias para a divulgação dos direitos das mulheres, brochuras ilustradas sobre o direito da família, agendas e encartes sobre planejamento familiar e gravidez na adolescência, campanhas contra a SIDA (AIDS). 
Em 2002, o Instituto da Condição Feminina realizou o trabalho de "Apoio à promoção da igualdade entre os sexos e ao reforço das capacidades das mulheres", enfocando a abordagem do gênero em diversas dimensões (social, econômica e política), buscando atingir o território nacional com a participação de quase todos os "concelhos" do país através de ações, formações, divulgações, campanhas e seminários além de visar à sensibilização para o microcrédito como primordial no combate à pobreza e à dependência econômico-financeira das mulheres.

Para a garantia dos direitos humanos das mulheres, o Governo da República de Cabo Verde criou, em 2004, um Gabinete de Acolhimento das Vítimas de Violência Doméstica. O Plano de Governo adotou também leis especiais reguladoras do trabalho doméstico e do regime de segurança social a favor das empregadas domésticas.

Em 2004 foi criada também a Comissão Nacional para os Direitos Humanos e a Cidadania, CNDHC, pelo Decreto-lei n. 38/2004 (em substituição do Comitê Nacional dos Direitos Humanos), sendo atualmente o órgão que tem dado continuidade e implementado as ações relativas a promoção e progresso das mulheres, além de atuar na área dos direitos humanos como um todo.

Nesse trajeto de busca de garantias dos direitos e de processos para dar visibilidade à importância das mulheres na sociedade cabo-verdiana, em fevereiro de 2005, por esforços conjuntos da Comissão Nacional para os Direitos Humanos e a Cidadania, de organizações não-governamentais e do governo, foi aprovado pelo Conselho de Ministros o Protocolo Adicional à Carta Africana dos Direitos do Homem e dos Povos, relativo aos Direitos da Mulher para ratificação pelo Parlamento. Evidenciam-se, pois, em Cabo Verde, esforços contínuos despendidos por diversos setores em prol da efetivação dos direitos das mulheres.

A promoção dos direitos das mulheres intensifica-se no campo do concreto: essas instituições tratarão a questão da mulher na saúde, na cultura, na economia e no papel social que ela desempenha na sociedade cabo-verdiana. Além da promoção de programas na mídia, vêm sendo realizadas inúmeras campanhas para progresso e desenvolvimento da mulher, visando trazer a problemática feminina para o domínio público e ressaltando a importância da definição e implementação de políticas públicas com enfoque nas mulheres.

No âmbito do Programa Nacional de Luta contra a Pobreza, o governo tem estabelecido metas como atingir um número determinado de pessoas a serem 
beneficiadas, sendo $60 \%$ deste total constituídos por mulheres. Os benefícios estão ligados às ações de alfabetização, formação profissional, construção de infraestruturas e concessão de microcréditos.

O governo da República de Cabo Verde tem procurado ainda enfrentar um dos maiores problemas cabo-verdianos, a violência no seio da família, objetivando a eliminação progressiva do estereótipo de inferioridade no que diz respeito às mulheres. Como causas dessa violência, podemos apontar a condição sócioeconômica e o "machismo" ou sentimento de superioridade do homem sobre a mulher ainda presente na sociedade cabo-verdiana, sobretudo nas classes mais desfavorecidas. Além disso, são também apontados problemas como alcoolismo, consumo de drogas, desemprego e prostituição. Desde a criação do Gabinete de Acolhimento a Vítimas de Violência Doméstica, em Julho até Dezembro de 2004 relata-se o atendimento de aproximadamente 245 mulheres (CEDAW, 2007, p. 148).

$\mathrm{Na}$ mesma trilha de enfrentamento da violência familiar, o governo da República de Cabo Verde, em janeiro de 2004, criou os Centros de Emergência Infantil na Cidade da Praia e do Mindelo, com capacidade também para atender crianças provenientes de outras ilhas, espaços de acolhimento de crianças vítimas de maus-tratos, abandono, violência, abuso sexual ou que se encontrem em outras situações consideradas de risco. Desta forma, tenta-se atender de modo mais amplo e alargado a questão da violência doméstica em que não somente as mulheres podem estar diretamente implicadas, mas também seus filhos.

Em síntese, a situação das mulheres cabo-verdianas tem melhorado paulatinamente e pode-se afirmar que o reconhecimento da função da mulher na sociedade obteve ganhos. A importância da função social das mulheres em Cabo Verde é atestada, nos dias de hoje, pela presença crescente de mulheres no poder executivo (ministérios e secretarias, direção de serviços e departamentos, câmaras municipais), no poder judiciário (tribunais e procuradorias), assim como na administração em geral e também nos órgãos legislativos (Assembléia Nacional e Assembléias Municipais). Quando o primeiro governo foi instituído, logo após a independência em 1975, não havia nenhuma mulher a dirigir um dos 10 ministérios criados. Atualmente, há 8 Ministras no Governo, e em pastas de alta importância. 


\subsection{FORMAS DA DISCRIMINAÇÃO}

Nós não iremos poupar esforços para libertar nossos semelhantes homens, mulheres e crianças das abjetas e desumanas condições de extrema pobreza nas quais mais de um bilhão de pessoas estão atualmente submetidos.

Este é o início do texto da Declaração do Milênio das Nações Unidas, de setembro de 2000. Com ela, os 191 países reunidos oficializaram a união de forças para a consecução de oito prioridades de desenvolvimento: pobreza e fome, educação primária, igualdade de gênero, mortalidade infantil, saúde materna, HIV/AIDS e outras doenças sérias, sustentabilidade ambiental e parcerias globais para o desenvolvimento.

Pelo exposto no item anterior, percebemos que os seis primeiros tocam de pronto as condições das famílias cabo-verdianas especialmente as chefiadas por mulheres. E englobam as circunstâncias de vida destas no arquipélago.

O documento do UNIFEM (Fundo de Desenvolvimento das Nações Unidas para a Mulher), com base na Declaração e reconhecendo que a desigualdade de gênero está profundamente enraizada em comportamentos, instituições sociais e forças de mercado, enfatiza:

A importância da igualdade de gênero para o desenvolvimento humano sustentável foi bem articulada nas conferências da ONU dos anos 90. Nestas conferências globais, os governos reconheceram as contribuições das mulheres ao desenvolvimento econômico e os custos suportados pelas sociedades como resultado das múltiplas desvantagens e discriminações de gênero que as mulheres enfrentam em quase todos os países. Entre os líderes mundiais, um consenso geral reconhece o papel central da igualdade de gênero para atingir todos os outros ODM (Objetivos do Milênio, http://www.unfpa.org/gender/docs/combating_gbv_por.pdf).

O Relatório do Projeto do Milênio identifica ainda, segundo o documento do UNIFEM, uma prioridade, dentre as sete estabelecidas, que urge combater: a violência contra as mulheres como uma possível ação de "rápido ganho" para acelerar o alcance dos Objetivos do Milênio. A Rede de Mulheres Africanas Ministras e Parlamentares comprometeu-se em combater a violência baseada em gênero 
(VBG) e lidera o desenvolvimento de intervenções inovadoras, incluindo: a elaboração de propostas para legislação apropriada e aumento da conscientização da comunidade sobre a violência baseada em gênero.

O Artigo 2 da Convenção de Eliminação de Todas as Formas de Discriminação Contra a Mulher (CEDAW) explica que a violência contra a mulher inclui a violência sexual, física e psicológica em:

1. família, tais como surra, abuso sexual de crianças, mutilação/corte de órgãos genitais femininos e estupro;

2. comunidade, tais como abuso sexual, assédio sexual e intimidação, tráfico e prostituição forçada; e

3. Estado, tais como leis mal escritas ou sem efeito para a violência contra a mulher, agentes reguladores que violam mulheres, a falta de instalações e educação para prevenção e tratamento de mulheres expostas à violência, a sanção e reafirmação de relações de gênero desiguais. A indiferença e a negligência do Estado em criar oportunidades e direitos para mulheres com relação a empregos, educação, participação e acesso a serviços sociais, também perpetuam a violência baseada em gênero.

Como pontuamos no item anterior, a República de Cabo Verde tem buscado atuar em todos estes segmentos, mas algumas questões seculares ainda persistem quanto às formas de discriminação.

Um dos problemas mais graves que o governo tem enfrentado refere-se à questão da violência no seio da família, decorrente da subjugação da mulher por conseqüência do estereótipo de inferioridade. Inúmeras campanhas nacionais, segundo o Relatório do CEDAW, têm sido empreendidas neste sentido, para mobilizar as mulheres sobre os seus direitos e também alertar a sociedade de que este é um problema que deve ser combatido por todos.

As causas mais prováveis apontadas para a violência doméstica em Cabo Verde são: a condição sócio-econômica e o machismo ou sentimento de superioridade do homem sobre a mulher, especialmente nas classes menos favorecidas economicamente; o alcoolismo, o consumo de drogas, o desemprego (CEDAW, p. 71).

Desde a criação do Gabinete de Acolhimento a Vítimas de Violência Doméstica, em julho de 2004, até dezembro, foram atendidas aproximadamente 245 mulheres. Seguindo esta linha, o governo da República de Cabo Verde, através do 
Instituto Cabo-verdiano de Menores, em janeiro de 2004, criou os Centros de Emergência Infantil na Cidade da Praia e do Mindelo, com capacidade para atender crianças provenientes de outras ilhas. Esses Centros são espaços de acolhimento provisório e transitório de crianças vítimas de maus-tratos, abandono, violência, abuso sexual ou que se encontrem em outras situações consideradas de risco. A estrutura abarca o atendimento psicológico, social, educacional e monitoramentos para zelar pelo bem-estar físico e psicológico das crianças sob sua responsabilidade. São acolhidas crianças entre zero a 12 anos e, eventualmente entre os 13 e 16 anos de idade (CEDAW, p. 73).

Assim, trabalhando também a questão da violência contra crianças e adolescentes no seio da família, a República de Cabo Verde tenta atender extensivamente a questão da violência doméstica, em que não somente as mulheres podem estar implicadas, mas também seus filhos.

A violência doméstica é produto de um padrão de relações assimétricas entre homem e mulher, legitimado pela ideologia patriarcal dominante e favorecido pela forma na qual a mulher se encontra sujeita aos desígnios sócio-econômicos e culturais prevalecentes, construídos a partir da concepção masculina.

O lar, em sua grande maioria, nem sempre é um espaço de proteção para mulheres e crianças. Até recentemente, a violência intrafamiliar era tratada como um assunto de caráter privado. A dicotomia entre espaço público e espaço privado com conotação hierárquica designada a cada sexo - surge como marco de análise a fim de explicar a subordinação da mulher dentro do lar. De acordo com este enfoque, a autoridade do homem estende-se a todos os níveis da vida social, pública e privada, justificando-se pela sua inserção no trabalho produtivo. Por outro, lado, à mulher se destina o espaço doméstico, restrito e controlado, colocando-a, assim, em posição de inferioridade no conjunto das relações sociais, levando-a a assumir comportamentos freqüentemente dependentes.

Frutos dessa violência expressa em vários níveis (de superioridade de gênero, psicológico, físico, econômico), a prostituição feminina (adulta e infantil), a pedofilia, a maternidade precoce e suas conseqüências (aborto, filhos sem pai, prole muito numerosa) têm recorrências no cotidiano das mulheres cabo-verdianas.

A prostituição, por exemplo, não constitui crime em Cabo Verde, mas as atividades de exploração da prostituição tipificam vários. No domínio dos crimes cometidos contra a liberdade das pessoas está o lenocínio, que consiste no 
favorecimento ou facilitação do exercício da prostituição ou prática de atos sexuais de menores de 14 anos, ou de pessoas sofrendo de incapacidade psíquica, ou de necessidade econômica extrema (CEDAW, 82). Tais temas serão representados nos contos literários que esta pesquisa se propõe a examinar em capítulo próprio.

A República de Cabo Verde, por tratar-se de um país pequeno, não tem tido graves problemas com tráfico de mulheres e prostituição forçada, mas são situações que merecem acompanhamento, pois o processo de desenvolvimento turístico em curso poderá agravar estas questões.

Um dos valores consagrados a todos os seres humanos na República de Cabo Verde é a dignidade humana, valor fundamental intangível, expressamente estabelecido no art. $1 . \stackrel{\circ}{ }, \mathrm{n} . \stackrel{\circ}{1}$, da Lei Constitucional em vigor. . Os crimes de natureza sexual em geral, como de violação e agressão sexual, são entendidos, no Código Penal atual, como crimes contra a liberdade de autonomia da pessoa humana: o tráfico de mulheres e a prostituição forçada, por exemplo, atingem a liberdade da pessoa e a sua autodeterminação sexual. Assim, segundo a legislação penal cabo-verdiana (artigo 142. ), a "agressão sexual" é um ato sexual efetivado mediante violência, coação, ameaça, fraude, colocação deliberada da vítima em situação de inconsciência ou impossibilidade de resistir ou de aproveitamento dessa mesma situação, podendo ser punido com pena de prisão (CEDAW, p.178).

A emigração clandestina em Cabo Verde tem levado sofrimento e precariedade a um número elevado de seres humanos, que embarcam nos "navios negreiros da modernidade" à procura de "terras da promissão" ou países que gozam de boa reputação, afirma Vera Duarte, que foi Presidente da Comissão Nacional de Direitos Humanos e Ministra da Educação e Ensino Superior. E acrescenta que é preciso (DUARTE, Migração clandestina e tráfico de mulheres, online):

[...] definir políticas migratórias correctas que correspondam aos interesses económicos e salvaguardem os direitos humanos; e (...) reprimir o crime transnacional organizado e o tráfico de pessoas, que fomenta as redes de imigração clandestina, aproveitando-se da vulnerabilidade das vítimas para Ihes extorquir tudo o que puderem.

Segundo Duarte, do tráfico clandestino de mulheres, homens e crianças para além das fronteiras nacionais, a maior parcela - até $80 \%$ - é constituída por mulheres e jovens. Destas, as vítimas de tráfico ou migrantes em situação irregular se dedicam essencialmente a serviços domésticos e relacionados ao sexo 
(sobretudo no Senegal, Portugal, Estados Unidos e Itália). Vários textos literários cabo-verdianos abordam a emigração da mulher ou da adolescente para Dakar, explicitando ou apenas sugerindo que levará, naquela cidade, vida de prostituta.

Por outro lado, aumenta o número de mulheres que, dos países da costa ocidental africana, imigram para Cabo Verde, para trabalhar em áreas relacionadas com o turismo, geralmente como profissionais do sexo, e como empregadas domésticas ou vendedeiras ambulantes.

Contextualizando as causas remotas dessas migrações, ressalta Vera Duarte (Ibidem):

Importa contudo não esquecer que o tráfico de mulheres para Cabo Verde começou com a própria génese da Nação, pois no seio dos escravos africanos que vieram do continente, grande parte eram mulheres, assim como grande parte do horrendo e vergonhoso tráfico negreiro dos séculos XVI a XIX foi feito com mulheres.

Não por acaso, a brasileira Esther Ferraz (1952, p.2), estendendo o campo da relação escravidão-prostituição feminina, define esta como uma nova forma de escravatura:

E, em verdade, não constituirá mero diletantismo discorrer sobre a necessidade ou conveniência de se conferir à mulher plena capacidade civil e política, quando é certo que ainda hoje [...] existe uma legião de mulheres sujeitas a um regime de autêntica escravatura? Mulheres que não se pertencem e que, como animais, são vendidas e revendidas, exploradas e maltratadas, a ponto de já haverem perdido toda a noção de dignidade humana?

Ferraz defende a ideia de que a injustiça social paira sob as mulheres que "encerradas entre paredes imundas de um prostíbulo, não têm (ou pensam não ter, o que vem a dar no mesmo), o direito de sair à rua, de mudar de bairro, de abrir a janela, de ver a luz do sol, de usar o próprio nome" (Ibidem, p. 3). E acrescenta:

Dissemos que a prostituição é uma forma de escravatura feminina, e o é realmente pela natureza das causas que levam a mulher a se prostituir, pelo gênero de vida que ela se vê obrigada a levar, pela exploração que, em torno dos seus lucros vultuosos ou reduzidos, se organiza, quer no plano local, quer no cenário internacional (...) Começando pelas causas da prostituição, queremos salientar que a mulher, salvo exceções que vêm confirmar a regra - só ingressa no meretrício levada pelo insuficiente amadurecimento psíquico 
(menoridade), por anormalidades físicas ou mentais, por excessiva pobreza, pela desorganização do meio familiar, por falta de educação intelectual, moral e profissional, sendo também inúmeros os casos em que a vítima de um atentado sexual e julgando-se 'desonrada' - é atirada ao meretrício por força dos preconceitos que Ihe impedem, mesmo na qualidade de vítima inocente, aspirar a uma vida normal.

Ferraz relata também os casos de abusos sexuais (pedofilia) em plena infância, geralmente cometidos por membros da família (pai, padrasto, cunhado, irmão), em sociedade que, por outro lado, age com um rigor quase medieval no tratamento dispensado à mulher ("perdida") que teve (perdeu) o seu status virginitatis, justificando desta forma o grande número de jovens meretrizes, de jovens com gravidez precoce, doenças sexualmente transmissíveis, abortos (Ibidem, p.6).

Ferraz menciona ainda a obrigatoriedade da inscrição da prostituta ou "registro das prostitutas", que as obriga a freqüentar o ambulatório médico-sanitário para inspeção de saúde, para que esteja apta para exercer sua profissão. Esta referência nos remete imediatamente a um dos textos que pretendemos mais tarde analisar, o célebre conto de Baltasar Lopes "A Caderneta", em que o autor apresenta com maestria a recusa da personagem principal, uma lavadeira pobre, em se registrar, e por conseqüência, ter em mãos uma caderneta-símbolo de sua discriminação, já que afirmava não ser "prostituta como as demais", em virtude das circunstâncias que a levaram à exploração do próprio corpo.

Para Ferraz, este sistema regulamentarista remete à escravatura feminina organizada, tolerada, autorizada e incentivada pelo Estado, "que se transforma embora não o saiba ou não queira - no máximo proxeneta" (Ibidem, p. 9). Inscrita obrigatoriamente no registro das prostitutas, deve a meretriz (assim marcada mais profunda e indelevelmente do que o seria pelo ferro em brasa) sujeitar-se a um regime aviltante, em parte imposto pelos regulamentos administrativos de natureza policial ou sanitária (Ibidem, p.10).

Num encontro entre as opiniões da pesquisadora e as posturas do governo cabo-verdiano por nós examinadas anteriormente, Ester Ferraz ressalta que o Estado não tem o direito de aceitar a prostituição, assim "higienizada, depurada do parasitismo criminoso que a costuma cercar. Mas que constitui objetivo das campanhas governamentais combater as causas que empurram essas mulheres a cometerem tais violências com seus corpos" (Ibidem, p.14). 
Em relação à prostituição, essa por si só não é crime em Cabo Verde; entretanto, atividades de exploração da prostituição são condutas tipificadas em vários crimes distintos, como o lenocínio_ que consiste no fomento, favorecimento ou facilitação do exercício da prostituição ou na prática de atos sexuais de menores de 14 anos ou de pessoas sofrendo de incapacidade psíquica _, compreendido como privação da liberdade feminina, previsto no artigo 148. do Código Penal, punido com pena de prisão de 2 a 8 anos (no caso de menor de 16 anos ou de pessoa em necessidade econômica extrema, a pena será de 1 a 5 anos). Desse modo, visa-se reprimir a exploração dessa atividade, sobretudo nos casos em que a vítima é utilizada como objeto e muitas vezes manipulada diante das dificuldades econômicas que enfrenta.

O tráfico de pessoas para exploração sexual, em especial crianças e/ou adolescentes, também, encontra-se previsto na legislação penal cabo-verdiana na figura de "aliciamento de menor para prática de ato sexual no estrangeiro", punido com pena de prisão, segundo o artigo 149. do Código Penal. A pena dos crimes a criança (12 anos), a adolescente ou a mulher pode ainda se agravar, caso venham a ocorrer gravidez decorrente da violação sofrida, transmissão de doenças (SIDA ou ainda contágios por DST) ou suicídio da vítima.

Em Cabo Verde, a população é predominantemente jovem, com média estimada em 21 anos, e as dificuldades extremas de sobrevivência nas zonas rurais muitas vezes provocam a migração para as cidades, concentrando as atividades da população pobre nos portos e no comércio.

A cidade do Mindelo, com seu Porto Grande, vem a ser um dos palcos privilegiados para a sobrevivência desta população, muito embora já não apresente a movimentação que o qualificava, entre 1850 e 1902, como rota obrigatória dos navios a vapor, pelas características que o diferenciavam, por exemplo, do porto da Praia (na ilha de Santiago) e de Sal Rei (na ilha da Boavista), das quais se destacam suas águas profundas e sem baixios, com fundeadouros seguros. No período referido, a ilha de $\mathrm{S}$. Vicente passa, de um espaço semi-habitado e periférico (à ilha de Santiago, centro econômico, social e administrativo do arquipélago) usado apenas para campo de cabras trazidas de outras ilhas e habitado por degredados, prostitutas e aventureiros, a importante pólo de crescimento demográfico, social e econômico. 
Esclarece o historiador António Leão Correia e Silva (2005, p. 51) que, como porto transatlântico (o mais importante do médio Atlântico), o Porto Grande de S. Vicente, pela sua posição estratégica vital entre três continentes, desencadeará uma febre de atividades econômicas que atrairão os camponeses pobres das ilhas agrárias ao redor (Santo Antão e São Nicolau), assim como os marinheiros trazidos pelo tráfego internacional, proporcionando o aparecimento da cidade do Mindelo (1879), com espaços sociais plurais. Ergue-se toda a estrutura urbana necessária a um porto que pudesse atender à tecnologia de transportes a longo curso da época _em que a navegação a vela foi substituída pela máquina a vapor _, às linhas de tráfego (que ligavam o Norte da Europa à América do Sul), ao novo tipo de emigração (os ingleses vão investir na abolição do tráfico negreiro e surgem as levas migratórias de camponeses pobres europeus). Estações carvoeiras são estabelecidas pelos ingleses no Mindelo, elegendo seu porto como o mais conveniente do ponto de vista da náutica a vapor.

Essa estrutura portuário-carvoeira do Porto Grande vai compor a população do Mindelo com imigrantes à busca de emprego, configurando a cidade como espaço masculino de (estivadores, catraeiros, mergulhadores, contrabandistas), nas suas duas primeiras décadas. Os marinheiros de passagem já encontram, no outrora antigo burgo, agora cidade-porto, botequins e bordéis. Desembarcados, são guiados pelos "meninos de ponta de praia", famosos personagens da literatura cabo-verdiana que se apresentam como cicerones, contrabandistas, ladrões ou gigolôs. Esclarece António Leão Correia e Silva (2005, p. 133):

\begin{abstract}
Aberto ao trânsito internacional, recebendo anualmente uma população flutuante mais de 15 vezes superior à da cidade, 0 Mindelo, como quase rodos os portos de condições semelhantes, é um ambiente onde a prostituição prospera. As doenças venéreas ganham, aqui uma extensão preocupante (...) na ilha de S. Vicente, onde a prostituição não está regulamentada.
\end{abstract}

A época é 1881-1882 e a afluência de meretrizes de todas as ilhas, associada à propagação da sífilis, leva a Delegacia de Saúde a matricular as prostitutas, a fim de poder fiscalizar sua saúde e internar as sifilíticas $\mathrm{O}$ conto de Baltasar Lopes, "A caderneta”, enfocará este tema, que será adiante examinado à luz do trabalho literário. 
Mas na boca do porto ou "ponta de praia", como a linguagem local designa, logo surgirão serviços tipificados, à época, como femininos: a prostituição e, com o decorrer do tempo, o transporte do carvão, atividade conquistada ao espaço masculino por algumas mulheres.

Todavia, a prostituição não é fenômeno exclusivo do Mindelo ou de Cabo Verde, ao contrário, o país está inserido entre muitos, já que a história da prostituição é antiga e sobrevive aos dias atuais, em especial, com jovens menores de idade.

Em relação ao fenômeno da prostituição de jovens, fatores que julgamos ser preponderantes em Cabo Verde são: o fato da maioria das famílias serem chefiadas por mulheres; o alto grau de desemprego; a falta de qualificação profissional feminina.

O antropólogo José Carlos Gomes dos Anjos (2005, p. 164), considerando que o contexto pós-colonial não é pior do que o sistema escravista e do que o patrimonialismo colonialista pós-escravidão (ambos de violentação sistemática das mulheres dos segmentos sociais dominados), enfatiza 0 atual processo de desagregação das estruturas familiares urbanas em Cabo Verde, em virtude da ausência de pai para impor limitações e assistência:

[...] até mesmo podemos dizer que só sua presença, já exigiria outro tipo de conduta comportamental. O pai sempre foi um modelo cultural a ser respeitado na sociedade, e esta ruptura, ou seja, a ausência dele dentro do seio familiar, de alguma forma apresenta alteração no comportamento das jovens.

Acrescenta o pesquisador que

[...] o patriarcado é, no atual processo de desagregação das estruturas familiares extensivas no meio urbano cabo-verdiano, não apenas um modelo cultural que tende a eximir os jovens do sexo masculino quanto à responsabilidade com relação à saúde sexual e reprodutiva, mas sobretudo tende a canalizar 0 foco das investigações para o comportamento feminino, isolando essa dimensão de suas relações estruturais com as atitudes masculinas (Ibidem).

Aponta ainda Anjos que o fenômeno da "pixingaria" é sintomático da prostituição juvenil em Cabo Verde, aliado ao "caranganhada", tipo mais conhecido como "cafetão" ou "menina que tem um namorado cafetão". Esse segmento 
comportamental da pixingaria substitui atualmente a figura da prostituta clássica (profissional) e pode ser associado ao desemprego, que leva ao aumento do número de jovens proveniente das regiões rurais que buscam na cidade e nas relações sexuais em troca de favores um meio de sobrevivência.

Define o antropólogo (ANJOS, 2005, p. 164):

Pixingaria é em Cabo Verde a expressão local para designar um tipo de comportamento sexual juvenil que não é necessariamente percebido como prostituição, embora se pressuponha que na maior parte das vezes envolva a troca de algo material por sexo. Desde o comportamento de meninas de classe média, que ficam com vários namorados em troca de jantares e freqüência a boates caras, até as mães precoces de classe popular que se prostituem para alimentar filhos, são chamadas de pixinguinhas as meninas que, estigmatizadas para o mercado matrimonial, se supõe estarem expostas a um mercado sexual extraconjugal e, portanto, imoral

As DSTs (doenças sexualmente transmissíveis), as drogas e o risco de exclusão social aliam-se às categorias de jovens mais estigmatizados do mercado matrimonial e sexual cabo-verdiano, dentre os quais se destacam os mandjacos (jovens estrangeiros de países vizinhos), as pixinguinhas (meninas entre 15 e 20 anos em início de carreira de prostituição) e os caranganhadas (namorados informais dessas meninas).

Vítimas de um sistema sócio-econômico e cultural, as pixinguinhas avançam a caminho da marginalização e até à prostituição efetiva o salto é rápido, acompanhado da necessidade material, do consumo de álcool e drogas.

Em uma cultura profundamente machista, a iniciativa feminina é o signo primeiro da distinção entre a pixinguinha e as mulheres "sérias". A manifestação de um interesse material, a forma como expõe o corpo para provocar o desejo masculino são outros índices daquele comportamento. A pixingaria inverte o quadro erótico tradicional, que retratava os homens como "mulherengos" e as mulheres como recatadas.

A violência sexual, sofrida muitas vezes dentro de casa, atinge seu ápice no contacto com o turismo, em que crianças são expostas ao circuito de uma sexualidade mercantilizada (ANJOS, P. 59), que pode manifestar-se em pixingaria ou em prostituição.

Outra variação atual da prostituta denomina-se "macaca", profissional que se veste bem; usa perfumes de marca, possui telemóvel (celular) de última geração, 
mora num apartamento bem mobiliado, é instruída, fala português corretamente e não procura os clientes, pois é procurada. É a nova geração de prostitutas que visa uma clientela mais exigente, composta por empresários, investidores, narcotraficantes. As mais jovens, de idade entre 13 e 25 anos, são chamadas de "macaquinhas". As mais experientes são as "Macacas Sênior", donas do seu negócio e de atuação discreta, distinguindo-se da "antiga prostituta do Lombo" e da "mamazan" ou "mama", que tinha "meninas de vida" a trabalharem para ela (Confirase "Macaca: a mais nova cara da prostituição"; online).

No que se refere à prostituição infantil, à pedofilia e à gravidez precoce, um estudo sobre trabalho infantil realizado em Cabo Verde, envolvendo 884 crianças, concluiu que 10,3 por cento dos inquiridos admitiu ter mantido relações sexuais com adultos, alguns a troco de dinheiro e identificaram os adultos como não sendo caboverdianos ("estrangeiros"). Do total, $25 \%$ das crianças pertencem à faixa etária dos 7 aos 13 anos e 34\%, à dos 14 aos 17 anos

O estudo foi elaborado no âmbito do Plano Nacional de Luta contra o Trabalho Infantil e indica também que há crianças "correios" (vendedoras) de droga em Cabo Verde. O trabalho foi encomendado por uma equipe de consultores que concluiu que o trabalho infantil em Cabo Verde "é uma realidade indesmentível" (Confira-se "Cabo Verde: pedofilia e crianças correios de droga". Página Um blogspot, 2007).

O antropólogo Orlando Borja, que participou na elaboração do estudo, confirmou à Rádio Nacional o envolvimento de crianças no tráfico de drogas, que considerou uma das piores formas de exploração infantil, ao lado da prostituição, também constatada em Cabo Verde, embora sem assumir a proporção endêmica de outros contextos. Como causas desta situação, o estudo aponta a pobreza, questões culturais e novas dinâmicas e possibilidades apelativas do mercado.

Seja como for, conclui-se que os direitos das crianças cabo-verdianas vêm sendo violados.

Segundo os resultados do inquérito, das crianças que trabalham 37,2 por cento fazem-no no interior do agregado familiar e 58,4 por cento fora. Entretanto, a participação dos que laboram fora do agregado tende a aumentar com a idade, verificando-se situação inversa no que concerne às atividades no interior do agregado familiar. Os setores do comércio e serviços são os que mais demandam a 
mão-de-obra infantil e há fortes probabilidades de que a trajetória profissional das mães condicione a trajetória das crianças.

O trabalho infantil em Cabo Verde constitui o prolongamento de atividades iniciadas no lar, para serem executadas por crianças na rua, sendo os pais, portanto, os maiores empregadores. A estatística diz que mais de 400 crianças em Cabo Verde são chefes de família, sustentando-a com seus rendimentos (Ibidem).

A precoce inserção das crianças na atividade econômica vem sendo vista como negativa já que são obrigadas a se transformar em provedores de rendimentos para si e para a família, o que acaba por lhes roubar a infância.

O grupo de trabalho optou por adotar um plano de ação para a eliminação do trabalho infantil por meio de uma estratégia coordenada em duas frentes: incrementando um forte trabalho que vise um amplo desenvolvimento, a erradicação da pobreza e a mobilização social, e, de outro, estabelecendo políticas prioritárias de estruturação jurídica e institucional sobre o tema.

Assim como se iniciam precocemente no trabalho, as crianças caboverdianas tendem a se iniciar precocemente na vida sexual.

Há algum tempo que a iniciação precoce da atividade sexual e a gravidez precoce são problemas que Cabo Verde tem vindo a enfrentar, com maior incidência nos centros urbanos, Praia e S. Vicente. Cerca de 10\% das adolescentes, entre 15 e 17 anos, abandonam a escola em virtude da gravidez precoce, revela a socióloga cabo-verdiana Antónia Teixeira (Confira-se "Gravidez leva 10\% das jovens de Cabo Verde a largar estudo", 2009).

Muito embora Cabo Verde já constitua um exemplo para outras nações, visto que a saúde sexual e reprodutiva está na agenda do dia e integrada no sistema de saúde, evidenciando muitos progressos, a problemática da gravidez precoce e do início precoce da atividade sexual persiste.

Um avanço, por exemplo, é a redução do número de filhos, que perfazia sete em 1979 e hoje se situa entre os 2,8/2,9, com redução significativa da mortalidade materna no parto e pós-parto. As mulheres preferem os centros de saúde a terem os seus filhos, em casa, bem como recorrem às consultas de planejamento familiar.

Mas a gravidez na adolescência e a violência contra as mulheres são problemas que persistem e exigem solução rápida e o Serviço de Saúde Reprodutiva tem buscado, em parceria com as Delegacias de Saúde locais, alternativas para criar unidades de atendimento específico para adolescentes, onde 
estas se informem sobre as formas de se prevenir das infecções sexualmente transmissíveis, da problemática da gravidez precoce, bem como sobre as conseqüências da entrada precoce na vida sexual.

Exposto esse quadro, que trata das barreiras e conquistas das mulheres cabo-verdianas no panorama social, procuraremos evidenciar como os textos literários transpõem para a arte ficcional os fatos retratados. 


\title{
CAPÍtULO 3
}

\section{LITERATURA E REPRESENTAÇÃO SOCIAL DAS MULHERES EM CABO VERDE}

\author{
Em Cabo Verde, quando nasce uma menina, ela já é uma mulher. \\ Dina Salústio
}

A história das mulheres cabo-verdianas constitui uma saga, cuja luta vem sendo traçada desde seu nascimento, nas batalhas travadas pela sobrevivência e em busca de um lugar reconhecido na sociedade. Em consonância com as palavras de Dina Salústio, em entrevista na cidade da Praia, 1994, à professora Simone Caputo Gomes (2008, p. 218), quando nasce uma menina, ela já é investida nos seus papéis sociais de mulher.

Embora sejam atribuídas às mulheres cabo-verdianas tarefas como chefiar a família, educar os filhos, administrar a economia familiar, inclusive os valores enviados do exterior pelo marido emigrado, sua emancipação ainda está em processo, e muitas formas de exclusão continuam a ser praticadas contra elas.

A ideologia patriarcal, aliada á opressão imposta pelo colonialismo, valeu-se de estratégias autoritárias para excluir as mulheres (e outros grupos) das escalas e atividades de prestígio na sociedade, inclusive no que toca à autoria literária. No bojo desse processo, a ordem androcêntrica perpetrou também outra forma de violência que reduzia a mulher ao espaço restrito do privado e do cotidiano, subjugando-a aos domínios masculinos oriundos do espaço público.

Por muitos séculos, a sociedade ocidental tem mostrado vários tipos de preconceito com relação às mulheres, subvalorizando suas capacidades, sua força de trabalho e obliterando a sua historicidade. A redução de suas funções sociais à maternidade exclusivamente (geradora) e à serviçal doméstica não-remunerada, e o confinamento ao espaço do lar e da família, rasurou por muito tempo as suas capacidades de desempenho de outras funções.

Segundo estatísticas dos últimos Censos, hoje, grande parte das mulheres (aproximadamente 62\%) são chefes-de-família num Cabo Verde de economia 
predominantemente agrícola, e o excessivo número de imigrantes do gênero masculino faz com que passem a desenvolver atividades que, de certa forma, as forçam a lançar-se na esfera pública, em busca de realização familiar, pessoal e financeira.

Corroborando afirmação de Simone Caputo Gomes (2008, p.274-275), que tem analisado há longo tempo a participação das mulheres cabo-verdianas na produção literária, em consonância com os papéis sociais exercidos por elas para o desenvolvimento de seu país, grande salto para a emancipação e a valorização femininas deu-se quando:

Na Primeira República (de 1975 a 1990), a Organização das Mulheres de Cabo Verde (OMCV), criada em 1981 com base nos princípios políticos do PAICV e composta por mulheres que participaram no processo de luta pela independência de Cabo Verde, contribuiu decisivamente com suas intervenções para o processo de igualdade se refletisse nas áreas da sobrevivência, saúde, educação, economia, informação e formação. Hoje constitui uma organização não-governamental, que insiste na sensibilização da sociedade crioula para que valorize papel da mulher no processo de desenvolvimento.

Atualmente, Cabo Verde conta com inúmeras associações criadas pela sociedade crioula para equacionar e apoiar na questão da equidade de gênero, no sentido de dar visibilidade à ação histórica das mulheres. Merecem destaque a MORABI (Associação de Apoio à Auto-Promoção da Mulher no Desenvolvimento), de 1991, a Associação das Mulheres Empresárias, criada no ano seguinte (1992), o Instituto da Condição Feminina (ICF), de 1994, cujos objetivos visavam integrar efetivamente a mulher em todos os segmentos da vida social, econômica, e política, conferindo a elas o pleno direito de participação no desenvolvimento de Cabo Verde.

Nos ano noventa, com a instituição do pluripartidarismo, este desenvolvimento se acentua, como sublinha Gomes (ibidem.p. 276):

Na Segunda República, após a abertura política e realização das eleições pluripartidárias (1991) vencidas pelo MPD (Movimento Para a Democracia), atribui-se à mulher maior protagonismo ao incrementar políticas especialmente dirigidas a ela no III Plano Nacional de Desenvolvimento: maior integração das mulheres no processo de modernização da agricultura; desenvolvimento do emprego feminino e das cooperativas de mulheres; acesso ao crédito e criação de projetos de desenvolvimento para mulheres. 
Não é demasiado ressaltar os sucessos que as mulheres cabo-verdianas vêm conquistando, ano após ano, as posicionam já em todas as profissões e cargos, desde a mais humilde até as mais politizadas, como podemos comprovar em um dos capítulos da Conferência dos Direitos Humanos de 2007, de Vera Duarte (DUARTE, 2007, p.118), escritora e desembargadora:

Foi assim que, paulatinamente, o princípio da igualdade foi encontrando consagração nas leis da família, do trabalho, da participação política, do foro criminal.

Desde que houvesse a vontade política, e havia-a, essa era sem dúvida, a tarefa mais fácil: mudar a legislação, adaptar todo o nosso ordenamento jurídico ao princípio da igualdade.

Hoje as mulheres cabo-verdianas estão em todas as profissões, contrariamente ao que se passava na era colonial em que várias profissões eram pura e simplesmente interditadas às mulheres.

Hoje temos mulheres deputadas, ministras, magistradas, diplomatas, funcionárias das finanças e das alfândegas, o que não acontecia antes da independência.

$E$ acho que não corro o risco de errar se disser que nas profissões ligadas as actividades da ASA, Empresa de Aviação e Segurança aeroportuária, é que as conquistas são mais sensacionais: Hoje temos mulheres controladoras de tráfico aéreo, temos mulheres bombeiros, e - pasmem-se - temos mulheres pilotos!

A promoção da mulher, de sua cidadania em igualdade de direitos, faz parte de uma meta que, embora em andamento, tem demonstrado sua eficiência, apresentando resultados positivos, como a emancipação das mulheres rurais e daquelas que vivem em periferias urbanas, e no combate à violência doméstica. $O$ incentivo à educação também faz parte das lutas travadas em prol de sua emancipação efetiva.

Não obstante, mesmo alcançando todas essas conquistas - sociais, econômicas e culturais - a sociedade cabo-verdiana ainda apresenta mazelas que impedem as mulheres de alçar vôos plenos.

A violência doméstica, cometida pelo companheiro, a persistência da prostituição, do turismo sexual, o tráfico de mulheres para o exterior, a maternidade precoce, o aborto clandestino, a pedofilia, o alcoolismo ainda estão presentes em lares cabo-verdianos, e os órgãos competentes têm buscado soluções através de parcerias e projetos, visando conscientizar cada vez mais a coletividade, beneficiando desta forma milhares de mulheres desprovidas de assistência. 
O enfoque governamental não prima apenas pela conscientização feminina, mas busca, sobretudo, assegurar ao cidadão cabo-verdiano direitos inalienáveis. Para tanto o Plano Nacional de Ação para os Direitos Humanos e a Cidadania PNADHC, tem desenvolvido ações, em parceria com o setor privado, para a promoção e proteção desses direitos, abrangendo todas as estâncias e segmentos possíveis: educação para os direitos humanos e cidadania; promoção da família; luta contra a pobreza; melhoria da saúde, justiça e segurança; benefícios aos portadores de deficiência, idosos, imigrantes, refugiados e repatriados, presos, e um desenvolvimento sustentável com inserção nos Sistemas Internacionais de Direitos Humanos, são as prioridades para sanar ou, no mínimo, amenizar a problemática social de Cabo Verde.

Em retomada à análise da situação social das mulheres cabo-verdianas, sua militância há muito vem se destacando, mobilizando todos setores da sociedade contra os preconceitos e buscando soluções no sentido de viabilizar alternativas para dirimir as desigualdades sociais.

Em nossa pesquisa, buscaremos examinar como os discursos literários de autoria masculina e feminina abordam, respectivamente, essa trajetória das mulheres cabo-verdianas na sociedade, com o intuito de comparar as formas de representação sob uma ótica de gênero, com suas especificidades. Apresentadas pela pena masculina ou assumindo-se, elas mesmas, na escrita, as mulheres caboverdianas constituem o foco de nosso estudo, seja como coadjuvantes do cenário, seja como protagonistas das cenas crioulas. 
Tchalê Figueira - Estudo de Anatomia, acrílico s/ tela, 150×200cm, 2004

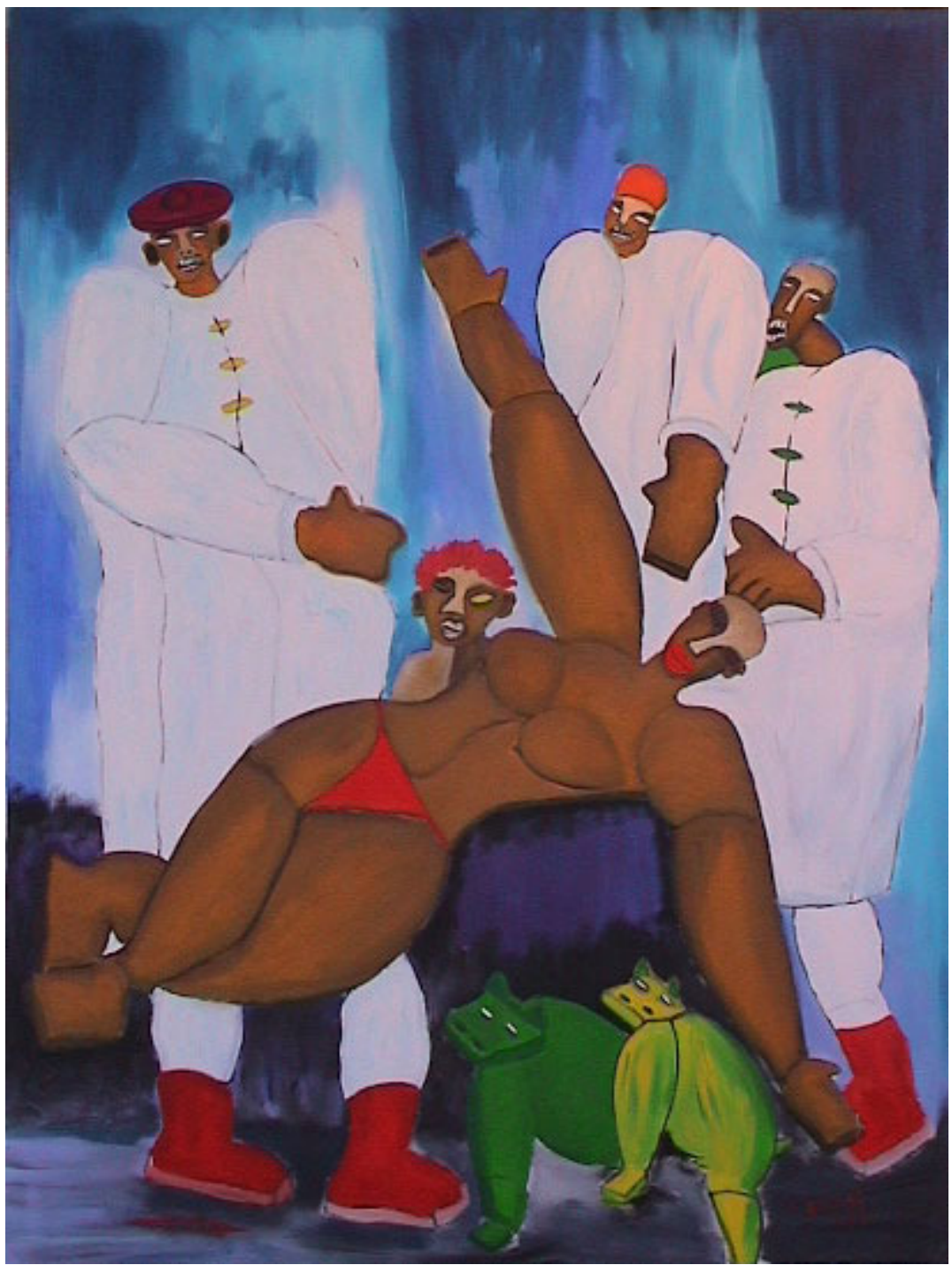




\title{
3.1. A PRODUÇÃO MASCULINA APRESENTA AS MULHERES CABO- VERDIANAS
}

\author{
Não é melhor um lar honesto e pobre? \\ Um carrasco brutal? Filhos? Canseiras? \\ O frio, a fome e a dor? \\ Não é mais nobre \\ Leite nos seios? Palidez? Olheiras? \\ Os vestidos de seda são tão caros, \\ Oh! Pobres vítimas vindas do nada!... [...] \\ Milagres tem às vezes feito o amor \\ Desatolando os anjos dos bordéis... \\ Mas isso é muito raro... Minha flor ...

\section{Eugénio Tavares}

Investigar como a escritura literária masculina representa a mulher caboverdiana na literatura nos remete a uma questão: como o imaginário masculino concebe essa mulher? Como a caracteriza no campo das letras?

Para Susana Bornéo Funck (2003, p. 476),

[...] a análise feminista da literatura produzida por homens torna-se, assim, desde seu início, uma crítica da cultura sexual patriarcal (...), uma vez que a mulher é idealizada e que a construção cultural do desejo masculino traz embutida a noção de conquista e dominação do objeto.

A sexualidade, nas sociedades patriarcais, é centrada no prazer masculino, o que gera representações do corpo feminino como "maleável, instrumental e descartável" (Ibidem, p. 476).

Acrescenta Maria Lúcia Rocha-Coutinho (1994, p. 26) que o discurso da "natureza feminina", o confinamento das mulheres à esfera doméstica e a maternidade como programa político dão suporte à ideologia falogocêntrica.

$\mathrm{Na}$ Grécia Antiga, o homem era a figura do chefe de família, que detinha a autoridade e o poder na "casa", onde mantinha suas obrigações para sedimentar sua reputação de cidadão. Apesar disso, o pensamento de que a mulher era indiscutivelmente submetida ao homem e não contestava este fato é absolutamente simplista. Se o homem exercia poder sobre a mulher, enquanto representante da 
casa perante a sociedade, e isso o colocava em lugar de destaque, por outro lado a mulher também exercia poder sobre ele, porque este dependia dela para gerar herdeiros.

Nas palavras de Foucault (1984, pp.150-151),

[...] a arte de se conduzir no casamento se definiria menos por uma técnica de governo e mais por uma estilística do vínculo individual [...]; o princípio de moderação da conduta num homem casado se situa nos deveres da reciprocidade mais do que no domínio sobre os outros; ou melhor, no fato de que a soberania de si sobre si manifesta-se cada vez mais na prática dos deveres com relação aos outros e, sobretudo, de um certo respeito com relação à esposa; a intensificação do outro; a nova maneira pela qual a questão da fidelidade sexual é às vezes formulada testemunha essa mudança [...] Uma estilística da existência a dois surge dos preceitos tradicionais da gestão matrimonial: podemos muito bem situá-la numa arte do vínculo conjugal, numa doutrina do monopólio sexual, e finalmente, numa estética dos prazeres compartilhados.

Todavia, Foucault sugere ainda outros indícios de que a mulher não aceitava simples e passivamente a sua condição de inferioridade e submissão, como, por exemplo, o ciúme sexual, que constitui uma forma de reprovar os maridos quando estes vão buscar prazer fora de casa. Trata-se de um discurso contra os poderes, antecipação de uma liberdade futura.

As obras literárias ocidentais de autoria masculina têm buscado representar, ao longo do tempo, dois tipos de mulheres: as circunscritas ao lar (mãe, esposa) e as que circulam na rua (prostitutas, na grande maioria).

A mãe é a representação mais frequente, imaculada, assexuada, símbolo de lutas e sacrifícios; uma moça escolhida para seguir o caminho do matrimônio deveria requisitos que se aproximassem da imagem materna imaculada e a virgindade era como um troféu do qual o homem seria merecedor.

No caso de Cabo Verde, uma moça que namorasse muito ou fosse freqüentadora dos bailes e festas nas redondezas, corria o risco de ficar difamada. Esclarece João Lopes Filho (1996, p. 151), sobre a ética em terras crioulas:

Os valores morais e sociais possuem características quase universais - uma vez que dizem respeito a um conjunto de determinados ideais e de princípios Assim, todos os homens têm, por exemplo, a noção de que o bem deve fazer-se e de que o mal deve evitar-se ... O sentido de honra/desonra (ou vergonha) segundo o qual se sacrificam a causas elevadas por ideais mais 
sublimes, presente na sociedade cabo-verdiana, é característico das formas de pensar e agir das sociedades ibéricas assim como das sociedades européias pré-industriais, e é um dos valores ou ideais sociais mais difundidos na sociabilidade das populações deste arquipélago.

Quanto ao segundo estereótipo feminino, as ingênuas e sonhadoras que, por imaturidade, se deixassem levar pelas promessas de amor eterno, convertiam-se em vítimas, acabando por não preencher aos requisitos exigidos por aquela sociedade machista, sendo excluídas das expectativas e pedidos de casamento.

A moça, marcada pela sociedade machista como "libertina", eram recusadas pelos rapazes que buscavam compromissos sérios, e, não raro, eram vítimas de difamação.

Segundo apontamentos de Luis Manuel de Sousa Peixeira (2003, p.111), em Cabo Verde:

O casamento significa, ao mesmo tempo, um sacramento e um rito de passagem que marca uma mudança irreversível na vida de cada indivíduo... Ao assumir-se como instituição, reveste-se de preconceitos, entre os quais, o da "posse" e o da virgindade.

Recorrendo à História da Arte Ocidental, os corpos femininos, desde as representações da pintura e da escultura, estavam destinados ao deleite masculino e os nus artísticos exibiam sua passividade, sua submissão ao olhar masculino.

A mulher, enquanto objeto (de cama, mesa, afazeres domésticos e exibição artística) para o consumo do homem, passaria, no século vinte, a reivindicar a liberdade, inclusive corporal.

Nas obras de autoria masculina selecionadas para nosso corpus, várias foram as passagens relevantes a esse assunto, como diálogos de mãe e filha num aconselhamento de boas condutas, proibições das idas precoces aos bailes populares da época, reprovações masculinas a certos comportamentos etc. Observa-se a preocupação dos escritores em resguardar a dignidade e a honra feminina e, por conseguinte, a honra da família.

O patriarcalismo cabo-verdiano, enquanto um conjunto de normas advindas do colonialismo e elaboradas por homens, europeus, brancos, católicos, vem calcado em práticas autoritárias que excluíam certos grupos sociais do seu centro de 
interesse. Os negros, os homossexuais e as mulheres ameaçavam a ordem das leis, tendo, portanto, seus valores minimizados pela sociedade.

A literatura cabo-verdiana, na sociedade colonialista e machista da década de trinta do século vinte apresenta as mulheres, prioritariamente, sob dois prismas: aquelas que lutavam pela sobrevivência perante a seca com dignidade e resignação, e as que partiam em busca de sobrevivência pelo viés da emigração, ou da prostituição (especialmente pela emigração par Dacar, Senegal), acreditando serem esses os únicos caminhos plausíveis reservados a elas.

Jorge Barbosa, um dos fundadores da revista Claridade (1936), apresentanos num poema as "Jovens meretrizes/ da cidade portuária/ da ilha de S. Vicente", quase como um destino da jovem crioula que não consegue manter-se nos esperados padrões casadoiros de conduta.

Em um dos poemas de Eugénio Tavares, epígrafe desta secção de nosso estudo, a "Perdida" é a representação da mulher que "cai" na prostituição e é vítima do abandono familiar, visto que, na maioria dos casos, os patriarcas não aceitavam tais deslizes, ocasionando sua expulsão do lar, sem alternativas para suprir suas necessidades básicas. Outras vezes, estas moças eram seduzidas pelos namorados, que acabavam por abandoná-las e, em decorrência, elas se lançavam à vida marginal para fugir à miséria (TAVARES, 1996, p. 49).

O tom de aconselhamento quase patriarcal contido nos poemas de Jorge Barbosa e de Eugénio Tavares, suas preocupações com o destino determinista das jovens cabo-verdianas que se afastam do reduto do lar, da sua missão de maternidade e das regras morais da família, deixa entrever os preconceitos masculinos embutidos na representação das mulheres prostitutas e das causas da prostituição, sobretudo as que residem em "falhas" ou "quedas morais" femininas.

Na ótica masculina, as mulheres discriminadas socialmente - as alcoólatras, as mulheres do funco, as prostitutas, as viciadas ou as perturbadas mentalmente sempre são submetidas a um jugo moral e exibidas como exemplos didáticos para exaltar ensinamentos relativos a condutas que ferem os padrões morais da sociedade ou para prescrever papéis sociais femininos ideais. Não há a preocupação de explorar a subjetividade feminina, os desejos secretos das mulheres, seus sonhos. Por mais engajados que alguns escritores estivessem em denunciar a condição social das mulheres cabo-verdianas, suas carências materiais, 
tais representações vitimizam as mulheres $e$ as posturas dos escritores assemelham-se às de advogados de defesa das imorais, das perdidas ou de protetores das virgens e inocentes passíveis de perdição (Eugénio Tavares) e loucura (“Virgens loucas”, de António Aurélio Gonçalves).

Ainda nas palavras de João Lopes Filho (1996, p. 152):

Honra e vergonha são preocupações constantes de indivíduos em sociedades pequenas e fechadas onde relações pessoais face-aface, por oposição a relações anônimas, são de extrema importância e em que a personalidade social do actor é tão significante como o papel que tem a desempenhar. Dentro dos grupos de solidariedade mínimos destas sociedades, sejam eles famílias ou clãs, as esferas de atuação são bem definidas, não se sobrepõem umas com as outras... O que é significante neste contexto mais amplo é a insegurança e a instabilidade da classificação de cada um no aspecto honra-vergonha. Mesmo quando a honra é herdada com nome de família tem que ser afirmada e posta à prova.

A literatura masculina de cunho social não oferece solução para o problema (apenas recomenda que as mulheres se conduzam estritamente segundo os parâmetros impostos), visto que o sistema colonial e seus modelos marcaram durante séculos os ditames comportamentais dos países de língua portuguesa. Entende-se, pois, a submissão das mulheres perante seus opressores jurídicos, sociais e políticos, ao aceitar tais regras que lhes negam direito à liberdade, desvalorizando ou deixando invisíveis os exercícios de papéis sociais produtivos em seu cotidiano.

\subsubsection{BALTASAR LOPES}

Os escritores, comprometidos com o bem-estar social, apresentam ao leitor denúncias reflexivas que focam problemáticas que incomodam e/ou não se coadunam com os padrões da sociedade. Uma delas, a prostituição em Cabo Verde, centra-se, sobretudo, na abordagem dos atalhos que levam jovens a trilhar este sofrido caminho, levando-se em conta toda a gama de preconceitos sofridos por elas, arraigados numa óptica machista. A análise expande-se, inclusive, à saúde, de homens e mulheres vítimas de doenças sexualmente transmissíveis. 
Baltasar Lopes, um dos fundadores da Revista Claridade, nascido na Ribeira Brava, zona rural do Caleijão, na ilha de São Nicolau em 23 de Abril de 1907 falecendo em 1989, é um dos primeiros autores a examinar a temática aludida, centrando-a numa protagonista feminina. Publicou, além do romance Chiquinho, em 1947, e do ensaio O dialecto crioulo de Cabo Verde (1957), o livro Os Trabalhos e os Dias (Linda-a-Velha, ALAC, 1987), no qual está inserido o conto "A Caderneta", fundamental para uma leitura da problemática social das mulheres cabo-verdianas sob a ótica masculina.

A obra Os Trabalhos e os Dias reúne dez contos publicados em diversas revistas, e o conto "A caderneta", publicado inicialmente (e ironicamente) na revista Vértice, em Portugal, porque não passou ao crivo da censura em Cabo Verde (certamente não deveria, naquela momento, ser lido por cabo-verdianos!) será publicado também em língua francesa, por ocasião das comemorações nacionais do cinqüentenário da Revista Claridade (1936 - 1986).

Para Arnaldo França (Apud Manuel Veiga, 1998, p. 122), "a prostituição é, no conto "A Caderneta", mais do que a denúncia de um flagelo social, um libelo contra a arbitrariedade do poder". No conto, observa-se a exposição argumentativa por parte da personagem feminina, uma lavadeira, vizinha de uma casa de "xungaria" (prostituição), que se apresenta anonimamente, como representante de tantas outras mulheres de semelhante situação econômica nas ilhas. Baltasar Lopes, com sua maestria literária, posiciona-se quase como um advogado em defesa daquele tipo de opressão que atingia muitas das mulheres menos favorecidas economicamente em Cabo Verde.

Denunciante dos problemas decorrentes do fechamento do Porto Grande, que outrora trouxera o progresso ao arquipélago (entre 1850 e 1902, como rota obrigatória dos navios a vapor), possibilitando trabalhos, sobretudo, para o homem, que sustentava a família, o conto retrata as mulheres que, no auge da atividade do porto da ilha de São Vicente, conseguiam outrora trabalhos nas lavagens das roupas dos estrangeiros viajantes e, no tempo da narrativa, só conseguem agora serviços de prostituição eventual como forma de sobrevivência:

Não nego, senhor doutor, não posso negar. Naquele dia recebi um homem. Era um estrangeiro, creio que era sueco, ou noruega, dum 
vapor que tinha chegado ao porto [...] O senhor sabe, o meu trabalho é lavar e engomar, mas quando a tropa estava cá em S. Vicente eu tinha sempre que fazer. Não me faltava trabalho de roupa. Agora nem dinheiro para a cachupa se aparece direitamente. Há dias a fio que passo a perentém. Mesmo quando pego dinheiro para comprar um litro de milho, donde recurso para a lenha, o carvão e a gordura? (2001, p. 104-106).

Tal comportamento gerava a necessidade, segundo imposição do governo colonial, de exame constante pelo médico sanitarista, como prevenção às doenças transmissíveis, mediante a apresentação de uma caderneta de controle sanitário, símbolo de discriminação e vergonha, na ótica da personagem. A posse deste cartão (ou "caderneta da vergonha") estigmatizaria a mulher, para sempre, como prostituta assumida, fato que personagem insiste em marcar como eventual e necessário, em virtude da impossibilidade de compra do alimento para sua sobrevivência imediata: "Onde posso eu fazer concorrência às raparigas novas que elas dão aos estrangeiros dos vapores? Onde, senhor doutor? Aquela gente não via que foi a minha necessidade que me fez receber o noruega? (Ibidem, p. 106).

Não por acaso, no conto "A Caderneta", de Baltasar Lopes, dá-se o diálogo entre a personagem lavadeira e um médico sanitarista, muito embora se destaque apenas a voz da mulher, como recurso narrativo para denunciar, pela voz feminina, a discriminação da sociedade à prostituta.

Renan Springer de Freitas (1985, p.18), explica o comportamento da protagonista, da seguinte forma:

[...] o ator admite os atributos pejorativos que são a ele imputados, mas nega a responsabilidade por seus atos. Assim, a mulher que se prostitui pode admitir o fato de estar exercendo uma atividade imoral, mas nega sua responsabilidade por tal ato alegando, por exemplo, uma inexistência de fontes alternativas de auto-sustento.

O olhar masculino de expectador, a visão de fora, domina o discurso de Baltasar Lopes, mas o conto é bastante inovador face às demais narrativas masculinas que examinaremos, porque dá ênfase à voz e à perspectiva feminina (mesmo que mediadas por um construto patriarcal), embora apenas apresente a situação discriminatória: "Que vergonha, senhor doutor! Que vergonha [...] O senhor 
doutor diga por favor ao Senhor Administrador que eu sou mulher da minha casa" (LOPES, 2001, p. 107). A formação de Baltasar Lopes em Direito e o seu humanismo talvez constituam motivos para essa acuidade quanto aos preconceitos e injustiças sociais sofridos pelas mulheres cabo-verdianas.

Ainda em relação a Baltasar Lopes, no romance intitulado Chiquinho (1987, p.84, capítulo 9) extraímos uma passagem na qual a personagem central, durante o período de emigração à ilha de São Vicente, conhece o amor carnal no Largo da Salina. Há descrições da figura feminina e de sua relação com a prostituição: Chiquinho conhece Armanda, uma cortesã que explora jovens que vendem seus corpos em troca de alimento e hospedagens.

Nhola arranjou-nos conhecimento com Armanda. Armanda reina sobre o seu grupo de mocratas ${ }^{1}$. Recebe o dinheiro e garante-lhes casa e comida. As mocratas vivem felizes naquele albergue em que recolheram a sua infância cheia de fome. Atendem aos fregueses de Armanda e em troca comem duas refeições a dia e tem um colchão de coco-de-milho para se deitarem.

Muitas das jovens, em Cabo Verde, sobretudo na época colonial, vendiam sua virgindade por alguns trocados, e nesse capítulo é mencionada a pequena Lucinda, que vende sua inocência a um comerciante por cem escudos; é mencionada também a dacariana ${ }^{2}$, esta por sua vez mais experiente no trato profissional. Armanda, a cafetina, recebe auxilio das autoridades para recrutamento de jovens meninas que constantemente chegam à sua porta. A denúncia da corrupção (assim como a ocorrência de pedofilia) é evidente neste capítulo (Ibidem, pp.84-85):

Os policiais, também, estão abusados. Querem tudo de graça, senão no dia seguinte põe uma pessoa com a caderneta na mão, o que é uma desgraça. Acarreta logo as inspeções aos sábados, no hospital. E todos fogem de menina de caderneta.

Segundo António Carreira, a emigração para o exterior, sobretudo para o Senegal, ou o deslocamento para outras ilhas de Cabo Verde operava-se de duas

\footnotetext{
${ }^{1}$ Mocrata - prostituta ainda muito jovem, adolescente (N. A).

${ }^{2}$ A dacariana era a caboverdiana que emigrava para Dakar, no Senegal, em geral para prostituir-se.
} 
formas: a primeira, a emigração espontânea e a segunda, a forçada. Neste caso, em especial, dava-se pelo motivo mais cruel: a busca pela sobrevivência. Nas palavras de Carreira (1984, p. 166), "Dacar, pela proximidade do arquipélago e por outras influências, a partir dos começos deste século, foi o pólo de atracção de caboverdianos, tal como a Guiné".

\subsubsection{VIRGÍLIO PIRES}

Ainda no âmbito da revista Claridade, Virgílio Pires, santiaguense da cidade da Praia (25 de Abril de 1935, morre em Março de 1985, em Lisboa), apresenta-nos "Lulucha" e "Titina", contos publicados no número nove da revista (1960).

Virgílio Pires, nessas narrativas, toma como protagonistas mulheres caboverdianas, seus sonhos e expectativas face a uma terra inóspita, quase improdutiva, denunciam inclusive a emigração feminina mal sucedida, desembocando na prostituição. No plano da diegese, o leitor pode observar o cotidiano das personagens Lulucha e Titina, vitimas da pobreza e da falta de perspectivas sociais, acabando por serem obrigadas à prostituição como meio de sobrevivência.

A princípio, o conto "Lulucha" apresenta-se com uma singela estrutura quase de conto infantil, descrevendo, na perspectiva das crianças que ela cuidava, as características psicológicas da jovem, seu aspecto físico, sua ternura e, a seguir, a migração do campo (interior da ilha de Santiago) para a cidade (Praia) e a sua gradativa derrocada, dado que, como adiante perceberemos, se faz freqüente na escrita literária cabo-verdiana masculina: "Lulucha era contente. Estava sempre a sorrir. Tinha a boca grande, e quando ria os dentes muito brancos apareciam. Era boa para os meninos. É certo que às vezes aplicava ao Chico algumas sonoras palmadas..." (PIRES, 2001, p. 498).

A estória da galinha Pelada, índice do enredo implícito (a degradação moral de Lulucha), aguça a reflexão do leitor. Observemos as pistas deixadas pelo narrador (Ibidem):

Quando Lulucha partiu, Pelada já tinha voltado com a ninhada... Daquela vez, quando Pelada voltou, vinda do monte de bredos que ficava atrás de casa, Pedrinho gritou: "São treze, Lulucha é quem 
acertou". Lulucha tinha partido. O pequeno calou-se e ficou a pensar na caminhoneta verde que se sumiu lá longe, na recta da Bolanha, e levou Lulucha para a Praia.

A migração interna do campo para a cidade, tão freqüente na vivência caboverdiana, diz respeito não somente aos homens, mas muitas mulheres jovens se aventuraram por esta trilha, e Lulucha é a representação ficcional de moças que, como ela, sonhavam ter melhores oportunidades de trabalho. Todavia, há um entrave nestas partidas: muitas delas só levavam consigo os sonhos na bagagem; sem estudos, sem qualificação profissional, que futuro promissor poderiam esperar? Que setores empregatícios haveriam de contratá-las? Seriam empregadas domésticas em casas de famílias mais afortunadas?

Todavia, as meninas rurais, que criavam galinhas e faziam destas uma extensão familiar (nomeando-as), não possuíam sequer noções de como compor uma mesa, que comportamento ter às refeições etc.

Lulucha sonhava em conhecer as magias da capital cabo-verdiana (Praia), sinônimo de poesia, a praça com música de corneta (p. 499), diferente do funaná ${ }^{3}$ do interior, de gaitas e ferrinhos:

As lojas eram deslumbrantes. Tinham toda a espécie de brinquedos. Carrinhos de corda, gaita, bolas, tambores, bicicletas, triciclos, balões (...) Lulucha dizia que, quando fosse à Praia, havia de trazer aos meninos muitas coisas (Ibidem, 499).

Um conto aparentemente pueril adverte para os problemas decorrentes de mudanças de espaço social para as quais a personagem não estava cultural nem profissionalmente preparada, na disputa de um mercado de trabalho escasso, principalmente após o fechamento das atividades do Porto Grande do Mindelo (ilha de S. Vicente). Muitos dos investimentos foram aniquilados e os trabalhadores, vítimas daquela situação econômica, viam-se desempregados ou com subempregos para sustento das suas famílias.

Outra personagem feminina indicia o destino de Lulucha no conto: Nhá Simoa, representante da sabedoria popular dos anciãos e da oralidade crioula, que

\footnotetext{
${ }^{3}$ Modalidade musical do interior da ilha de Santiago.
} 
dá conselhos para que a jovem não se afaste de seu povoado. Para Lulucha e os meninos, Nhá Simoa, velha e feia, simboliza o mau-agouro e a bruxaria:

Diziam que era bruxa. Os meninos faziam figas e metiam a mão na algibeira para ela não ver. Acocorava-se a um canto do quintal. E se Lulucha cantava aquela cantiga 'Nhô S. Pedro cá nhô mata'm Caela / Parmô Cala é badjadêra fox', ela dizia "Menina, abranda o brio do corpo... Rapariga nova pensa que o mundo lhe pertence ... Lulucha então respondia: 'figas, Nhá Simoa. A mim feiticeira não come. Tenho sangue amargo, fique sabendo' (Ibidem, p.497).

Lulucha, ao emigrar para a cidade da Praia, sem "abrandar o brio do corpo" e escapando de um casamento com o John, rapaz trabalhador da Assomada (interior rural da ilha de Santiago), acaba por cumprir a profecia de Nhá Simoa encantada pelo brilho ilusório da capital, passa por uma metamorfose que aponta para a trajetória de muitas outras jovens do arquipélago:

Muitos anos se passaram, e os meninos cresceram. Já não perguntavam:

- Mambia, Lulucha não volta?

Um dia, Pedrinho encontrou Lulucha na Praia. Aquele belo sorriso tinha desaparecido.

Lulucha tinha agora um ar triste. Pedrinho não pôde ver nela a Lulucha dos seus tempos de menino. Ela parecia-se, no vestido curto e apertado, no jeito, no falar com Minguinha, com Maria Zizinda. Elas moravam na Ponta Belém. E Pedrinho perguntou receoso:

- Onde moras, Lulucha?

- Moro... na Ponta Belém.

- Conheces Minguinha ... Maria Zizinda?...

Lulucha não respondeu. Depois baixou os olhos e contou a Pedrinho a sua história, desde que os tinha deixado. Uma história vulgar e muito triste. Semelhante, talvez, à história de Minguinha, semelhante à história de Maria Zizinda (Ibidem, p. 499-500).

A intermediação da passagem da alegre moça rural à triste prostituta da cidade se dá pelas mãos do Manito Mendes, "célebre pelas proezas", "rápido o manejo da navalha", com várias cadeias no currículo:

Lulucha deixou John e foi para a Praia com uma pessoa que não conhecia [...] não ouviu os conselhos de nhã Simoa, nem os de Mambia. Nem reparou nas lágrimas de Pedrinho. 
Quando subia para a carroceria da caminhoneta, ria-se alegremente, e os dentes brancos apareciam (Ibidem, p. 500).

O mesmo eixo temático repete-se no conto "Titina", que apresenta em flash back passagens da vida da personagem masculina. Neste conto, porém, a estrutura é inversa: o homem é escravo da paixão nutrida pela personagem Titina. Dona de seu destino, por opção e rejeição à pobreza à qual se submetia vivendo ao lado do anônimo companheiro, Titina opta por sonhar com mudanças espaciais (Dakar, Guiné, S. Tomé) que porventura venham a the proporcionar melhores condições financeiras. Observe-se que Dakar é, com freqüência, um destino de prostituição para moças cabo-verdianas e S. Tomé é o lugar do contrato ou ilha da sujeição.

Neste conto, em especial, Virgílio Pires tematiza o amor obsessivo de um homem por Titina e o desfecho de sua estória: sem ela, o amante mergulha no inferno do grogue, da sujeira e da fome:

Descia lentamente a escada de cimento. Os sapatos furados faziam um som oco ao baterem nos degraus. Lá em cima, na feira, havia alegria e vida, mas para ele tudo estava terminado, com o último cálice de aguardente. Agora era uma noite sem sono, entre lençóis sujos, que o esperava. E a fome do dia seguinte (PIRES, 2001, p.504).

Entre as várias denúncias expostas nesse conto, Pires relata as secas caboverdianas de quarenta, constantes, históricas, em que o arquipélago, sem recursos financeiros vindos de Portugal ou de qualquer outra instância estrangeira, fica marcado pela fome e pela miséria pela ausência de agricultura de subsistência. Grandes foram os esforços e planos emergenciais colocados em prática, na ânsia de amenizar as calamidades que assolavam o povo.

Consta que, em 1947-1948, o governo mobiliza-se na construção de Postos de Serviços de Assistência para socorrer o povo faminto, por não haver de onde tirar o seu sustento. Segundo o relato de António Carreira (1984, p.116):

Em resultado da concentração de elevado número de famintos junto ao paredão de resguardo, do lado que dá para a Praia Negra, onde se construíra um alpendre provisório para acolhimento dos indivíduos que iam receber a ração diária fornecida pelos Serviços 
de Assistência, o muro de suporte , talvez devido à má construção, e pela acção da forte lestada que se fizera sentir, desabou arrastando na queda centenas de pessoas. Isso aconteceu a 20 de Fevereiro de 1949.

Várias vidas se perderam naquele acidente do Posto de Assistência, já que os famintos se encontravam no horário de almoço quando o paredão desabou, sem dar-Ihes a oportunidade da fuga. Este acontecimento é relatado pela personagem masculina, num flash de memória:

\footnotetext{
E recordou-se do grande desastre. O paredão do quintal da Assistência tinha caído, esmagando os que ali estavam recolhidos. Era a hora do rancho e os famintos fizeram a sua última refeição. $O$ sangue correra, encharcando aquele chão amaldiçoado e as árvores cresceram cerradas, ensombrando o lugar (PIRES, 2001, p.504).
}

Virgílio Pires recorre, por meio da memória da personagem, a fatos históricos para colocar em evidência sua indignação social, retratando tragédias que atingiram seu povo como a decadência masculina pela bebida, a transformação da mulher de família em prostituta, os filhos não planejados, a emigração mal-sucedida, enfim, problemas que assolavam os cabo-verdianos em virtude do abandono político, econômico, social e educacional.

A transformação negativa de Titina é constatada ao final do conto, tal como se dera no texto "Lulucha". Aos olhos do personagem masculino Titina, detentora de uma sensualidade patente _ "A mulata de peitos opulentos de que tanto gostava e tanto o fizera sofrer" (p. 505) _ doravante afigura-se decadente, metamorfose atribuída aos seus devaneios, à busca constante do luxo e da fartura material, à recusa em construir uma família simples, com um marido dedicado, bom marceneiro, não obstante o vício pelo grogue.

Mulher pouco dada ao trabalho, Titina prefere viver na emigração, às custas de quem a sustente. É descrita como uma mulher interesseira, que usa seu corpo e sua sensualidade para manutenção de sua ganância, sempre em busca de mudanças, com espírito inquieto e aventureiro. A descrição destaca o perfil leviano da mulher, aproximando-a de uma meretriz, cujos valores são determinados pelos bens materiais a possuir. 
Personalidade forte, em contraponto à fraqueza do companheiro ("Titina é que o tornava mole. Mole e desavergonhado como um cachorro", p. 505), Titina acaba, como ele, por trilhar decepções e perdas:

Agora era uma preta como qualquer outra, carregada de filhos, peitos caídos, roupas desleixadas. Não tinha nada da rapariguinha dos bailes da Achada e dos passa-noites do Paiol [...]. O seu corpo, a sua maneira de falar, o seu sorriso, um olhar, os pormenores mais significantes sugeriam-lhe uma comparação. Ela não era a mesma. Mas isto fora há muito tempo. Tudo tinha passado. Tudo mudara para pior. Depois do regresso de S. Tomé, Titina procurara a sua vida. Conheceu outros homens, muitos outros. E a pouco e pouco se foram afastando (Ibidem, pp. 505-506).

A personagem masculina, por sua vez, passa a viver num mundo onírico ${ }^{4}$, tentando reconstruir as lembranças que Ihe restam da vida que tivera ao lado de Titina. Nas palavras de Gaston Bachelard (1990, p. 75):

O mundo real apaga-se de um só vez, quando se vai viver na casa da lembrança. De que valem as casas da rua quando se evoca a casa natal, a casa de intimidade? Essa casa está perdida, não a habitamos mais, temos certeza, infelizmente, de que nunca mais a habitaremos. Então ela é mais do que uma lembrança. É uma casa de sonhos.

Neste conto, tanto a personagem masculina quanto a feminina passam por transformações que espelham, de certa forma, as convulsões sociais e econômicas por que passa Cabo Verde no tempo da narrativa. O marceneiro, "amante enganado" termina seus dias na cadeia, bêbado, como ladrão de (provavelmente) "brincos, broches, trancelins" (PIRES, 2001, p. 505) para Titina, que "tudo queria", ao contrário do "nada" que pudera lhe dar.

Esta, continua sua trajetória: na primeira visita ao companheiro na prisão, "riu-se, brincou com todos os presos, disse coisas disparatadas e todos acharam graça. Como sempre, ela se dividia em vários pedacinhos e em cada olhar, em cada

\footnotetext{
${ }^{4} \mathrm{O}$ onirismo se dá através de alucinações visuais sob forma de sonhos vividos, muitas vezes com tanta intensidade que podem surgir no curso de estados confusionais, inclusive por intoxicação alcoólica. BACHELARD, 1990, p. 76.
} 
sorriso, ela de distribuía, se oferecia [...[. Conheceu outros homens, muitos outros" (Ibidem, p. 505-506).

\subsubsection{MANUEL FERREIRA}

Manuel Ferreira, escritor português (nascido em 1917, em Gândara dos Olivais, Leiria, e falecido em 1994, em Lisboa) casado com a escritora caboverdiana Orlanda Amarílis, foi autor de diversas obras que têm por tema Cabo Verde. A profunda consciência das problemáticas econômicas e sociais, a infertilidade da terra devido à falta de chuvas numa nação de agricultores, as tradições culturais crioulas marcam textos ímpares também pela denúncia à repressão colonial.

Os contos de sua autoria selecionados para nossa leitura, "Bèlinha foi ao baile pela primeira vez" e "Uma flor entre os cardos", extraídos da obra Terra Trazida, deixam entrever como o olhar masculino recorta o universo feminino.

Em "Bèlinha foi ao baile pela primeira vez", a protagonista é vítima de abuso sexual por parte de um companheiro de dança no baile de Zé de Canda, em São Vicente. Nota-se aqui, mais uma vez, a mulher representada como objeto de desejo do homem.

No conto, percebe-se a estrutura familiar considerada por muitos autores como característica do arquipélago, ou estrutura matrifocal, em que a mãe tem um valor central e o núcleo mãe-filho(a) é primordial, embora a ideologia patriarcal continue imperando nas relações sociais. A matrifocalidade, referida por António Carreira (1977), ganhou dimensão devido à ausência do elemento masculino (emigrado) por longos períodos, mesmo que contribuindo com apoio econômico constante e efetivo.

A estrutura familiar em Cabo Verde difere do modelo europeu de família nuclear, tornando-se conhecida como matrifocalidade, caracterizada por uma família alargada (MEINTEL, 1984, p.93-120). Geralmente as mulheres, concebidas como membros adultos estáveis, são responsáveis pela sobrevivência econômica do agregado; inclusive chegam a definir, pela posição que ocupam, a redistribuição de rendimentos. Quanto aos homens, têm-se configurado, historicamente, como 
ausentes e de escassa participação no agregado, dado o seu constante e estrutural movimento migratório resultando na criação de novos agregados matrifocais. Embora esses agregados sejam chefiados pelos homens, o apoio por eles recebido, seja do ponto de vista econômico ou de tomada de decisões, advém das mulheres.

Para Deidre Meintel (Ibidem, p. 112) o ethos patriarcal sustenta o princípio da autoridade masculina, não obstante as mulheres tomarem as decisões no cotidiano, com base no afastamento dos homens e na relação de proximidade entre mãe, filhas, filhas e filhos das filhas. Portanto, a matrifocalidade é uma manifestação da realidade concreta que emerge da impossibilidade de ter o elemento masculino a gerir os destinos da família, embora o seu lugar social seja resguardado, mesmo na ausência física daquele. Carlos Ferreira Couto (2001, p. 108) sobre os direitos da mulher em frequentar determinados eventos sociais em Cabo Verde, esclarece:

A valorização dada ao homem é patente na importância social do
casamento através do qual o valor prático da mulher se afirma. Se a
ausência do homem não é pertinente para a definição do papel da
mulher em relação ao interior da sua unidade residencial, em
relação ao exterior, ela é determinante. Com efeito, a mulher do
emigrante, tal como a viúva, não participa em nenhuma festa de
baptizado ou casamento. A participação nos grandes momentos da
vida social representados por essas festas são incompatíveis com o
afastamento do marido.

Concluímos que a presença masculina no lar, quer seja pela via do matrimônio legal, quer pela "união de facto", na sociedade cabo-verdiana, propicia um status regido por um código de honra.

No conto de Manuel Ferreira, o cuidado da progenitora em proteger a filha da sensualidade dos bailes de S. Vicente e de pessoas que não faziam parte do círculo social ao qual pertenciam, redunda em evitar maiores constrangimentos ou discriminações que porventura a família venha a sofrer.

De acordo com Luís Manuel de Sousa Peixeira (2003, p. 148-153), a vida social de São Vicente, nas duas primeiras décadas do século XX, estava dividida em três classes distintas: a primeira, os mestiços ou brancos descendentes dos antigos senhores, abastados comerciantes, alguns médicos, advogados, altos funcionários e portugueses residentes; o Grêmio recebia os membros da primeira classe. A segunda, era composta por pequenos comerciantes e artífices, por empregados de 
firmas de prestígio, por pequenos funcionários e convivia o espaço do Rádio-Club; e a terceira classe ou "pé descalço", englobava o grosso da população e seu espaço de convivência eram as sociedades recreativas populares. Esta classe vivia em bairros periféricos e as mulheres, muitas vezes abandonadas pelos pais dos seus filhos ou deles separadas em virtude da emigração, arcavam com a totalidade das responsabilidades da família.

Segundo Peixeira (Ibidem, p. 151), o baile nacional, que acontecia

[...] aos sábados à noite em várias associações recreativas e salas improvisadas, é uma verdadeira instituição; frequentado por todas as classes, constitui a expressão de alegria de um convívio numa terra de poucas diversões. Mas existiam áreas na cidade em que a mistura acontecia em que os diferentes grupos se consubstanciavam em "Espaço de Mistura".

A cena apresentada centra-se na sedução da personagem principal, uma jovem de catorze anos da periferia, ingênua, ansiosa por freqüentar os famosos bailes do arquipélago. A denúncia sutil de pedofilia em Cabo Verde é colocada em evidência Embora, como no Brasil, o abuso da inocência de uma moça menor de idade seja caracterizado como crime, a lei acaba por não ser cumprida de fato, pelo medo das conseqüências para a vítima e sua respectiva família. Como explica Ferraz (1952, p.6):

No Brasil, entretanto, os crimes contra a liberdade sexual tendo como vítimas adolescentes e menores são numerosíssimos e, por outro lado, a sociedade é de um rigor quase medieval no tratamento dispensado à mulher que teve a desdita de perder o seu 'status virginitatis'.

Em Cabo Verde a sedução de menor ocorre também com freqüência e, no caso de Bèlinha, dá-se com seu consentimento, apesar de o desenrolar da trama literária ferreriana pautar-se pelo viés preventivo, centrado nos conselhos maternos sobre os cuidados com o corpo, a atenção dos perigos das apelações de experientes rapazes que consideram as jovens apenas como presas fáceis para seus deleites. A dança, corpos colados, propicia o contato amoroso: 
A rapariga estremeceu nos seus braços. Um sem-vergonha. Miguelim, porém, era experimentado e moço conhecedor de mulheres. Sabia fazer as coisas como tipo batido de correr mundo... Corpo com corpo face na face bacia com bacia sexo no sexo - era a música que os levava naquele ritmo brando e pecaminoso? Ou não era? Que era? (FERREIRA, 1972a, p. 37).

Os bailes nacionais de São Vicente eram tradição cultural crioula e facultavam aos rapazes a abordagem das raparigas.

O tema da sedução via crescendo na estória, envolvendo a protagonista e permitindo ao leitor entrever a sua desventura futura. $\mathrm{O}$ caráter didático e preventivo da narrativa concentra-se na figura da mãe, que tenta proibir a filha de transitar do espaço privado da casa para o espaço mundano (público) do "baile", a fim de evitar que aquela, por inexperiência, trilhe caminho semelhante ao percorrido pela figura materna. Contudo, os apelos da filha enfraquecem seu poder de decisão, e a mãe permite que Bèlinha siga ao encontro do seu destino:

A noite veio e nela um sabor uma morabeza um bafo de desejos alcançados. E o baile de Zé de Canda crescia nas horas tardias dessa noite luminosa... Miguelim estreitou-a mais. E o tempo que a estreitava mais, ciciou-lhe: 'Bèlinha, eu quero falar-te. Estás a ouvir? Estás a ouvir, Bèlinha?' O corpo do rapaz colado ao seu, deixava que ele a dobrasse toda pela cintura... A noite alongava-se. Os corpos excitavam-se e a todos percorreria o desejo de liberalidade. Tornar essa noite numa noite em que cada um fizesse as desproposentezas que lhe apetecesse... Miguelim estreitou-a. Ela foi ouvindo as palavras, cedendo pouco a pouco numa tensão de desespero e deliciosa entrega. Bèlinha, nhá crecheu. $O$ trompete, no auge da sua loucura, abafou as palavras da moça. Sumidas dolorosas. Submissas. 'Não. Não' A voz da noite sabe como intentação (Ibidem, p. 34-38).

A pedofilia em Cabo Verde, hoje, é considerada crime; todavia na época da escrita do conto (1972), não se configurava como delito que merecesse ser denunciado pela vitima ou por seus responsáveis; estes, na maioria das vezes, mantinham-se (e ainda mantêm-se) silenciosos, temendo comentários discriminatórios à perda do status virginitatis, ou quiçá, descasos dos órgãos competentes.

Mediante tal mentalidade, o abuso era cometido e acobertado. Atualmente, os órgãos competentes têm-se mantidos em alerta e os casos de pedofilia têm 
sofrido denúncias freqüentes, fazendo-se cumprir os regimentos jurídicos adequados a cada caso. Segundo as palavras da Juíza, Desembargadora e Presidente da Comissão Nacional para os Direitos Humanos Vera Duarte (2007, p. 64):

[...] na Declaração Universal dos Direitos do Homem, a que vimos nos referindo, e que expressamente consagra que a criança tem direito a uma ajuda e a uma assistência especial em ordem a proteger os seus direitos... Cabe realçar que, desde a Declaração Universal de 1948 e mesmo antes, até esta Convenção de 1990, a Comunidade Internacional não deixou de prestar atenção à situação específica da criança devido, fundamentalmente, à sua falta de maturidade física e intelectual, o que a torna particularmente vulnerável.

A literatura, como veículo de comunicação, pode constituir um meio para a conscientização das famílias e das jovens quanto às conseqüências da iniciação prematura das atividades sexuais, como a gravidez precoce, a incidência de AIDS, a prostituição infantil e a discriminação social, a par das suas funções diretamente ligadas à fruição das qualidades artística dos textos.

Em suma, o conto expõe a inserção precoce das mulheres cabo-verdianas no universo dos objetos de consumo, revelando um olhar que as encara como vítimas passivas (como ressaltava Michelle Perrot) do homem predador. É sob este parâmetro que Manuel Ferreira apresenta Bèlinha.

O conto Uma flor entre os cardos ${ }^{5}$ também aborda o tema da exploração sexual das jovens e o narrador discorre sobre a experiência de uma moça de treze anos de ter a sua "inocência" roubada em virtude do envolvimento emocional e da cessão aos apelos carnais. A protagonista, "uma flor do mato", que vivia com os pais em Chão de Alecrim, é assim apresentada: "Rosita, treze anos apenas, e a inocência no riso e nos modos" (FERREIRA, 1972b, p. 131). Fisicamente, "os olhos [são] duas amêndoas, cabelo negro, um pouco escorrido, cinturinha fina, túmidos seios a crescerem como papaias, não havia homem que não a mantenhasse. Disputada os bailes, ao fogo da morna" (Ibidem, p. 133).

\footnotetext{
${ }^{4} \mathrm{O}$ cardo (cactus) pertence à família das Asteraceae e cresce em locais rochosos, sobretudo em terrenos barrentos, podendo ser encontrado na forma selvagem ou cultivada em Portugal, nas zonas meridionais e ocidentais do mar Mediterrâneo, no norte da África, nos arquipélagos da Macaronésia (Cabo Verde, Madeira e Canárias) e na Argentina.
} 
O narrador a retrata como "crioulinha amadurecida", "de rígidos seios" e "corpo sabinho", demonstrando o olhar patriarcal que encara a mulher como deleite para o seu prazer (seios como "papaias", "sabor do corpo" (Ibidem).

Tal como Bèlinha, personagem do conto anterior, Rosita reivindicava junto à mãe a permissão de frequentar os bailes de São Vicente, símbolo de diversão e alegria. A sensualidade da dança a dois cola-se ao núcleo semântico do baile, indiciando a transformação da personagem feminina face aos apelos carnais.

O estilo didático é vislumbrado em diversos trechos desse conto, não fugindo à regra a preocupação do narrador-conselheiro que se cola à fala da mãe na conscientização dos perigos iminentes para as adolescentes sonhadoras que se entregavam aos ritmos das mornas e das coladeiras: "Crescia, enfeitava-se e a mãe andava de olho grilido. E lá sabia. São Vicente estava cheio de desgraça. De moças mocratas por todos os cantos. Um dia passaram no Lombo e viram-nas [...] Dançam coladeira nuinhas para a gente de bordo" (Ibidem, p.132).

Lembramos que o Porto Grande, no início do século XX, com sua estrutura portuário-carvoeira, vai ajudar a configurar a população da cidade do Mindelo como espaço masculino de trabalhadores da estiva, contrabandistas, marinheiros de passagem que frequentarão os botequins e bordéis, guiados cicerones ou "meninos de ponta de praia" que agenciarão as prostitutas. A atividade da prostituição ultrapassará, contudo, o espaço do Porto, como podemos observar o conto de Manuel Ferreira, pois também Chão de Alecrim, lembra Rosita, está repleto de “menininhas dando o corpo pelos becos escuros pelas praias pelas esquinas [...] já ela estava farta de saber (Ibidem).

Os conselhos da mãe recomendam "juízo" com vista a casamento.

Do contrário, ser mocrata ou "menina-de-vida", "menina arregaçada", "com doença ruim", "esperando homens" e freqüentadora do espaço são-vicentino reservado às prostitutas, o Lombo (Ibidem) é um futuro que as mães cabo-verdianas, a todo custo, tentam afastar de suas filhas. Rosita, personagem cuja estrutura familiar condiz com os padrões sociais esperados pela cultura patriarcal crioula ("moça séria", "esquiva" aos rapazes, sua tarefa maior era ajudar a mar lavadeira, cf. Ibidem, p. 131, 133,134), opõe-se a Bèlinha, que vivia apenas com a mãe. A ausência de pai no lar, no caso desta, parece conduzir a uma leitura de que, a esta família retratada nos anos sessenta (tempo da narrativa, em plena ditadura colonial), 
faltaria uma autoridade mais firme para que as regras comportamentais fossem cumpridas. Sem a ação do poder paterno, a jovem Bèlinha poderia ter mais liberdade e mais poder de convencimento da mãe, já vitimizada (na ótica masculina do conto) em época passada pelo mesmo tipo de abordagem afetiva:

Mamãe lembrou-se do seu tempo de moça. Das noites de amor lá pelas ribeiras do Paul lá pelo Tarrafal do Monte Trigo. Lembrou-se dessas noites de baile e todo o seu tempo de moça a dominou sem apelo (FERREIRA, 1972a, p. 33-34).

A repetição do comportamento por gerações pode evocar também um "destino incontornável", na ótica masculina da narrativa ferreiriana, para as jovens que cedo começam sua vida sexual em Cabo Verde.

Contrapondo-se a Bèlinha, Rosita, valorizando a presença paterna em casa, de certa forma espera mais respeito por parte dos rapazes, no que diz respeito à aproximação afetiva. Esta base familiar, neste conto, afastaria de seu caminho rapazes de má conduta, ou aqueles que o fizessem com má intenção: "Não era menina de liceu, não. Menina do povo, sim, mas queria casar, arranjar namorado que não fosse para entreter" (FERREIRA, 1972b, p. 134). Por sua conduta esquiva, Rosita é "uma flor entre os cardos", protegida por espinhos que, como veremos, não Ihe darão afinal a segurança esperada.

Também na ficção ferreiriana, a personagem feminina Rosita vai sofrer uma transformação, com o aparecimento do "furriel ${ }^{6}$ alto moreno", ora de "voz branda insinuante", ora de "voz de inferno" que, ademais, falava crioulo também: as formas da moça "tinham-se arredondado" e as promessas de Rui ("vestidos finotes", casa montada, criada, "óleo para o cabelo", "sapatos como os da Joana") começam a tentá-la (Ibidem, p. 135).

Em certa manhã, queixando-se de dores o corpo _ estratégia psicológica de abordagem _, o furriel aborda Rosita:

Acariciou-lhe os braços pôs-lhe as mãos nas coxas. Ela consentia. Qualquer coisa lhe tomava o corpo prendendo-a ali como mel.O

\footnotetext{
${ }^{6}$ Furriel: equivale a um sargento, só que na cavalaria.
} 
furriel conversava, dizia graças numa voz do inferno. Insistindo, acariciando, ela percorrida duma delituosa sensação, que Ihe restava? (Ibidem, p. 135-136).

Rosita sucumbe ao toque e ao gesto de Rui, como "fruto maduro". Seu pai, "homem de seu grogue e de sua farra", descoberto o passo dado pela filha, dirige-se à casa do "tropa" e o acusa: "O senhor, sabe, Rosa não é mais moça virgem. $O$ senhor desgraçou-a" (Ibidem, p. 136).

A filha, outrora considerada séria, passa a ser taxada imoral pelo pai, que exige uma reparação do furriel, que se "esquiva". A estratégia do pai para uma pseudocompensação para Rosita, será a chantagem: "O senhor é tropa. Se quiser, vou fazer queixa no seu quartel e o senhor vai para a cadeia" (Ibidem, p. 137).

Por fim, Luís Cândido (observe-se a ironia do sobrenome) vende a honra da filha ao furriel por trezentos escudos (cerca de 6 reais), além de depreciá-la:

Eu sei. Mal está feito, está feito, não tem remédio, não senhor, minha filha não é moça para o senhor, eu sei. Senhor é homem de posição, eu sei. Se me der trezentos escudos, pronto, negócio fica direito. [...] E quando Rui Armando Ihe estendia as notas, o velho, sem pestanejar, rectificou a parada.

Senhor Rui, o senhor me dá quinhentos escudos. Trezentos é pouco. O senhor sabe (Ibidem, p. 137).

Manuel Ferreira enfoca, também neste conto, a pedofilia cometida pelo soldado ("Tinha o furriel na mão. Desonrar moça menor é coisa perigosa para um tropa [...] se eu quiser ponho o senhor na cadeia"; ibidem, p. 138), crime que, por sua vez, associa-se com a responsabilidade familiar e social e com a denúncia do descaso paternal em benefício de terceiros. O caráter do pai da protagonista e seus desvios de conduta são antecipados pelo narrador, que o associa ao grogue, à farra, ao botequim: "Dia de domingo quem queria vê-lo ia ao botequim" (Ibidem, p. 136). Portanto, a conclusão a que o leitor poderá chegar é que, com tal pai a conduzir a família, Rosita provavelmente não teria um futuro promissor, apesar dos cuidados da mãe. 
Como citado anteriormente, a pedofilia sempre se constituiu como ato degradante e criminoso em Cabo Verde, sendo, todavia, as possíveis denúncias silenciadas em nome da ordem e da honra familiar.

A cena final do conto reveste-se de tragicidade: Rosita, "que fora a pequena rainha do Chão de Alecrim", agora, é "sensível aos nordestes de março e às mornas de Bèléza", o que sugere sua vida instável e a sexualidade aflorada; o pai ruma, com o preço da honra da filha, diretamente ao botequim: "saiu do quarto do furriel Rui Armando e dali foi à cata de companheiro no botequim Scotland Bar" (Ibidem, p. 139).

\subsubsection{TEOBALDO VIRGÍNIO}

Além dos escritores estudados, Teobaldo Virgínio (Virgínio Assunção Nobre de Melo), poeta e romancista, nascido a 21 de maio de 1924, na vila de Ponta do Sol, ilha de Santo Antão, e atualmente pastor nazareno residente nos EUA, em Brockton, apresenta como temática o cotidiano dos homens que vivem da pesca, as tradições do povo cabo-verdiano, os tabus sociais..

Irmão do escritor Luís Romano, falecido recentemente, Teobaldo Virgínio foi galardoado com a Insígnia Municipal de Mérito pela Assembléia Municipal de Ribeira Grande, Santo Antão, em 17 de janeiro de 2010. Segundo o presidente da Câmara Municipal de Ribeira Grande, a homenagem a Teobaldo Virgínio é "justa pela grande contribuição para, através da sua pena, levar Ribeira Grande a todos os cantos do mundo"'.

Também seu irmão, o escritor Luís Romano, apresenta no poema "Vida" temática semelhante à que ora examinamos (Clima, 1963):

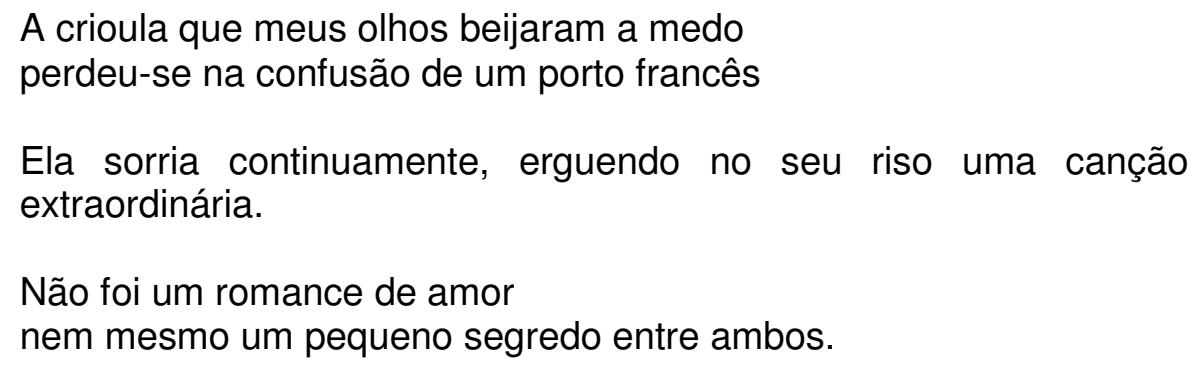

\footnotetext{
${ }^{7}$ Em www.expressodasilhas.sapo.cv/pt/noticias.
} 
Somente, quando Ela falava ao pé de mim, eu sentia:

um aprazível devaneio

pela maravilha escultural duma Mulher Perfeita.

Depois,

a Vida separando Nós-Dois

a confusão, os ruídos, os braços agitando-se

e o vapor levando para outros mares,

outros portos,

a graça, o mistério, o perfume e os cantares

da crioula que meus olhos beijaram a medo

no tombadilho daquele vapor francês.

O conto de Teobaldo Virgínio Beira de Cais, publicado em Claridade 9, 1960, apresenta pescadores da beira do cais da Ponta do Sol e suas mulheres, que não fogem à descrição do objeto de desejo. São retratados seus lindos seios pontiagudos, suas pernas grossas e as qualidades de parideiras. Além disso, também são apresentadas as transformações femininas de gerações de mulheres de marinheiros, pelas lutas constantes vividas na beira do cais, limpando e carregando os grandes balaios de peixes, desfigurando-se ao longo tempo pelas inúmeras gestações e pela prostituição.

História da beira do cais é a história de Pedro Dical e Nenê de Pito. De Nenê de Pito e de Pedro Dical, que é a história da vida de todo o marinheiro da beira do cais da Ponta do Sol. E também das filhas e netas de Chica Guida, nascidas para serem companheiras dos marinheiros. Boas mulheres de pernas grossas e seios pontiagudos, parideiras. Das filhas de Maria Joaquina, uma preta forte, que fumava cachimbo. Mulheres da beira do cais, que raramente se casam, vivendo livremente com os marinheiros. [...]

$\mathrm{Na}$ beira do cais, mulher que o marinheiro leva para sua casa morar é mulher legítima, mesmo sem terem ido à igreja. Mas com Henrique foi diferente. Henrique casou. Casou com Xanda, mas vive com Xencha. Xanda enganara-o (VIRGíNIO, 2001, p. 458-460).

A importância da virgindade da mulher, na narrativa em exame, é levada às ultimas conseqüências, exigindo-se a comprovação de sua inexperiência e pureza. Também a fidelidade matrimonial é dever feminino, enquanto que a virilidade masculina provada com diversas mulheres é aceitável pela sociedade. A recíproca, porém, não é verdadeira: as mulheres que traem são punidas com a discriminação e difamação: 
$\mathrm{Na}$ mesma noite do casamento Henrique bateu à porta de Xencha. Vinha com uma das pernas das calças arregaçada em sinal de traição e acompanhavam-no muitos marinheiros amigos naquela noite memorável de Cabouquinho de Tinta. A madrinha da noiva, apesar da atrapalhação, havia-se adiantado a fazer a cama revolta para que Henrique se deitasse com Xanda outra vez. [...] Entretanto, enquanto a madrinha procedia ao arranjo da cama, nhá Joaquina e outras velhas, para remediar, degolaram à pressa um porquinho da Índia e mancharam os lençóis com sangue, Henrique embora constrangido a se deitar pela segunda vez, não foi ao bote. Xanda havia-se deitado primeiro com o padrinho, já não era menina (Ibidem, p. 460).

Percebe-se nessa passagem a supervalorização do status virginal, assim como as estratégias de resistência das velhas senhoras à ordem patriarcal, burlando as desiguais de conduta exigidas às mulheres. A personagem Henrique, por sua vez, representa o pólo conservador dos ditames patriarcais, levando sua indignação às ruas como ato de punição para a esposa.

O detalhe de uma das pernas da calça arregaçada, segundo o narrador, denuncia o delito cometido pela noiva, remontando às crenças e costumes populares arraigados dos povos ilhéus, que acarretam a difamação da jovem.

De acordo com João Lopes Filho (1996, p. 152- 153),

Temos assim, que o sentido de honra encontra-se profundamente inculcado no homem cabo-verdiano e constitui um dos valores fundamentais por que esta sociedade se rege (...). No caso do adultério, a honra ferida exige uma reparação, uma vingança, que pode ir desde a expulsão da mulher até à morte do (s) culpados. Convém frisar ainda o papel importante da mulher na manutenção da honra ou desonra (vergonha) na família cabo-verdiana.

Outra personagem feminina que Teobaldo apresenta é a parteira, mulher sem conhecimentos técnicos ou médicos, que aprenderam seu ofício através da transmissão tradicional; à medida que se vai tornando mais velha e impossibilitada de exercer a prática, já está preparando outra mulher para assumir seu posto, como esclarece Lopes Filho (1995, p. 23):

Daí que, na maioria das vezes, o parto fosse acompanhado pela velha parteira local, considerada mestra no assunto e autoridade quase infalível, apesar de nunca ter estudado nada sobre a matéria 
(por vezes eram analfabetas), ou ter sido ensinado por qualquer especialista. Todo o seu conhecimento advém da experiência ou adquirida na prática.

Quanto à metamorfose física feminina, pode ser também observada nesta narrativa:

Pedro Dical é um dos grandes patrões da baía.[...] Genoveva já lhe pariu 10 filhos, as pernas cheias de varizes de tanto carregar o cais, de tantos partos. Pedro Dical tem mais filhos noutras mulheres da beira do cais (VIRGíNIO, 2001, p. 459).

Segundo o narrador deste conto de Teobaldo Virgínio, todas as mulheres de beira de cais têm "o mesmo destino: deitarem-se com os marinheiros para parirem outros marinheiros (Ibidem p. 461).

O baile é outra constante dos contos escritos por homens em Cabo Verde, sempre indiciado a possibilidade de afloramento da sexualidade das mulheres:

Às vezes há baile. Toi de Batalha, remador de proa, é quem toca e canta à viola nas mornaduras de Cabouquinho de Tinta. Filhas de marinheiros coladas aos marinheiros executando morna num capricho de sangue. [...] Marinheiros rolando na areia com as moças da beira do cais (Ibidem).

Nesta movimentação ancestral "das mulheres do cais, meninos sem pai” (p. 463) encerra-se o conto, enfocando os homens "à noite, depois de grogue e cachupa, consolando-se com suas mulheres da beira do cais" (Ibidem).

$\mathrm{Na}$ força de reprodução, no trabalho de disputar as cargas de bordo ou o peixe para venda, na prostituição resumem-se as funções das mulheres caboverdianas retratadas neste conto de Virgínio.

\subsubsection{OSWALDO OSÓRIO}

O ficcionista e poeta Oswaldo Osório, nascido na ilha de São Vicente, a 25 de novembro de 1937, revelou-se nos anos setenta como prosador ao publicar na 
revista Raízes um conjunto de pequenas estórias da série "Amores de Rua". Desta, selecionamos dois pequenos contos, "Borboleta Evadida" e "Rebindita", extraídos do livro Nimores e Clara \& Amores de Rua, publicado em 2003, na cidade da Praia, Cabo Verde.

No primeiro, o escritor, recorrendo ao narrador-personagem, explora 0 universo amoroso, com foco nas mulheres amadas. A retratada é Guida, ilhoa "com Paris nos olhos" (2003, p. 110). Sua trajetória começa a ser desvendada: "sumiu com o Tutchinho naquela carrinha, não viste? Não é de hoje que eles têm a sua água-suja..." (Ibidem); é recambiada para sua ilha de origem, pela administração, em virtude de má conduta ou ofensa à moral pública; trai Tutchinho, que lhe dá um flagrante. Seu destino final é a emigração para Lisboa e o cais da despedida, "deserto" e "envolvido na escuridão" _ índice de seu futuro enegrecido de "borboleta evadida" _ centraliza o close up da cena final desta narrativa breve.

"Rebindita", título de outra narrativa breve de Oswaldo Osório, traz-nos o ambiente do cais na estória de uma "menina de vida" (2003, p. 119) que parte, depois de um relacionamento com o narrador-personagem: "Agora que noites e noites se sucederam à primeira de Carnaval em que a possuí graças a um encontro inesperado no Éden, já vai por um ano, censuro-me por não ter ido ao cais despedirme dela" (Ibidem).

O contexto do relacionamento ocasional com o homem casado gira em torno do baile, do Carnaval e do Éden Park, a mais importante sala de espetáculos da história de Cabo Verde.

$\mathrm{Na}$ ausência do homem ao encontro marcado num baile, a moça dorme com outro por vingança, comportamento que o amigo Dante, com quem dialoga o narrador-personagem, considera esperável para uma prostituta: "Procedeu como menina de vida que é. Mais tarde ou mais cedo havia de acontecer. Trazem-no no sangue, é como se fosse hereditário [...] é uma...” (Ibidem).

O argumento biológico, que durante muito tempo foi utilizado para a distinção teórica de gênero uma ótica machista-positivista na trilha do determinismo de Hippolyte Taine, definindo a mulher como ser passivo ou como pólo diabólico da relação amorosa, resume aqui a linhagem feminina do comportamento da Rebindita, 
que o amante resolve chamar de Vendetta, sinônimo de vingança, e ainda dedicarIhe um conto.

O tratamento pejorativo _ "é uma...”_ alia-se à ótica machista na narrativa.

As descrições da personagem feminina (o nu feminino exposto para a fruição masculina) ressaltam as reações que sua sensualidade desperta no narrador-personagem:

Se a visses nua, se te queimasses no calor do seu corpo, não terias tanto desprezo [...]. Não é preciso dizer-te que ela dança a coladeira fera como nenhuma. [...] ao pôr-se nuínha: seios de virgem, rapaz, tesos e cónicos como açúcar de forma da Praia, da cor do açúcar mascavado, que chupei em ponto de rebuçado fervendo dentro de mim, ao sentir-Ihes a consistência. $O$ ventre $d$ meia-lua onde se encastoava ligeiro acidente que me passava quase despercebido, o umbigo, liso e a adelgaçar-se era também de mulher que nunca tinha engravidado. Vibrátil e de carícias de dedos de seda. Mínimo toque a enlanguesce. Dá-se entre gemidos, afagos e, se morde, fá-lo para desencadear novas torrentes de prazer (OSÓRIO, 2003, p.120-121).

A dança da coladeira (ritmo cabo-verdiano extremamente sensual) complementa o quadro da mulher retratada como fêmea, fantasiada de "coelhinha" no baile de Carnaval. A percepção do narrador-personagem (dado a farras e aos bailes do Miradouro e do Tolentino, tradicionais em Cabo Verde) de que ela "podia ser qualquer daquelas meninas do Curral" (Ibidem, p. 121) evidencia como a tinha encarado, logo de início, como prostituta ou objeto de desejo.

\subsubsection{ANTÓNIO AURÉLIO GONÇALVES}

António Aurélio da Silva Gonçalves, nascido na ilha de São Vicente, em 1901 e falecido em 1984, professor do ensino secundário e escritor renomado, sobretudo no que concerne ao espaço mindelense cujos temas abrangentes vão do pessoal ao social, enfatiza a decadência familiar, primando por retratar as personagens femininas. 
Autor de diversas novelas tais como Recaída, cujo primeiro capítulo foi publicado em 1947, no número 5 da Revista Claridade, sua obra é assim definida por Arnaldo França:

A partir de Recaída, na sua primeira versão, António Aurélio Gonçalves foi publicando algumas novelas em que o meio mindelense é minuciosamente analisado, num espaço físico que na sua maior parte se situa na periferia da cidade e, neste caso, indissociável do espaço social criado pelas características econômicas, culturais e morais que condicionam o comportamento e, quantas vezes, o destino das personagens (FRANÇA, 2003, p.11).

Dentre suas obras constam Noite de Vento, Terra da Promissão, Pródiga, O enterro de nhá Candinha Sena e Burguesinha, todas com temáticas em que a figura feminina é retratada. A suas estórias focalizam as personagens que povoam e habitam São Vicente, preenchendo os espaços da ilha com seus enredos, amores e desamores.

António Aurélio Gonçalves descreve sentimentos, tanto masculinos quanto femininos, deste universo humano, revelando fraquezas e avaliando-as.

Dos amores recortados pelo escritor, muitos não passam de traições, fraudes, relações mantidas às ocultas, numa atmosfera do falso, incerto e ilusório.

Norteado pelas doutrinas naturalistas, especialmente a teoria determinista enunciada por Taine, que condiciona a personagem à hereditariedade e ao meio, cada texto resume uma existência e é consequência de uma atitude perante a vida, determinada por um caráter que se explica por um complexo de influências.

Uma certa fatalidade, misturada à ironia, enlaça opções estéticas e éticas da escritura aureliana, que opta por centralizar o espetáculo da cidade num eixo comum, o sexo (GAMA, 2009, p. 42) e, acrescentamos, a sedução.

De Noite de Vento (1985), trataremos com maior ênfase a novela "Virgens Loucas", cujo título dialoga com a epígrafe extraída do capítulo vinte e cinco do Evangelho, Livro de Mateus. Também neste texto as virgens não foram previdentes, não tinham azeite para as lamparinas e, quando o noivo chegou, não estavam 
presentes para recebê-lo. As prostitutas Betinha, Nuna e Domingas não guardam petróleo para os candeeiros e, portanto, não provêem o seu futuro.

Segundo Maria Aparecida Santilli (SANTILLI, 2007, p,128),

uma epígrafe remete a outro texto com o qual, portanto se relaciona, é já um índice complicador de elaboração da trama. A fonte a que recorre António Aurélio Gonçalves é ancestral e leva a imaginar a articulação desta narrativa com a função de instruir. Por iluminar ou fazer ver claro na concretude da prática aquilo que as parábolas, no fundo, teorizam. Aqui se bebera nas Escrituras, mais pontualmente no Novo Testamento, de cujos quatro evangelistas se evoca o primeiro Mateus, tido por certos exegetas como o 'mais amplo e ambivalente', em cujo evangelho se evidenciaria esta preocupação com a negligência.

António Aurélio Gonçalves transporta a parábola bíblica para o contexto cabo-verdiano da novela, personificando as cinco virgens das escrituras nas três prostitutas negligentes. Acreditamos ser pertinente subscrever a passagem bíblica, para se compreender melhor a trama das quais estão inseridas três prostitutas da novela aureliana.

Quando, à meia-noite, se ouviu gritar: Eis aí o esposo, saía a recebê-lo;

Então se levantaram todas aquelas virgens, e prepararam todas as suas lâmpadas.

E disseram as fátuas às prudentes: Dai-nos do vosso azeite, porque as nossas lâmpadas se apagam.

Responderam as prudentes, dizendo: Para que não se suceda, talvez, faltar-nos ele a nós e a vós, ide, antes, aos que vendem, e comprai o que haveis mister.

$E$ enquanto elas foram a comprá-lo, veio o esposo; e as que estavam apercebidas entraram com ele a celebrar as bodas, e fechou-se a porta.

E, por fim, vieram, também, as outras virgens, dizendo: Senhor, Senhor, abre-nos.

Mas ele respondendo, Ihe disse: Na verdade, vos digo que vos não conheço (Evangelho segundo Mateus, 25. In: GONÇALVES, 2001, p. 36).

O ensinamento moral da parábola sintetiza que a prudência nos guarda de males futuros. Por meio do recurso ao texto bíblico, Gonçalves retrata a "necessidade de [as personagens Betinha, Nuna e Domingas] adquirirem uma visão mais nítida" (GAMA, 2009, p. 69) de suas vidas, uma vez que estão imersas no 
universo sem perspectivas da prostituição, segundo a ótica masculina evidenciada na novela.

Recortadas por um viés degradante, de exclusão de carências afetivas e materiais, as personagens buscam na noite escura ajuda dos comerciantes para adquirir petróleo para seus candeeiros, sem sucesso.

Assim o narrador apresenta as três prostitutas:

As três raparigas tinham passado a tarde juntas no quarto de Domingas, numa viela do Lombo. Betinha era a única engraçada: mulata, de corpo ainda jovem, fisionomia delicada e feição que destacava contrastando com a tonalidade escura da pele - os olhos de pupila verde com brilho de primitiva [...] Nuna estendera-se em posição inversa: apoiava a cabeça no couce; tinha os dedos cruzados sobre o peito e as pálpebras descidas, com o ar de quem encontrou sítio e vagar propícios a um repouso completo. Domingas girava pelos quarto cantos, a tratar, como dona da casa, das suas ocupações. Era a mais feia: baixa, bochechuda, macilenta, caminhando para obesa, duramente castigada pela desgraça. $\mathrm{O}$ quartinho era pequeno - um buraquinho onde meter a cabeça, como é costume dizer-se - com a porta de entrada, janela para a rua e mais uma serventia para o quintal (GONÇALVES, 2001, p. 36).

As três mulheres negligentes são focalizadas num espaço fechado (um quartinho "pequeno", "um buraquinho", numa viela escura iluminada apenas por uma lâmpada qualificada como "triste, impotente" (p. 39). A viela é definida como "espaço tenebroso" (Ibidem, p. 39) pelo narrador e por Betinha como "lugar medento" (lbidem), e o destino das personagens, como um destino fechado: a porta, a última que poderia trazer a luz _ a da mercearia de Léla de Memente _ é fechada para elas com "ar enigmático, intransponível" (Ibidem, p. 55) e sob acusações.

Talvez a mensagem do conto fosse a busca da luz como redenção das suas almas pecadoras (GAMA, p. 69), mas as três regressam à casa de Domingas para dormir na escuridão: "Sim, hoje dormimos no escuro. Não tem remédio..." (GONÇALVES, 2001, p. 57).

Cresce em Betinha "um sentimento de irremediável desastre, de vida sacrilegamente poluída (em contraste com o sacro da epígrafe)" que lhe gera um grito de agonia: "Que fiz da minha vida?" (Ibidem, p. 55) A certeza da repulsão que causam as mulheres-borboletas que tentam se aproximar da luz (lbidem), 
personificada na aparição de um "companheiro que se deseja sem interesse", "para fazer esquecer a vida, a desgraça e o seu horror" (Ibidem).

No entanto, a fala de Domingas a Betinha, ilumina com uma réstia de luz este destino fatal: "Tua mãe tem razão. Tu estás novinha, não és nenhum peixe podre. A mim, já estou velha. Tu, sai do Lombo, encontras marido [...], ele põe-te casa com luzes bonitas..." (Ibidem, p. 42). Como se pode observar, as luzes bonitas iluminam o campo do casamento, enquanto a escuridão domina o da prostituição, numa perspectiva da escritura masculina que valoriza o universo privado da família como espaço feminino.

O espaço das três prostitutas, mesmo limpo ("espanejado, esfregado"), "parecia recoberto de qualquer substância que não era fácil definir: trazia à lembrança idéias como humidade, impureza empastada nas paredes, amolecendo os trastes, desgastando, impregnando o ambiente e que nenhum cuidado poderia limpar" (Ibidem, p. 36). Seus sentimentos, revolta no fundo dos olhos (p. 39), culpa (p. 38), mágoa (p. 35) e tristeza (p. 52) a percorrer toda a narrativa.

Uma vez mais, nas noveletas de António Aurélio Gonçalves e nos textos masculinos do corpus aqui apresentados, o submundo da miséria física e moral e a condição subalterna da mulher evidenciam-se como temas. "O Lombo", lugar das raparigas que lá convivem, e onde se situa o quarto de Domingas, marca a pobreza e a vitimização pelas quais passaram (e passam) as meretrizes da ilha de São Vicente, em Cabo Verde.

Percebe-se esta novela a inquietude, a vergonha e a desonra que as prostitutas representam ao seio familiar, lembrando João Lopes Filho.

A luminosidade do universo da casa ("_Ó como a casinha de nhâ Romana brilha! Casa é assim. Algum dia, Deus há-de me dar uma igual?", sussurra Betinha, p. 41) é, mesmo que seja por um momento ("para sossegar, por esta noite, no quarto de Domingas", p. 47), o repouso e a esperança perseguidos (para "assentar" da "canseira de vadiar pelas ruas à caça de homens", p. 49), sem sucesso, pelas personagens femininas; o casamento é a saída apontada pela narrativa e pela mãe de Betinha, para que as moças se enobreçam no espaço privado, sosseguem em definitivo, como nhâ Romana, que achou um "marido que dá-lhe tudo", que Ihe "comprou casa, pôs-lhe obras": 
A minha intenção era sair daqui para a casa da Mamã. [...[ Mas ela tem o seu defeito: recebe-me sempre com guerra. Ela não tem outra coisa senão: 'Sai desta vida! Sai desta vida! Não me apareças 'li em casa se não saíres desta vida!' [...] Não é preciso ela dizer-me: eu sei que tenho culpa. Mamã não quer compreender que cada um vem a este mudo com um destino (p. 38 e 41).

Enfim, resume Betinha: "Governo da casa é que é tudo" (p. 46).

O conto termina com uma luz de esperança, na fala e na vontade desta personagem: "Quero ter a miha luz!" (p. 57). 
Kiki Lima - Graça de voar

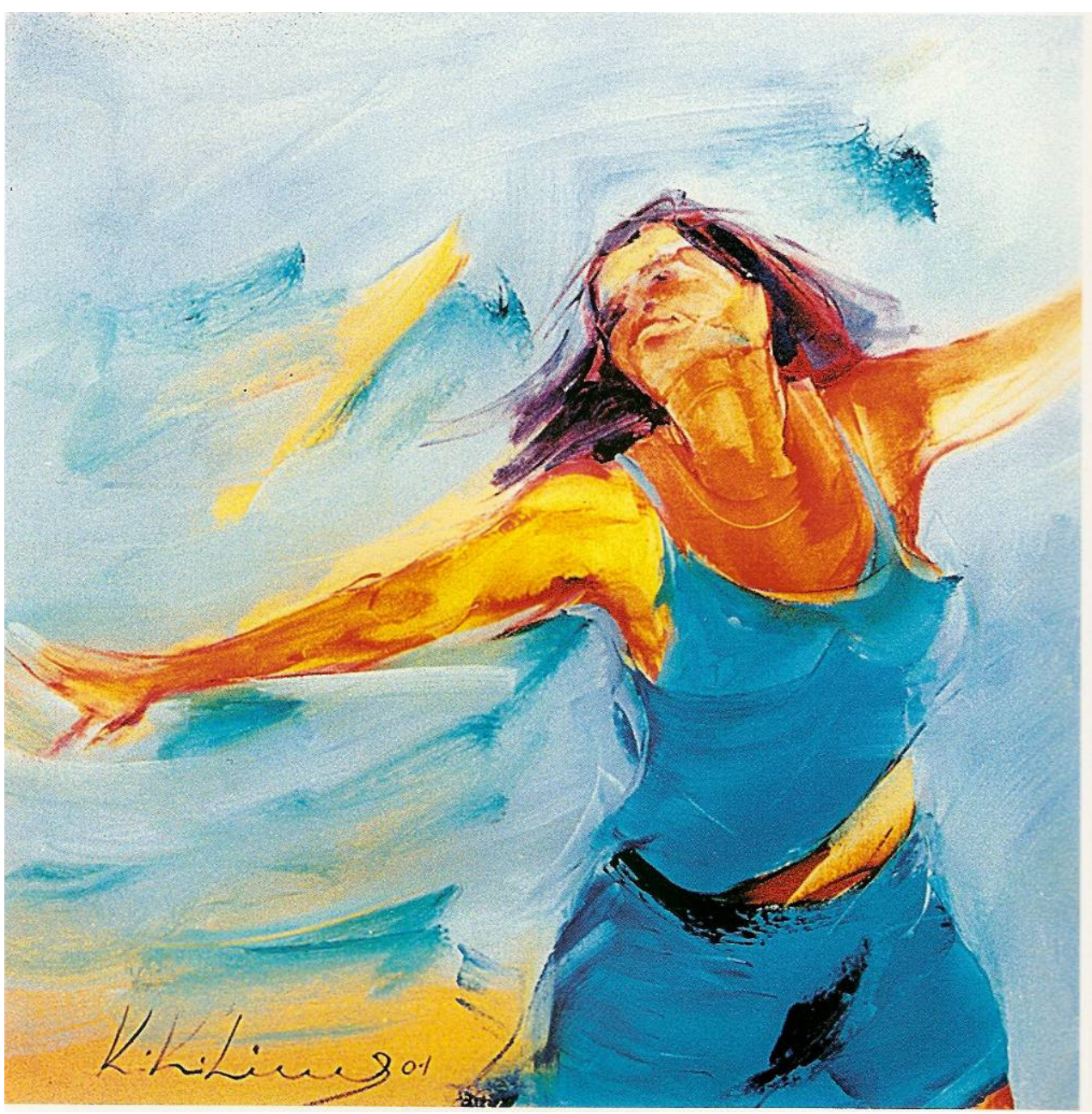




\subsection{A PRODUÇÃO FEMININA REVELA AS MULHERES CABO-VERDIANAS}

[...] ter que assumir de agora em diante a inédita autoria do Feminino. Autoria que se impõe quando elas não se reconhecem mais em imagens, vivências e representações que ecoavam o "eterno feminino" dos poetas, quando aceitam a travessia da ambiguidade como preço de experiências desejadas e temidas e se dispõem a encarar o vazio como ponto de partida.

Rosiska Darcy de Oliveira

A autoria do feminino, segundo Rosiska Darcy de Oliveira (1993, p. 13), é, sobretudo, a de "uma linguagem para dizê-lo" e a emergência das mulheres à criação cultural e ao universo da literatura foi considerada, segundo a teórica, um "crime político" (Ibidem, p. 114).

Hélène Cixous, em $\mathbf{O}$ riso da medusa, sintetiza a tarefa das mulheres: "escrever-se, escrever sobre as mulheres e levar as mulheres à escrita. [...] devem colocar-se no texto _ como no mundo e na história _ por elas mesmas" (apud OLIVEIRA, p. 130).

O feminismo possibilitou às mulheres transgredir uma ordem em que 0 masculino definia o feminino como seu avesso (Ibidem, p. 13) ou como um apêndice, com base em toda uma história de discriminação e exclusão.

Como ressalta a pesquisadora Rosiska Oliveira (Ibidem, p. 16), interrogar a ciência e a arte como esforço de alteridade e desconstrução faz parte de um movimento de feminização da vida que leva as mulheres "a exercer no político a lógica do feminino" (p. 28).

Para Teresa de Lauretis (1994, p. 207):

A primeira limitação do conceito de 'diferença sexual', portanto, é que ele confina o pensamento crítico feminista ao arcabouço conceitual de uma oposição universal do sexo (a mulher como a diferença do homem, com ambos universalizados: a mulher como diferença pura e simples e, portanto, igualmente universalizada (o que torna muito difícil, se não impossível, articular as diferenças entre mulheres e Mulheres, isto é, as diferenças entre as mulheres ou, talvez mais exatamente, as diferenças nas mulheres. 
Assim, o contexto que ora examinamos, o cabo-verdiano, interessa-nos observar como as autoras se escrevem e escrevem sobre as mulheres em Cabo Verde, como feminizam a vida, como denunciam e propõem a superação das formas de exclusão e discriminação social das mulheres.

Elódia Xavier esclarece que, a partir da estreita relação entre linguagem e sujeito, "quando uma mulher articula um discurso este traz a marca de suas experiências" (1991, p. 13).

Nas obras escritas por homens, as questões femininas, quando abordadas, como foi possível observar pela amostragem evidenciada no corpus cabo-verdiano selecionado, estas eram apresentadas mediante a ótica masculina, que não espelhava a subjetividade das experiências das mulheres, por melhor intenção que tivesse em questionar e refletir sobre a problemática de ser mulher um determinado contexto. O aprofundamento no universo do cotidiano feminino era considerado, frequentemente, sem grande valor para as Letras, por considerar-se que seus dilemas mais profundos ou corriqueiros não despertariam a atenção ao público leitor, não atingindo desta forma o sucesso editorial esperado.

Vários trabalhos literários de autoria feminina eram destruídos, ou desencorajados, ou ainda, incorporados às obras dos maridos. Algumas das estratégias empregadas pelas autoras incluem a de assumir a identidade masculina - com um pseudônimo - preferindo o anonimato.

Lembremos que também o discurso da História, sendo na sua maioria registrado por historiadores homens, ignorava sistematicamente o cotidiano da mulher e seus papéis informais, tidos como menores ou subalternos, o que gerava uma invisibilidade no campo da ação e, consequentemente, da autoria.

Convém retroceder na história apenas para sintetizar a situação da mulher que ousava ser escritora, julgando-se capaz de romper o cânone literário machista, muitas vezes estigmatizada como rebelde ou punida pela ousadia:

[...] vários poemas incluídos em The Waste Land, de T. S. Eliot, não seriam de sua autoria e sim de sua primeira esposa, Vivien Haigh Eliot, também escritora. $O$ autor do artigo afirma que Vivien havia publicado muitos dos poemas sob o pseudônimo de Fanny Marlowe, na revista Criterion, e que Eliot, 'diante da instabilidade emocional' da esposa, a havia internado em um manicômio britânico, onde ficou até falecer, em 1947 (DUARTE, 1997, p. 85). 
A luta pela emancipação literária é antiga, e muitas mulheres aristocratas assumiram a responsabilidade de se vestir de homem para ter acesso a escolas de nível superior.

Públia Hortência de Castro (1548-1595), poetisa portuguesa, travestia-se de homem para frequentar a Universidade de Lisboa. Formou-se aos 17 anos em Filosofia e costa que era profunda conhecedora de Teologia, Filosofia e Direito Canônico (Ibidem, p. 88). Segundo Constância Lima Duarte, este tipo de irreverência atingiu não somente o campo das letras, como da música e das artes plásticas, portanto a saga feminina na conquista por seu espaço social abrangeu vários segmentos artísticos, assim como o campo privado.

Estas breves estórias são representativas das dificuldades que as escritoras e artistas em geral enfrentaram nos séculos passados até às primeiras décadas do nosso século para se impor numa sociedade patriarcal que recusava aceitar a concorrência feminina, em qualquer dos seus domínios. Emily Dikinson (1830-1886), considerada "doente" por seu comportamento arredio, só foi conhecida após a morte, porque Thomas Higginson, a quem solicitou opinião acerca dos seus poemas, embora abolicionista e defensor dos direitos femininos, desaconselhou a publicação, devido ao estilo "descontrolado" e "espasmódico" (DUARTE, 1997, p. 86).

A escrita das mulheres, atenta aos pequenos detalhes do cotidiano feminino, vai pouco a pouco se organizando, buscando espaço num espaço que parecia impenetrável, o masculino, e que a qualificava como histérica (hysterion, em grego, significa útero), emocional, irracional.

Hoje, a produção literária feminina vem despertando grande interesse, por desvelar o universo do cotidiano das mulheres, antes mantido preconceituosamente como invisível ou subalterno, rasurando ou questionando o cânone literário antes dominado apenas pelo elemento masculino.

A produção literária feminina cabo-verdiana traz à tona textos cujos temas revelam as experiências sociais das mulheres de Cabo Verde, muitas vezes colocando-se como metonímia ou representante da parte pelo todo de tantas mulheres que vivem os mesmos dilemas, as mesmas paixões e desencantos. Colocando em destaque suas angústias e medos, assim como suas conquistas, a escritura de autoria feminina em Cabo Verde busca representar o cotidiano de mulheres que reinventam a historicidade do dia-a-dia, enfatizando o mundo doméstico feminino, os avanços à emancipação das mulheres, bem como as 
violências sociais e discriminações sofridas, a iniciação sexual precoce, assim como a gravidez precoce, a falta de planejamento familiar, a prostituição enfim, a problemática social que insiste em se estabelecer em Cabo Verde, a par do terreno conquistado rumo à equidade de direitos de gênero.

A história da produção literária feminina nos remete a grandes sofrimentos e descasos, tantas vezes denunciados nos textos literários de autoria masculina, seja pela indiferença dos governantes, falta de recursos, crescimento desenfreado das zonas urbanas, ou miséria em que viviam os habitantes ilhéus, sobretudo oriundos de famílias chefiadas por mulheres; só que, a partir do feminismo, os problemas são expressos em sua própria voz, que registra suas subjetividades. As mulheres caboverdianas, que por longo tempo foram colocadas à margem de denúncias apresentadas apenas na voz masculina, por até então não se poderem fazer ouvir, assumem a impotência a que eram submetidas e se organizam para o "grito".

Rosiska Darcy de Oliveira (1993, p. 109) sublinha:

A revalorização da diferença não tem por que enfraquecer a luta pela igualdade, mas deve, certamente redefini-la. [...] o projeto da diferença é pós-feminista, não porque nega ou contradiz o projeto de igualdade, mas porque corrige suas distorções.

Partindo, de forma acelerada, em busca da conquista pelo seu espaço social e literário as cabo-verdianas, no final do século vinte, impõem-se ao cânone, derrubando tabus e sendo reconhecidas pela qualidade das produções realizadas: Orlanda Amarílis (a primeira escritora reverenciada por um cânone majoritariamente masculino, como podemos observar em publicação de Michel Laban, 1992), Camila Mont-Rond (Ondina Ferreira), Dina Salústio, Fátima Bettencourt, Ivone Aída, Maria Margarida Mascarenhas, Vera Duarte, entre outras, atestam a excelência do trabalho literário das mulheres em Cabo Verde, fenômeno que se associa ao avanço acelerado da emancipação feminina nas ilhas.

Cabe ressaltar que, em entrevista a Laban (1992, vol 1, p. 263), Orlanda Amarílis ressalta, ter escrito artigos sobre a situação da mulher através das épocas no número 1 da revista Certeza (1944) e, no número 2, sobre o dia-a-dia da mulher burguesa em Cabo Verde, este censurado pelo governo colonial. O texto abrangia assuntos como "o papel secundário da mulher, ou [sobre] o seu estatuto nessa época [...] esse artigo talvez fosse uma espécie de estímulo às mulheres caboverdianas, para as espevitar" (Ibidem, p. 264). 


\subsubsection{IVONE AÍDA}

Do corpus literário de autoria feminina recortado para análise, destacaremos de início os contos "Destino dum Criol" (1990) e "Promessa" (2000), de Ivone Ainda Lopes Rodrigues Fernandes Ramos, nascida em Santa Catarina, zona rural da Ilha de Santiago, a sete de setembro de mil novecentos e vinte e seis. Colaboradora da Revista Mudjer, publicada pela Organização das Mulheres de Cabo Verde (O.M.C.V.) nos anos oitenta, publicou sua ficção Vidas Vividas, coletânea de contos, 1990, patrocinada também pela O.M.C.V. No ano 2000 publica outra coletânea, Futcera ta Cendê na Rotcha, Edições Calabedotche, de São Vicente; sua obra mais recente é A Exilada, de 2005.

Detentora, em, 1976 do $1^{\circ}$ Prêmio dos Concursos Nacionais com os poemas "llhas" e "No Comício", obteve ainda Menção Honrosa no Concurso de Natal "Terra Nova" com o poema "Vislumbre", em 1982. Utiliza o pseudônimo Clarissa Roíz em alguns de seus trabalhos.

A irmã, Orlanda Amarílis, assim classifica suas estórias: "Registros de um tempo próximo, de vidas desventuradas, de criaturas simples no estar e nos anseios" (prefácio a Vidas vividas, 1990, p. 5).

Em "Destino dum Criol", Ivone Ramos (1990, p.10) inicia o conto com um mote (estilo assumido no volume Vidas vividas), antecipando o tema que será abordado no texto: "O sonho, o mar, a luta pela vida, o fatalismo do pescador que vai à pesca e nunca mais regressa ao lar, a dor e o sofrimento..."

Ramos, nessa urdidura textual, traduz a vida simples de uma família humilde, cujo pai, Zé Catoque, ganha a vida como pescador. O cotidiano da protagonista Tanha gira em torno da família, do marido e do filho macho (depois de quatro meninas), que Zé Catoque pretende seja seu sucessor nas artes da pesca: "ganhei a sorte grande [...], 'fidjo-matcho': _ Ele haveria de ser pescador como ele, monologou" (RAMOS, 1990, p. 13).

No entanto, a premonição de Tanha ao sumiço do marido durante uma ventania repentina, já deseja para o filho um futuro diferente:

Não, Zé! Porque é que não hás-de fazer dele um outro homem, sem essa vida do mar, sem esses perigos por estas costas? Se tu

\footnotetext{
${ }^{8}$ Crioulo, habitante de Cabo Verde.
} 
soubesses como é que nós ficamos, quando vais à pesca? Enquanto não regressares, a gente anda com o coração no papo. Vida de sobressaltos, vida de tristeza, vida cansada, Zé, isso eu não quero para o Maninho! Eu sonho para ele uma vida melhor (Ibidem, p. 13-14).

Do título do conto é possível depreender que destino de pescador é o mar, mas a narrativa já se inicia propondo a presença do vento que, mais adiante, e "cada vez mais forte" (p. 14), transformará o mar em túmulo: "O vento soprava forte em rajadas. No ar papelinhos sujos esvoaçavam e a poeira das ruas batia em seco nas caras dos transeuntes" (Ibidem, p.11)

Logo o leitor poderá perceber que o destino do pescador "Criol" será trágico, adivinhado e pontuado por pistas deixadas pela esposa Tanha, que sempre associa o trabalho do marido a um mal-estar:

Um arrepio the perpassou pelo corpo magro [...] _ Estou preocupada, muito preocupada Caela. Este vento não me agrada. $\mathrm{O}$ tempo mudou, olhe o céu como está, tão feio! Tenho um mal estar, um pressentimento de algo ruim [...] Este maldito vento, meu Deus! Tenho o coração tão triste! [...] Devagar, sugava o 'canhóte'9, olhando para o crucifixo preso no ferro da cama, por um laço de fita que fora azul. Intimamente rezava:

Avé Maria, cheia da Graça - Nossa Senhora é convosco - Nossa Senhora do Socorro - Nossa Senhora do Livramento, - e de olhos fixos no crucifixo, implorava. Um pressentimento de mau agoiro pairava no ar e Tanha, malgrado seu, não podia deixar de pensar que algo havia ou estava para acontecer. [...] O gato preto da vizinha tinha saltado misteriosamente.

_ Longe vá, mau agoiro, 'ba p’onférr bitch' (Ibidem, p.17-19).

As sensações subjetivas de Tanha conduzem o leitor rumo ao final fatal de Zé Catoque: “- Oh que medo que eu tenho deste vento, Lili" (p. 14); "Um redemoinho de poeira e lixo envolveu o local. Tanha fechou a porta [...]. Um arrepio Ihe perpassou pelo corpo magro" (p. 17); "Tanha começou a tremer” (p. 19).

Suas preocupações com o mau tempo são externadas à velha Nhá Caela, que a tranquiliza. Entretanto, no mar, apesar da pesca farta e de Zé cogitar de fazer a vontade da mulher, dando outro destino ao filho Maninho, o desfecho se aproxima:

As vagas começaram a aumentar o tempo escureceu e de repente como um redemoinho, surgiu uma forte rajada. O mar encrespou-se

\footnotetext{
${ }^{9}$ Cachimbo pequeno, em língua cabo-verdiana (crioulo).
} 
ainda mais, aumentou, aumentou, parecia uma bocarra pronta a engolir, fosse o que fosse.

Os dois homens remavam com quanta força tinham; era preciso fugir à tempestade que os ameaçava. Uma tempestade misteriosa, que vinha não sabiam de onde. Molhados pelas vagas que entravam no bote, mal podiam sustentar os remos. Transidos de frio, os queixos batendo um contra o outro, tiritavam. De repente, uma onda gigantesca formou-se, subiu e em curva arqueando, caiu em cheio sobre a embarcação. A noite aproximava-se devagar, alastrando-se sobre os últimos raios do dia. [...] $O$ bote que se tinha virado, ao peso brutal da malfadada onda, não mais apareceu, nem os malogrados tripulantes (Ibidem, p. 16-19).

Tanha recorreu às rezas católicas, suplicou, mas a morte de Catoque acaba por abalar sua estrutura psicológica, demência agravada após a perda prematura, por tifo, da filha mais nova. As demais filhas "cresceram na maior miséria" e "morenas, bem parecidas”, já eram preparadas por Júlia Paxana para a prostituição (p. 24).O final irônico do conto coloca ao lado de Tanha o seu filho desaparecido, Maninho, que "cresceu ao abandono", fugiu de casa e termina seus dias em "miséria e fome", sujo, mal-cheiroso, como "pescador de lixo" à beira-mar. Ela, em seu estado alucinatório, não o reconhece:

Acariciava o costado do bote e falava baixinho com Catoque.

$\mathrm{O}$ vulto do desconhecido, com o saco às costas, passou por ela a caminho da praia.[...] Os pescadores ao vislumbrarem Tanha, ao lado dos botes, lamentaram.

Pobre mulher, pobre Catoque. [...]

E o filho? Quê do Maninho, 'moce'?

$\bar{E}$ ste, olhando para a frente, apontou com o dedo.

$O$ vulto do homem, ali despejando o seu pesado saco de lixo, ao mar, destacou-se na penumbra. [...]

Aquele não pode ser Maninho. Catoque, que Deus haja, dizia que havia de fazer dele um pescador [...]. Tanha foi sempre contra [...]. filho.

Olha, lá está ela falando ao defunto marido e nem reconhece o

Griga filosofou: _Afinal de contas, ele não foi pescador de peixe e ao fim e ao cabo tornou-se um pescador de lixo e lá está ele, sempre à beira-mar. [...] Destino dum criol, 'moces'! Destino dum criol (Ibidem, p. 25-27).

Uma passagem do conto, todavia, expande o âmbito da estória exemplar de

Tanha à ilha de São Vicente e, afinal, a Cabo Verde:

Mindelo continuava na sua rotina de sempre. O vento indo e vindo, com suas malcriações, os seus desaforos, arrastando lixo dos subúrbios para o centro da cidade. As casas também, tinham o seu 
lixo acumulado. [...] O mar espraiava suavemente, em doce murmúrio. Lá longe o Monte Cara, imponente, escondia a lua, como que envergonhada, ocultando o seu esplendor (Ibidem, p. 25-26).

O conto "Promessa" apresenta uma estrutura diversa: a protagonista, prostituta do Lombo, com determinação, vence um "destino" fechado que lhe parece reservado, expondo sua subjetividade e demonstrando sua trajetória interior em busca de ultrapassar uma situação que teimava em permanecer, condenando-a a uma condição de miséria moral ("devastadora") e material.

Bia, moça "bonita e acanhada", mas "menina de vida", habita o espaço periférico de Lombo de Trás, na ilha de São Vicente, conhecido pela vida dura de seus residentes, trabalhadores à volta do porto, e pelas casas de prostituição que servem a coreanos, japoneses, americanos, franceses e outros mais que desembarcam dos navios-escola no Porto Grande (RAMOS, 2002, p. 376). A história, contada a perspectiva da subjetividade feminina, recorre à abordagem do cotidiano mindelense, que permite o reencontro dos tempos desiguais e simultâneos no espaço do vivido e das resistências possíveis de fazer face à visão da história "miserabilista" apontada por Michelle Perrot (PERROT, 1987 apud SOIHET, 1998, p. 100), na qual se sucediam "mulheres espancadas, enganadas, humilhadas, violentadas, sub-remuneradas, abandonadas, loucas e enfermas".

O conto, a uma leitura menos profunda, sugere apenas um relato do modus vivendi de suas personagens, entrelaçando estórias de mulheres e de homens caboverdianas em situação de pobreza: as conversas nas portas das casas, os encontros ao acaso pelas ruas, os sonhos, os sofrimentos da condição humana, vivendo em um meio degradante, a vida das prostitutas, dos meninos da ponta da praia (os cicerones), estórias de emigração e de abandono.

Ivone Ramos (2002, p.375-376) desenha um retrato ficcional da realidade social dos menos favorecidos:

Lombo de Trás, morada de boa gente, mas também de meretrizes, com suas casas e quartos de aluguel, perdição, prostituição, mulheres ganhando a vida de que maneira. As casas de andar térreo, paredes esburacadas, as janelas de tábuas carcomidas, davam um ar triste ao ambiente. Ali, acolá, antevia-se a divisória dos quartos em pano barato e desbotado, às riscas, quadrinhos, ou em flores pálidas, sem vida de tanto uso, tudo no sentido de haver menos promiscuidade. A pobreza e a humildade de alguns habitantes desse bairro confrangiam o coração dos mais sensíveis. As ruas de terra batida ofereciam um panorama desagradável 
devido à lixeira acumulada e aos regatozinhos de água suja escorrendo em fios, exalando um cheiro nauseabundo.

No que toca à literatura de cunho neo-realista, a preocupação da autora ultrapassa o solo de Cabo Verde, e repercute como necessidade de expor a condição humana numa zona hostil e injusta socialmente. D' "essa gente com seus problemas cruciais de sobrevivência" (Ibidem, p. 376), conhecida como "pé descalço" (Peixeira, 2003, p.150), habitando as periferias da cidade do Mindelo, tais como Fonte Felipe, Monte Sossego, Ribeira Bote, Craca, Chã de Cemitério e Monte Lombo, fazem parte mulheres sós como Djéna, que trabalhava para o sustento dos filhos, com marido na emigração; ou meretrizes como Bia, Canda e Manuela.

Recorde-se que, no segundo capítulo, enfatizamos que, em Cabo Verde, as mulheres são as principais vítimas da pobreza, sobretudo as mulheres chefes de família, desempregadas e com baixo nível de instrução. Para contornar a falta de recursos, as estratégias mais recorrentes são a emigração (para o exterior) ou a migração para zonas urbanas, a incursão no mercado informal, dentre outras.Nos meios urbanos, o desenvolvimento da atividade informal é a saída para muitas famílias, com ênfase no trabalho feminino.

Vários são os subtemas discutidos nesse conto, dentre eles a emigração masculina, personificada por Grigol, marido de Djéna, que a abandonara com nove filhos; a violência do marido de Rosa Chica, que a espancava a cada bebedeira; o sincretismo religioso (entre o catolicismo e o espiritismo), observado nas falas de Djéna, Nuninha e Rosa Chica, apoio para suportar as vicissitudes da vida; o preconceito contra as prostitutas e a dificuldade de emprego para estas; a animalização do sexo; o sexo como mácula; o casamento como meio de enobrecimento da mulher; os serviços informais assumidos pelas mulheres para sustento das famílias.

No segundo capítulo já enfatizamos que os artigos $4^{\circ}$ e $5^{\circ}$ da CEDAW (Convenção de Eliminação de Todas as Formas de Discriminação Contra a Mulher) ressaltam a necessidade de que os Estados Partes, dos quais faz parte Cabo Verde, tomem as medidas apropriadas para modificar o padrão de comportamento social e cultural de homens e mulheres no sentido de eliminar os preconceitos e as práticas que se fundem na idéia de inferioridade de um dos sexos ou de papéis estereotipados dos homens e das mulheres; e ainda assegurar que a educação 
familiar inclua o entendimento da maternidade como uma função social e o reconhecimento da responsabilidade comum dos homens e das mulheres na educação e desenvolvimento dos filhos (Ibidem, p. 24).

No caso de Grigol, emigrado para a Holanda, "essa terra onde todos os cabo-verdianos iam em busca de uma vida melhor, labutando pelo sustento da família" (RAMOS, 2002, p. 395), depois para a Argentina, acaba por arranjar outra companheira, deixando mulher e filhos. Seu intuito primeiro era emigrar "na esperança de poder esquivar-se da vida dura de estivador e afinal a sorte não o bafejara [...], tivera a pouca sorte de ser apanhado como clandestino" (Ibidem).

Djéna (ou Eugénia), com a longa ausência do marido e as grandes dificuldades de sobrevivência da família numerosa (assume tarefas informais para supri-las, como lavagem de roupas, venda de rebuçados, carregar água à cabeça) , torna-se "mulher escaveirada", mas, honesta e positiva, ainda encontra forças para repartir seu pouco alimento com a prostituta Bia, incentivando-a a realizar o seu desejo: ter um emprego e abandonar a vida de meretriz no Lombo.

Bia, por sua vez, promete a Nossa Senhora da Luz dar a volta à igreja de joelhos se Grigol voltar a São Vicente, o que acaba por acontecer, por motivo de ele ter levado um tiro do compadre. Grigol volta sem nada, da mesma forma que partiu.

A situação da esposa, com seu abandono, torna-se trágica:

A mãe já gasta e farta dessa gritaria, num gesto de desespero dá um safanão no menino: - Cala a boca, desgraçado, onde queres que eu vá buscar comida a esta hora para te dar? Bem sabes que teu pai embarcou "diasá" para a Argentina, nunca mais se lembrou da gente, nem um tostão mandou para comprarmos um litro de milho sequer, tudo por causa daquela maldita Antoninha com quem ele vive. Desgraçado! (Ibidem, p.376).

A emigração cabo-verdiana, seja espontânea, seja forçada, nem sempre se realiza como o esperado: a inadequação ao novo ambiente, a discriminação, o emprego negado devido à desqualificação profissional, o analfabetismo (caso de Grigol) são sérios obstáculos ao sucesso.

Cabo Verde, outrora, fora responsável pelos grandes negócios das expansões marítimas, principalmente pela sua posição geográfica, servindo como porto de abrigo para reparação dos navios, descanso das tripulações e abastecimentos de víveres. O Porto Grande, em outra época (1875), trouxera para 
os ilhéus oportunidades de empregos; todavia, com a sua decadência, tais oportunidades tornaram-se cada vez mais escassas e os chefes de família partiam em busca de sucesso nas terras prometidas, na esperança de enviar remessas de dinheiro para o sustento dos que ficaram, ou também, muitas vezes, mandavam-lhes dinheiro para suas partidas.

Nas palavras de João Lopes Filho (2007, p. 21), a par das dificuldades encontradas, está,

[...] presentemente, [...] espalhada pelos quatro cantos deste planeta uma percentagem de emigrantes que atinge quase o dobro da população residente no arquipélago, numa verdadeira errância por destinos vários, consoante os impelem as diversas circunstâncias.

Mediante o abandono da família por Grigol e a luta da esposa Djéna, com dignidade, pelo sustento dos filhos (lavando roupa, carregando água), Bia a toma como exemplo e esboça seu desejo: “_ Sabes de uma coisa, Canda, eu preferia ser como a Djéna; ter um marido, filhos, uma casinha, que bom seria cuidar do que é meu, tratar dos meus filhos, ter um homem só na vida...” (RAMOS, 2002, p. 377).

A trajetória de Bia _ vinte e dois anos, "bonitona", "olhos rajados e meigos", "sorriso doce", "ar ingênuo", "rosto oval e moreno", "cabelos negros e fartos, busto bem contornado, ancas bem delineadas" _ é o fio condutor das várias estória entrelaçadas, vai da "vida fácil, que às dez, onze horas ou meia-noite sairia à socapa, lábios pintados, cabelo preso atrás por um laço garrido, em busca dos estrangeiros que passavam pelo porto e que lhe(s) pagavam bem por um momento de prazer" (Ibidem, p. 376) ao casamento com um estrangeiro:

Casamos na Mérca e hoje não sou mais a Bia rejeitada pela Dona Zinha, não! Hoje sou dona da minha casa em Betefete [...] Se vires a Canda, diz-lhe que a Bia venceu e já não é a menina do Lombo, menina de vida que ela queria que eu continuasse a ser (Ibidem, $p$. 400).

Para Bia, agora Maria de Jesus do Patrocínio ou Mississe Smith, vencer é realizar a sua maior aspiração e, com a amiga Djéna, agora vivendo co o marido, mas ainda na mais absoluta miséria, Bia complementa a sua promessa (título do conto): "Vai hoje um cheque, não me esqueci da minha promessa e podes contar sempre com ele. Não te deixarei passar falta" (Ibidem). 
No conto, fica patente o que Canda, uma das prostitutas, define como "ser mulher": "ser mulher, agradar os homens, fazer o que eles querem; por vezes são uns animais, mas pagam bem quando precisam satisfazer os seus desejos" (Ibidem, p. 377). A ótica machista que encara a mulher apenas como objeto de prazer masculino revela-se na fala de Canda, mas é refutada por Bia, seu discurso e sua conduta: "eu não me contento com esta vida triste, Canda [...]. Às vezes eu sinto vergonha, Canda, vergonha de estar vendendo meu corpo, encontrar-me com homens só por dinheiro" (Ibidem).

Lembramos que, pela Convenção de Eliminação de Todas as Formas de Discriminação Contra a Mulher (CEDAW), à qual se alinha Cabo Verde, todas as formas de tráfico de mulheres e de exploração da prostituição das mulheres são objeto do seu artigo $6^{\circ}$, enfatizando-se a premência da eliminação dessas práticas (Relatório CEDAW, p. 25).

A expressão da subjetividade feminina é uma das estratégias da literatura produzida por mulheres para desmascarar estas práticas de discriminação e subalternização das mulheres, e Ivone Aída não foge a este princípio. Revela os sentimentos de Bia (a prostituição "doía-lhe", "enojou-se de si própria", "que vergonha, que vergonha!", "amargurada", "teve repulsa por si própria”, "não cair outra vez nesse lodo", "sem emprego, escorraçada do primeiro trabalho [...] pelo preconceito dessa dama de alta roda", "haveria de vencer", "quero ser uma mulher decente").

A culpa, expressa por Bia, parece a um aspecto de vivência culposa cujas razões fundamentam-se num histórico de relações de gênero assimétricas e desiguais em detrimento do gênero feminino, que tem sido identificado simbolicamente como "sexo frágil", "segundo sexo", sombra, caos, imanência, referências simbólicas inferiorizadas em relação ao masculino, "sexo forte", "primeiro sexo", luz, ordem, transcendência etc.

À luz dessa lógica de dominação, o masculino e o feminino vêm sendo construídos através da história e neste processo, a culpa destaca-se como uma das marcas predominantes da subjetividade feminina ideologicamente manipulada.

Esse estilo dos textos de autoria feminina de registrarem os problemas e anseios das mulheres, dando-lhes voz, buscando em seu âmago os verdadeiros sentimentos, associa-se ao que Maria Odila Leite da Silva Dias chama de hermenêutica do cotidiano feminino, ou seja, a experiência vivida da historicidade 
construída pelas mulheres, que uma escrita literária de autoria feminina busca enfocar. Retomando:

Trata-se de apreender o ser através da experiência vivida, e não através de idéias, estaticamente [... . O estudo do quotidiano nas sociedades em transformação, ao resvalar por experiências de vida, escapa ao prescrito e aponta para o vir a ser, para papéis informais, para o provisório e o improvisado (DIAS, 1994, p. 375).

Na figura de Bia encontramos, de certa forma (porque o casamento ainda é uma solução redentora, problematizada, contudo, na narrativa pela fala de Canda "Casar, aturar maridos, lavar suas roupas, aturar desaforos ... Ser livre, Bia [...], sem compromissos, isso é que é bom"; RAMOS, 2002, p. 378) uma resistência a estereótipos do ideário machista (uma vez prostituta, sempre meretriz) que acompanha uma exposição de motivos sob ótica feminina.

Lembramos proposta de Joan Scott, de que o gênero indica uma construção cultural, a criação social de um ideário sobre "papéis adequados aos homens e às mulheres. Trata-se de uma forma de se referir às origens exclusivamente sociais das identidades subjetivas de homens e de mulheres" (1990, p. 5).

Neste conto de Ivone Aída são retratadas várias possibilidades e impossibilidades de vida para as mulheres cabo-verdianas sob o poder de uma ordem patriarcal que às reduz, muitas das vezes, a vários tipos de abandono.

A rebeldia de mulheres ou resistência contra esta ordem estabelecida transparece em comportamentos como o de Rosa Chica, que vê no falecimento do marido viciado em grogue e violento, sua libertação: "não se lamentou, foi até um alívio. Criticaram-na por não ter se vestido toda de preto como convinha a uma viúva, mas não ligou às bocas do mundo, tinha lá as suas razões" (RAMOS, 2002, p. 374). $E$ de mulheres que transportavam feijão e milho às cabeças e roubavam o patrão, rasgando os sacos e escoando um pouco do produto para dentro das roupas.

A narrativa, portanto, não se funda numa ótica reducionista que representa as mulheres como vítimas indefesas de uma sociedade dominada por homens, armadilha em que têm caído muitos pesquisadores ou artistas que representam a opressão e a submissão femininas.

Bia de Juninha resiste, por várias vezes, a tentações ("mãos impiedosas queriam empurrá-la para a perdição") para que se afaste de seu objetivo, voltar a ser 
Maria de Jesus: as apelações de Canda, outra prostituta, a decepção à recusa do pedido de emprego como criada na casa da esposa do engenheiro, o Dr. Ramires "comendo-a com seu olhar lascivo" e suas propostas, a "vontade de ir cair o mar", a voz de Manduca, que cantava para ela, apaixonado.

Quando convidada por Bertol, um cicerone que, o passado, Ihe levava os estrangeiros com quem se prostituía, para ser enfermeira de um estrangeiro doente que aportara, Bia resiste, pensando ser o trabalho uma armadilha. A garantia de "trabalho limpo", "remunerado" e "respeitado" a leva "a tratar dele como dama de companhia" (p. 391) e, mais tarde, emigrada, acaba por encontrá-lo ao acaso e casar-se com o antigo paciente:

A vida tinha sido dura e era bem difícil fugir ao destino que a tinha marcado. Queria lutar e vencer. Ser-Ihe-ia possível transpor essa barreira que tolhia a sua vida? Falta de trabalho, necessidade de sobrevivência (Ibidem).

A fatalidade, o destino incontornável de muitas narrativas já apresentadas o corpus selecionado, pela ótica masculina, não existe para Bia. Abençoada como Maria, e de Jesus, ela vence, com sua perseverança, a trilha que the foi "empurrada por Nhá Camila e induzida por Tanha", ao ser "desflorada por um inglês que deveria ter pago muito bem à Canda para isso" (Ibidem, p. 390), com apenas quinze anos.

A vergonha de Bia, que move a sua transformação, evoca uma outra personagem, retratada pela autoria de Baltasar Lopes no conto "A Caderneta". Mas lá, a situação da lavadeira que se prostituía por miséria não encontrava saída e o argumento serve-lhe apenas de justificativa para ao ser fichada como meretriz: de profissão: "minha necessidade que me fez receber o Noruega", diz a protagonista de Nhô Baltas.

No conto de Ivone Aída (Ibidem, p. 377), Canda lembra a situação registrada por Baltasar Lopes:

Olha antigamente, nos aos 30 a 40, ouvi dizer que davam livretes às mulheres prostitutas e todos os sábados tinham de ir ao hospital para exame médico. Mas agora isso saiu da moda. Vê lá tu, ter de ir ao hospital e ser vista pelos médicos para saberem se não tínhamos doença de mundo era uma vergonha. 
Esta intertextualidade ou dialogismo remete-nos ao fato das duas personagens não encararem a prostituição com bons olhos, isto é, a lavadeira (personagem de Baltasar Lopes) não se permitia obter a caderneta por não se assumir como prostituta, o que a discriminaria perante a comunidade, e a colocaria como concorrente do meretrício vizinho à sua casa, pois sua prática não se configurava, segundo ela, como prostituição, por ser eventual.

A personagem Bia, assumida como meretriz, atribuiu sua condição a uma armadilha, mas deseja e obtém oportunidades de emprego.

Retomando as reflexões de Esther de Figueiredo Ferraz (1952, p.2-3), Bia se esforça e age para vencer "a prostituição como forma de escravatura feminina", não permitindo que se lhe negue o direito à dignidade, muito menos aceitando a discriminação que vizinhos, mulheres casadas, moças solteiras possam lhe impor.

Em resumo, Bia "nunca desanimou, continuou lutando e tinha fé que haveria de vencer".

Venceu e (se) venceu.

\subsubsection{DINA SALÚSTIO}

Bernardina Oliveira Salústio nasceu em 1941, na ilha de Santo Antão, Cabo Verde, atualmente é considerada como uma das principais escritoras de Cabo Verde. Autora de contos infantis, como A Estrelinha Tlim Tlim; textos didáticos como Psicologia da Criança e Técnica de Redacção, ensaio como "Insularidade na Literatura Cabo-verdiana", 1998.; colaboradora nas revistas Fragmentos, PréTextos, nos jornais Tribuna, Voz di Povo e A Semana; sócia fundadora das revistas Mudjer e Ponto e Vírgula, consta ainda da antologia Mirabilis, de Veias ao Sol (1991, poesia). Sua obra ficcional abrange a coletânea de contos Mornas Eram as Noites (1994) e os romances A Louca de Serrano (1998) e As filhas do vento (2009).

Sua biografia abrange as funções de assistente social (aposentada), jornalista em Cabo Verde, Angola e Portugal, Diretora da Rádio Educativa, técnica do Ministério dos Negócios Estrangeiros e colaboradora do Instituto da Condição Feminina. 
Da sua coletânea Mornas Eram as Noites, examinaremos os contos: "Forçadamente Mulher, Forçosamente Mãe"; "Um ilegítimo desejo"; "Foram as dores que o mataram", "Tabus em saldo", "Álcool na noite" e "A oportunidade do grito".

De acordo com uma entrevista concedida à Simone Caputo Gomes na cidade da Praia, em 12 de novembro de 1994, Salústio

afirmava que denominá-la 'escritora' é exagero e complementava: 'Sou uma mulher que escreve umas coisas [...] .Escrevo poesia, mais em termos de prosa poética. (...) Faço análises sociais, mais para mim do que para publicar' (GOMES, 2008, p.218).

Em Mornas Eram as Noites encontraremos contos breves que se debruçam sobre o cotidiano feminino, seja no ambiente doméstico, seja no espaço aberto ou domínio público. Os contos de Dina Salústio colocam em voga as situações cotidianas vividas por mulheres, sem rostos ou nomes, as problemáticas que tocam às mulheres cabo-verdianas e as mulheres num panorama geral.

A temática é diversa, de violência conjugal, de afetos mal resolvidos, de atração sexual, de alcoolismo, gravidez precoce, pedofilia, enfim, Dina é uma escritora que não teme as críticas por denunciar e expor, quadro a quadro, estórias femininas presenciadas ou ouvidas, experiências vividas.

Do título escolhido para essa obra Simone Caputo Gomes (2000, p.115) esclarece:

Tradicionalmente canto de mulher, o entendimento do lugar cultural da morna o mundo caboverdiano pode derramar outras luzes sobre a significação do título: 'música eram as noites' é uma leitura para Mornas eram as noites. Música de mulheres, em que a mulher é a peça principal.

No conto "Forçadamente mulher, forçosamente mãe", o leitor faz contato com a dura realidade da personagem Paula, grávida e abandonada pelo namorado aos dezesseis anos:

Em Setembro fará calor. Para Setembro Paula terá seu filho. Ainda há dias ela ria e dançava pelos cantos. E juntava conchinhas cor de rosa na praia. E colecionava sonhos. Que é das conchinhas? Que é dos sonhos? Hoje carrega penosamente uma barriga enorme. Sozinha (SALÚSTIO, 1994, p. 35). 
O estilo inquisitivo (veja-se as interrogativas) de Dina Salústio conduz à reflexão sobre a situação das adolescentes cabo-verdianas acometidas pela constância da ocorrência da gravidez precoce, de jovens à maternidade, de jovens que, como Paula, experimentam o sofrimento de se transformarem em mães solteiras, abandonadas, sem recursos materiais, assistenciais e emocionais.

Pela ótica da autoria feminina adentramos o universo destas mães crianças que cuidarão de outras crianças e compartilhamos com elas suas dores e desamores. O que espera do futuro essa jovem? A quem recorrer, porque tão logo terá nos braços um novo ser para alimentar, mais um ser carente de meios, cuidados e afetos.

A adolescência é definida pela Organização Mundial de Saúde como a idade que vai desde os 10 anos aos 19 anos. Neste período, os primeiros desejos surgem, conhecem-se sensações nunca antes partilhadas, cometem-se loucuras sem pensar no amanhã.

O artigo cabo-verdiano intitulado "Uma problemática chamada gravidez precoce: Mal me quer, bem me quer" utiliza uma linguagem quase poética, se não se tratasse de uma realidade dura:

Chega devagarinho. Pede licença para entrar. Traz a promessa de
que veio para ficar. A primeira reacção é de querer, de imediato,
fechar a porta. Depois faz-se de convidada à força. Assim é a
gravidez precoce. Uma realidade que deixa marcas na lama e no
rosto de a quem a carrega
www.expressodasilhas.sapo.cv/noticias. 09/11/2008).

O tema da iniciação sexual prematura, que ocasiona a gravidez da jovem Paula, nos dá a dimensão, pela fala do narrador (narradora), da vivência traumática que marca a sua vida: "Aos dezasseis anos não se devia ter filhos. A natureza não soube fazer contas. Aos dezasseis anos não se devia carregar culpas. Nem vergonhas [...] E chora às escondidas. E faz contas à vida e às luas" (SALÚSTIO, 1994, p.35).

A indignação exposta no texto pela narradora em primeira pessoa incita as mulheres ao grito por seus direitos, une suas vozes contra as experiências de submissão a valores patriarcais que acabam por se tornar cruéis: 
meninas na quietude das noites. Com o seu ódio. $E$ que os desfizessem com as suas mãos de mães abandonadas. $E$ os afogassem impiedosamente nas lágrimas de todas as crianças traídas. E esfomeadas (Ibidem).

Como se pode observar, a subjetividade feminina se expressa também na fala da narradora, revelando sentimentos como revolta e ódio contra a animalização do homem que faz de crianças seu objeto de desejo e consumo.

Além dos problemas de uma gravidez indesejada para essas jovens, um outro aspecto agravante que ocorre com freqüência é o fato de elas, num primeiro momento, transferirem sua responsabilidade de mãe para as avós. Todavia, o governo de Cabo Verde tem criado casas de apoio e acolhimento às mulheres vítimas de violência doméstica e abuso sexual, para que contem com serviços de assistência psicológica, social e jurídica (cf. Plano Nacional de Acção para os Direitos Humanos e a Cidadania em Cabo Verde., 2004. p. 39).

No conto "Um ilegítimo desejo", Dina Salústio, em seu estilo indagativo, reflete sobre a vida das prostitutas, objetos do desejo masculino. Nha Djina, prostituta de esquina, "vendia-se". "E o alvará da legitimidade, deram-lho as suas necessidades" (SALÚSTIO, 1994, p. 31). Recorrendo a flashes de memória, revive os momentos amizades e amores, que simplesmente passaram por ela ou que deixaram marcas. Também as violências sofridas são narradas:

Um dia, distraída, falou do seu medo de entrar no cemitério a um cliente que, sádico, a troco de mais uns trocos, a obrigara a ir com ele até... só até à entrada. A caveira da porta arrepiou-a e, apesar do dinheiro se ter triplicado, não conseguiu coragem para 0 desempenho pretendido. Preferiu os bofetões e insultos que apanhou sem refilar. Preferiu ficar também sem a renda da casa. Pelo menos por aquela noite (Ibidem, p. 31-32).

A aproximação da velhice ("Pela esquina da Djina passavam também os corpos a caminho do cemitério. O dela, mansamente ia passando", Ibidem, p. 31) começa a preocupar a prostituta, que vive das lembranças, como a do cliente francês, que a presenteou com "um sabonete verde que cheirava a encontros suaves, palavras doces, análises ternas de urgências várias” (Ibidem).

A problemática central se circunscreve à inevitável solidão em que se encontra agora Nhá Djina, idade avançada, não possui mais atributos encantadores, não provoca mais desejos secretos. 
Utilizando-se desta nova concepção de escrita-denúncia em que a hermenêutica do cotidiano feminino e dos sentimentos das mulheres é colocada em primeiro plano, Dina Salústio retrata as violências e discriminações por que passa Djina na função de meretriz: "Na esquina, nha Djina, que foi Djina apenas, cabeça baixa, escondia seu olhar tímido de quem lhe dava uma esmola. E agora sim. Agora sim tinha vergonha porque o corpo esgotado, recusava vender fosse o que fosse em troca de coisa alguma. Até o olhar não olhava mais" (Ibidem, p. 32).

Seu "último e ilegítimo desejo”, "música a acompanhá-la ao cemitério , será cumprido, quando "a esquina acord[a] sem ela"

O sobrinho, mais pobre que os pobres, espreitou, dias e dias o cemitério, todos os enterros que se seguiram ao dela. Ao décimo dia o peixe minguado encheu de esperança: um senhor e seu violino choravam na campa de alguém. Raúl arranjou coragem e pediu-lhe, quase soluçando, que tocasse uma música para tia Djina. Uma só. Não a clássica morna hora di bai, mas uma canção francesa que falasse de amor. [...]

Djina sorriu o outro mudo e descansou para sempre, ao lado de um anjo que falava francês (Ibidem).

A sensibilidade do sobrinho, amostra das "novas masculinidades", recupera o amor e a dignidade de Djina: ao som de uma canção francesa, que relembrava os momentos de ternura que recebera do também sensível cliente estrangeiro, os anjos abençoam a velha prostituta.

Outra vitória, agora de há Djina, dignificada pelo texto de Dina Salústio.

Outro tipo de vitimização das mulheres, a par do sadismo, é apresentada no conto "Foram as dores que o mataram": a violência doméstica.

Já referimos em capítulo anterior que as causas mais prováveis apontadas para a violência doméstica em Cabo Verde são: a condição sócio-econômica e o machismo ou sentimento de superioridade do homem sobre a mulher, especialmente nas classes menos favorecidas economicamente; o alcoolismo, o consumo de drogas, o desemprego (CEDAW, p. 71).

Atualmente, depois de do estabelecimento de legislação competente, muito se tem conquistado, todavia a violência ainda destrói a harmonia dos lares, geralmente partindo do homem a agressão à companheira. O fator econômico é a priori a causa mais freqüente, seguindo-se do alcoolismo.

O narrador (ou a narradora), no início do texto, em visão colada à da personagem principal, relata a amargura da mulher obstinada a em negar ser a 
agente do assassinato do marido. O discurso não é datado, parecendo querer documentar um fato que se prolonga na sociedade cabo-verdiana:

Não importa o dia. Nem importa mesmo o ano em que se conheceram. E houve um momento em que se amaram. Talvez tenha havido muitos momentos em que se amaram.

Depois a rotina de vidas que se afastaram e, incompreensivelmente, continuaram juntas. E, dramaticamente caminharam juntas, num desafio permanente à vida, à morte, ao direito de viver (SALÚSTIO, 1994, p.17).

Eurídice Furtado Monteiro (2009, p. 101) ressalta em Mulheres, democracia e desafios pós-coloniais, que, em Cabo Verde:

$\mathrm{Na}$ família, embora o papel das mulheres se tenha valorizado grandemente, ainda são relativamente comuns às práticas de violência doméstica [...] , que passam pela agressão física, pela agressão psicológica, por uma carga horária mais sobrecarregada para as mulheres.

Salústio, ao recriar a situação de violência física e psicológica contra a mulher, fá-la na perspectiva desta como vítima, eximido-se de culpa por matar o marido e transferindo esta para as pancadas e as torturas infringidas por aquele:

Não matei o meu marido.

Eu amava-o. Porquê matá-lo?

Foram as dores do meu corpo que o condenaram. Foram o sangue pisado, o ventre moído, as feridas em pus.

Foram as pancadas de ontem, as de hoje e, sobretudo, as pancadas de amanhã que o mataram.

Eu amava-o. Porquê matá-lo?

Foi o meu corpo recusado e dorido após o uso e os abusos. Foram a tristeza, o desespero e a dor do amor que não tinha troco (SALÚSTIO, 1994, p. 17, grifos nossos).

E sintetiza, numa perspectiva inusitada, fazendo do marido o seu próprio algoz: "Ele matou-se. Criou um espaço onde coabitavam a violência, a destruição, a miséria, o animalesco. E nós. Deu-me armas e fez-me assassina" (Ibidem, p. 18).

Conforme mencionado anteriormente, boa parte das agressões sofridas por mulheres é calada, silenciada entre as quatro paredes, por mais testemunhas que haja, por medo das represálias. 
No caso desta personagem, Dina Salústio opta por criá-la como anônima, para simbolizar tantas outras mulheres cabo-verdianas abusadas, reprimidas e violentadas. Esta personagem, no entanto, radicaliza sua revolta, sobretudo, pela falta de esperança. Matar o marido não é solução para suas mágoas e tristezas, mas um ato de desespero de uma mulher "frágil" (p. 18), ocasionado pela violência e pelo desamor.

O conto "Tabus em Saldo" revela outro tipo de violência, a cometida contra crianças e aos adolescentes: o abandono, a exploração sexual, a pedofilia instigada pela mídia globalizada (cinema e televisão), a hipocrisia social.

Logo de início, a narrativa expõe estereótipos do universo patriarcal, como: "Se tivesse nascido macho era um rapaz, mas como nasceu fêmea é mulher. As fêmeas são sempre mulheres" (Ibidem, p. 48).

A estratégia da autora é descer

[...] aos esconderijos privados desta sociedade que, dolorosamente ou não, recorre a proibições, enfatiza princípios, agrupa-os em tabus para defesa mínima de um certo decoro, ou, dando uma de evoluídas, parcelas outras há, que embandeiradas da necessidade de se cortar de vez com a hipocrisia social, em nome do progresso e outros mais, arranham a ferida onde ela dói mais: as crianças e os adolescentes (Ibidem)

A denúncia refere-se à transformação "em objectos de gozo mais sofisticado, em produtos rentáveis" (Ibidem) dos menores cabo-verdianos, “juventude bonita" que é exposta "aos instintos curiosos", ao voyeurismo: "O negócio rende. Cada espiadela, vinte escudos [...]: o custo de uma espreitadela ao clandestino filmado de nossas crianças fêmeas" (Ibidem).

A narradora, assumido explicitamente a perspectiva e a subjetividade destas crianças fêmeas, denomina os fotógrafos que incitam a pedofilia e a exposição de meninas de "caçadores de corpos" (Ibidem, p. 49), seja de "meninas européias", de "orientais" ou das "americanas do sul e do norte" (p. 48).

E vai mais além, na sua contundente revolta: “...À noite, na televisão, passou um filme sobre prostituição infantil, em várias nuances. Eram crianças americanas. Podiam ser caboverdianas" (Ibidem).

A violência, como se pode observar, expande-se em âmbito global, é avalizada pela própria sociedade capitalista. 
Mornas eram as noites, em suma, ataca com energia a violência machista expressa em vários níveis: de superioridade de gênero, psicológica, física, econômica, expressa no incremento à prostituição feminina (adulta e infantil), na pedofilia, na irresponsabilidade paterna quanto à maternidade precoce e suas conseqüências (aborto, filhos sem pai, prole muito numerosa), o voyeurismo.

Dina Salústio, em entrevista concedida a Simone Caputo Gomes (2000, p. 114), sintetiza: "Em Cabo Verde, quando nasce uma menina, ela já é uma mulher". Contraposta à frase célebre de Simone de Beauvoir (1949), "Não se nasce mulher, torna-se", a de Dina propõe uma espécie de estigma que marca as meninas caboverdianas logo ao nascimento, ou seja, o legado pesado que já carrega, a discriminação social, a quantidade de obstáculos à sua realização plena.

"Álcool na Noite", mais um dos breves contos de Dina Salústio, ao pintar mais um quadro feminino do cotidiano cabo-verdiano, enfoca Santo Antão como ilha de preferência. Em entrevista a Simone Caputo Gomes (2008, p. 227), em novembro de 1994, Dina Salústio ressalta, sobre sua ilha natal:

Sou de Santo Antão. Vais encontrar em todos os contos Santo Antão. [...] É que a ilha está em mim. [...] É como se todas as ilhas de Cabo Verde fossem Santo Antão. [...] É uma ilha muito poderosa, possessiva. É a ilha a que vou quando preciso encontrar alguma coisa

A narrativa traz à baila a embriaguês de duas mulheres numa noite calma e quente; a figura feminina se mostra em situação degradante, quase animalesca. A narradora-personagem, a princípio, se assusta com os grunhidos vindos da direção do cemitério:

De lá das bandas do cemitério uma voz canta uma morna. Tudo normal se a voz não parecesse sair dos intestinos de algum bicho em vez de uma garganta humana, por muito desafinada que fosse. Era de uma mulher, reconheci com mais cuidado. Aliás, eram as vozes de duas mulheres. A segunda faz coro com obscenidades e a desarmonia, o desleixo transparecido e o despudor agridem os ouvidos (SALÚSTIO, 1994, p.46).

A partir do estado de degradação o qual se encontram as duas mulheres, a personagem narradora expressa sua subjetividade, sua empatia com a situação das jovens: 
Há um sentimento incomparável nas palavras quotidianas. Vêm-se aproximando. E estão bêbadas. Depois um palavrão. Talvez o eco de uma topada. E outro. E gargalhadas. Não consegui entender a felicidade dos risos debochados. [...] Sinto raiva (Ibidem).

Mulher como as outras, a narradora demonstra sua indignação com a condição grotesca que estas mulheres apresentam, a cena a "fere" (Ibidem).

Num crescendo de tragicidade, uma das mulheres é abordada por uma criança, a filha, que é imediatamente insultada pela mãe, seguindo-a na noite.

Fechando a sequência de cenas, cortadas cinematograficamente, conclui a narradora, negando este tipo de vivência para gerações de mulheres:

A noite não tinha mais magia. Acho que nem estrelas. Apenas uma ferida no sentimento antigo de ver nas mulheres, para além de tudo, seres diferentes. [...] porque esta incompreensão para sua embriaguês? Porque o preconceito contra fraquezas que não são minhas?

Colocando-se o lugar das companheiras de gênero, esta narradora em primeira pessoa toma para si a responsabilidade de compreendê-las, ao mesmo tempo em que expõe "vergonha, humilhação e revolta. E pena (Ibidem, p. 47).

Como é possível depreender, a escritura de autoria feminina, sobretudo a produzida por Dina Salústio, toma posições frente às situações apresentadas na narrativa, revela a subjetividade feminina e as aprendizagens possíveis a partir de circunstâncias que envolvem as experiências das mulheres.

Simone Caputo Gomes, na terceira parte de seu livro Cabo Verde Literatura em Chão de Cultura (2008, p. 220), dedicada à escritura feminina, ressalta a importância do trabalho literário de Dina Salústio:

A reivindicação, o lirismo e o humor mesclam-se nas narrativas, produzindo um efeito poderoso do discurso: o de comunicação. Daniel Spínola sublinha que Dina Salústio 'inaugura uma nova forma de comunicar e um novo modo de percepção do mundo' na ficção cabo-verdiana. Em Mornas eram as noites, um discorrer de situações surpreendentes, de sensações, de informações, de acontecimentos imprevistos envolve o leitor, levando-o a um enfoque diferente para situações sociais e existenciais cristalizadas ou estagnadas. 
De acordo com Gomes, também o leitor aprende uma nova forma de encarar o universo feminino cabo-verdiano ao ler os contos salustianos.

E as mulheres cabo-verdianas, um processo de possível conscientização, já se permitem ter voz, ação, vencer barreiras, de qualquer natureza e tamanho. 0 conto "A oportunidade do grito" nos leva a tal raciocínio:

Nele, uma mulher não nomeada, mas qualificada pela narradorapersonagem como "vencedora", dialoga com outra, Elsa, marcada pela "ansiedade" e pela "fragilidade" (SALÚSTIO, 1994, p. 7). A narradora assim descreve a vencedora: "força inquieta que lhe escapa dos olhos", "capacidade de derrubar tudo que seja obstáculo ao que deseja" (Ibidem). Pedagogicamente, o texto, a vencedora vai, aos poucos, dando a sua receita de sucesso, aconselhado Elsa: "Tens de [...] pôr de lado o marasmo que te envolve", "arranja força, sacode o mau olhado ou seja que diabo for, mas vive", "tens que incomodar, mostrar que existes, perturbar, brigar com o mundo e contigo. Sobretudo contigo", 'tens que dar umas trochadas, rapariga' (Ibidem, p. 7-8).

A coragem de "desafiar-se a si mesma", segundo a personagem vencedora, angaria respeito.

Por fim, a vencedora propõe que a amiga discuta até com Deus: "Mostra-lhe suas razões. Grita se for preciso [...]. Enfrenta-O. Deus gosta de mulheres fortes" (Ibidem, grifos nossos).

A narradora conclui que "uma mulher vencedora" é aquela que enfrenta "com garra todas as situações", até mesmo Deus. E sua percepção subjetiva "goza o prazer da descoberta".

O leitor, como podemos perceber, é continuamente alertado e pedagogicamente esclarecido sobre a situação das mulheres em Cabo Verde (e no resto do mundo) e os contos, ao mesmo tempo, expõem a subjetividade das mulheres, sejam personagens ou narradoras, revelando, por sua própria voz e pelo seu íntimo, o universo feminino.

\subsubsection{MARIA MARGARIDA MASCARENHAS (M.M.M.)}

... Levedando a Ilha (1988) é uma coletânea de contos de Maria Margarida Mascarenhas natural da cidade do Mindelo, ilha de São Vicente, , onde nasceu em 
1938. Fez os seus estudos na escola do Liceu Gil Eanes, naquela cidade e é formada em Turismo e Línguas

Reside em Oeiras, Portugal. Foi colaboradora da folha literária Sèló - página dos novíssimos, organizada por Rolando Vera-Cruz Martins, Jorge Miranda Alfama e Oswaldo Osório, na qual colaboraram, além dos organizadores, também Arménio Vieira e Mário Fonseca.

Participou da fundação da revista Presença Crioula (1972-1974), editada pela Associação de Caboverdianos de Lisboa, e foi a sua primeira diretora. Colaborou também no boletim Cabo Verde, no jornal Notícias de Cabo Verde, nas revistas África e Raízes. No volume mencionado reúnem-se alguns dos seus melhores contos, uns dispersos e outros inéditos, dando assim a conhecer a um público mais vasto uma contista cabo-verdiana que se iniciou nas lides literárias em 1961, quando ainda estudante do liceu.

Dentre ele, selecionamos dois: "Toia" e "Vigília". Muito embora esta escritora seja praticamente desconhecida entre os brasileiros, parece-nos importante destacar seu engajamento nas causas sociais, mereceu destaque pela abertura à reflexão sobre causas femininas.

Em "Toia", o conto nos remete à estória de "outras tantas Toias", caboverdianas ou não. Àquelas cujas insatisfações são expostas, "com raiva" e "em forma de GRITO" (como o faz a mulher vencedora do conto de Dina Salústio) por um narrador, que acrescenta:

Sempre pensei em escrever a tua história, TOIA, [...], num desses dias em que a tensão das frustrações, das pressões e dos recalcamentos se liberta plenamente, rompendo todos os moldes, derrubando todas as barreiras, possibilitando toda a ascensão desejada (MASCARENHAS, 2002, p. 544).

Como é fácil constatar, a narrativa se inicia com a empatia dos sentimentos do narrador com os de Toia, num GRITO que aquele gostaria que "repercutisse para além do infinito e que encontrasse eco em cada ser universal" (Ibidem).

A pedagogia do narrador é explícita: _ "Queria então que desse grito algo germinasse, crescesse, florisse e frutificasse" (lbidem) _, assim como seu envolvimento: o eco do grito tem por função deter "a torrente que nos sorve e nos arrasta para tudo o que não idealizamos mas consentimos" (Ibidem, grifo nossos). A adoção da primeira pessoa do plural irmana o narrador (a?) a Antónia do 
Nascimento (Toia) e a 'todas as 'Toias-mulheres' e todas as Toias-situaçãocondição' ", analfabeta, emigrada, com filhos de vários homens, prostituída, abandonada na diáspora.

Em Toia se resumem situações vividas por várias mulheres, nela representadas. Mas com sua própria voz, embora ecoando dentro de consentimentos que the obstruem os caminhos.

Ao opor-se à retórica do silêncio, o grito, que propriamente não sai da garganta de Toia, mas insiste na vontade apresentada pelo narrador como se houvesse entre ambos uma simbiose, leva a uma proposta de denúncia na exposição de quadros revoltados como os de "mil crianças truncadas e mil moças exploradas..." (lbidem, p. 546).

A descrição física de Toia retrata-a com "VINTE ANOS. Duas rugazinhas esboçadas em cada canto dos olhos" (p. 544), madona de "seio pequeno e túrgido" a amamentar o seu menino, a "pele cor-de-mel". Bela, esguia, porém "viola tangida abandonada", "melodia interrompida" (Ibidem).

Como se quisesse descoisificá-la, o narrador a apresenta como Antónia do Nascimento, que tem "que conquistar a dimensão humana" a que tem direito, superando a circunstância de estar excluída pelo sistema, como iletrada, pobre, desempregada, sozinha com o filho sem pai (um "impecilho", de apenas dois anos de idade, que lhe tolhe o desempenho profissional, pois ganha 500 escudos e não tem com quem deixar a criança) em Lisboa.

$\mathrm{Na}$ ilha, Toia, precocemente mãe ("Tiveste um menino tu menina também" (lbidem, p. 545), deixou o outro filho ("ôte fidge", p. 545), tido aos dezesseis anos, delegado à avó para cuidados e educação.

O texto, de autoria feminina, elaborado por uma escritora jovem em fins da década de 80 , denuncia a alienação persistente na qual as mulheres ainda se deixam envolver, obstruindo a possibilidade de mudança desse quadro lastimável. Viúva de português morto no mar, Toia sequer reivindica os direitos que tem o seu filho, fruto desse amor.

O conto "Vigília", premiado em 1961, tem por mote, segundo Ondina Ferreira, organizadora da coletânea Elas contam... (2007, p. 79):

Paula é uma personagem simbolizadora de um tipo de mulher caboverdiana pobre e iletrada, que, amigando-se com vários homens [...], vê a vida escoar-se-Ihe mesquinha. Cheia de filhos de 
progenitor diverso, carrega o enorme sofrimento de uma vida desgraçada. Mas ela urde um plano com 'sabor vingativo'...

Paula, protagonista do conto, metaforicamente, traduz a situação de várias mulheres cabo-verdianas, cuja vida cotidiana é fundamentada na ordem matrimonial. Para a obtenção dos seus objetivos, possuir casa, filhos e marido, persiste em buscar uma falsa segurança até as últimas conseqüências.

Detentora de condições financeiras e intelectuais reduzidas, com quatro filhos de pais diferentes, Paula insiste em contornar situações que enfraquecem e humilham

A personagem vive seu cotidiano miseravelmente e, em flashes de memória, relembra o seu passado e reflete sobre o presente, reavaliando as brigas violentas com o atual companheiro, que chega sempre, às noites, alcoolizado e enfurecido, desculpando-se no dia seguinte e atribuindo a culpa ao grogue.

A escritora enfatiza a juventude de Paula, seu desenvolvimento físico prematuro, as diversas oportunidades que tivera, nos bailes, de se envolver afetivamente, suas escolhas equivocadas:

Mal desabrochara. Mas as formas prometiam. Rodopiava sem parar em quase todos os bailes dos bairros. Já tinha a sua fila de pretendentes que nada ainda tinham conseguido. O mais persistente e que ela não via com desagrado era o Toi. Mas não, não cairia. Ele vivia com Nuna e tinham três filhos. Não. [...] Mas houve aquele piquenique... Toi conseguiu 0 que há muito desejava (MASCARENHAS, 2007, p. 80).

Paula entrega-se a Toi, que a tira de casa. A pedofilia explicitamente denunciada ("Ela era menina!", p. 80) alia-se a contos de outras autoras já examinados em nosso corpus, demonstrando a frequência com que homens mais velhos exploram a imaturidade feminina em Cabo Verde.

A personagem Toi, experiente e pai de família, ilude Paula com promessas que não cumprirá:

No dia seguinte tirara-a de casa. Estava orgulhoso dela. Ela era menina! Falou-Ihe em casamento. Começara mesmo a tratar dos papéis. Ainda não acabara definitivamente com a Nuna e conservava em casa dela as suas roupas apesar do escândalo que aquela armara. Mas prometia... De repente notou que ele já não falava em casamento (Ibidem). 
A magia, na ótica popular da personagem protagonista, é o motivo para que Toi não abandone a esposa: "Foi então que a Bia lhe veio contar que a Nuna fizera 'corda' para Toi não casar com ela. Está claro: as roupas do Toi que continuavam em casa dela. [...] O Toi estava 'amarrado'” (Ibidem).

O feitiço africano é um dos aspectos tradicionais do cotidiano feminino e da comunidade, em especial no que concerne a Cabo Verde. A consonância do cotidiano feminino com a religiosidade é assim acentuada por Simone Caputo Gomes (2008, p.162):

O encontro da religião católica com as práticas africanas mantém-se ainda por via feminina, que conservou os costumes do batizado, da boda o culto do padrinho e da madrinha, ao lado das superstições e práticas mágicas, dos recursos às 'botadeiras de sorte'.

Para a ingenuidade de Paula, o feitiço justifica a falta de caráter do macho

Terminado o casamento, outro aspecto relevante se destaca: as filhas ficarem sob a guarda da avó paterna, morando juntamente com o pai, numa espécie de "djunta-mon" 10 (G.N.), fato comum em Cabo Verde.

Entretanto, Paula "atingira a plenitude das suas formas, e muitos ainda a desejavam" (Ibidem). Decide então, para fazer "desaforo" ao Toi, porque eles "não se davam" , ir viver com Manoel, gerando mais um filho. "Não viveram muito tempo juntos" (Ibidem, p. 81).

Infeliz na vida amorosa, Paula opta por dar uma pausa nos relacionamentos. Mas não tem firmeza na sua decisão:

Depois do Manoel resolvera não ter mais homens. Para quê? Só davam aborrecimentos. Passou mal quando teve o filho do Manoel. Rasgaram-lhe o peito.

Mas a vida decorria menos mal. Tinha seu negócio. Todos os dias subia à cidade com seu tabuleiro de venda. Apareceu este então. $\mathrm{O}$ Armando (Ibidem).

Outro homem passara por sua vida, desta vez a personagem escolhe um homem mais novo, Armando, "demasiado novo", "um garoto", segundo ela, "bruto", "um animal" (p. 81).

\footnotetext{
${ }^{10}$ CARREIRA, António, 1984, p.157: Djunta-mon é um termo utilizado antigamente pelo povo rural, tem seu significado de entre-ajuda, um ajudar o outro nos trabalhos da lavoura. No texto foi utilizado o termo com o sentido de ajuda entre os parentes (avó e pai).
} 
Ciumento, Armando arma um escândalo um baile de Carnaval, Levando Paula "para casa à força de pancada e brutalidade" (Ibidem). Os sentimentos femininos são "vergonha" e "raiva" e o motivo exposto pelo homem, bebida.

Xingamentos ("porca!", "sua...") e "insultos" (ibidem, p. 82) acompanham o tratamento preconceituoso, desigual (os dois estavam o baile, por concordância mútua e somente a mulher é penalizada) e o espancamento na presença dos filhos, que obriga Paula a tratamento prolongado em hospital e incute nas crianças as imagens do abuso.

Ressalte-se que, neste conto:

As crianças vivem em um ambiente em que são comuns as brigas entre homens e mulheres, as lutas da mãe com o pai ou parceiros, enfim, vivem em um meio onde a agressão física é um comportamento vigente. O filho aprende desde cedo que uma forma, e das mais importantes, para sobreviver e alcançar prestígio é impor-se pela força. Mesmo a mulher, ao observar cotidianamente o comportamento social de sua mãe, e das outras mulheres, vê tal tipo de conduta como modelo a ser seguido (BACELAR, 1982, p. 123).

A partir desse contexto violento, a resistência de Paula se dará por meio do silêncio, uma forma de contradiscurso: "Continuavam juntos mas nem pio. Preparava-lhe as refeições e deixava-as sobre a mesa. Ele se quisesse que comesse" (Ibidem) e dos preparativos da vingança: "Estava só à espera de arrumar umas contas. Mudaria com o que Ihe pertencia" (Ibidem).

O final do conto reitera os planos de Paula, apesar do arrependimento confesso do companheiro. Ela vende rebuçados (balas, doces) e arquiteta o abandono do algoz: "As moedas caíam na bandeja... Não, aquilo não ficaria assim. Contou o dinheiro... Era só esperar que ela arrumasse as suas contas!..."

Em carta ao Editor, autorizando a publicação de seus contos, Maria Margarida Mascarenhas ressalta: "A condição feminina em Cabo Verde foi e continua a ser um factor de indignação para mim" (Apud FERREIRA, Ondina. Elas contam, 2007, p. 62).

Podemos perceber, a partir desta afirmação e do final do conto "Vigília", que, quando elas contam ou escrevem, ou seja, quando se representam (autorepresentam), a indignação com as experiências de violência e subalternidade vividas pelas mulheres contamina os textos, expressando subjetividades femininas (mulheres vencedoras, rebeldes, vingativas, assassinas, mulheres que gritam) que 
extrapolam os limites da visão miserabilista que as reduzia a vítimas passivas do macho.

\subsubsection{CAMILA MONT- ROND (ONDINA FERREIRA)}

Ondina Maria Fonseca Rodrigues Ferreira, que utiliza o pseudônimo Camila Mont-Rond, nasceu a bordo do navio português Guiné em viagem de Mindelo para Lisboa, em 17 de agosto de 1946. Licenciada em Filologia Românica pela Universidade de Lisboa, é Mestre em Ciências de Educação pela Universidade de Massachusetts.

Foi membro do Governo (1991-1996), Deputada da Nação e $1^{\text {a }}$ vicepresidente da Assembléia Nacional (1996-2001). Colaboradora e co-fundadora de revistas e boletins de ensaio e crítica literário-cultural caboverdianos. Destacou-se entre co-fundadora e colaboradora da Voz di Letra; Fragmentos; Pré-textos; Magma; Cultura da qual foi diretora; Arquipélago; Artiletra; Farol; Revista África de Literatura e Arte e Cultura. De igual importância foi colaboradora de artigos de opinião nos jornais Terra Nova e Expresso das Ilhas. Publicou um romance, Amor na ilha e outras paragens (2001) e organizou um volume de contos femininos, Elas contam... (2007), do qual extraímos o texto "O Suicídio de Quina", que assina como Camila Mont-Rond In: Ondina Ferreira, faz parte de um projeto iniciado em 2004 por 12 escritoras caboverdianas que falam da vivencia do arquipélago.

No início da narrativa, observamos o uso de recurso semelhante ao utilizado por Mascarenhas (M.M.M.), ao recorrer a um mote que prepara o leitor para o assunto a ser abordado:

O mito da virgindade feminina, a ignorância, os preconceitos e a violência do meio, levaram a jovem Quina ao desespero. O suicídio foi a saída e a forma de 'lavar a vergonha' da família... (FERREIRA ou MONT-ROND, 2007, p. 219).

O texto tem início com o diálogo da narradora-personagem com um possível interlocutor, descrevendo seus sentimentos em relação ao suicídio da amiga de longos anos.

Diferentemente da dominância o aspecto físico nas descrições de mulheres por escritores masculinos, a escrita literária de autoria feminina, exemplificada aqui 
por Camila Mont-Rond (Ondina Ferreira) apresenta por suas características intelectuais. Num flash back, a narradora retorna aos bancos escolares para tentar compreender o que levara uma pessoa brilhante a tal ato de desespero:

Admirava a facilidade com que ela resolvia as frações, os números decimais, nas aulas de aritmética e geometria da $D$. Ana de Castro Azevedo. Nas provas eu piscava-lhe o olho para me passar os problemas que ela, sabia eu, já tinha resolvido (lbidem).

Todavia, estacando seus estudos na quarta classe, Quina prepara-se para o casamento com dezessete anos, com rapaz de idade semelhante.

A alegria de Quina, contudo, durará apenas as cerimônias do ato do casamento: na lua-de-mel, o marido acusa-a de não ser mais virgem, ignorando o fato de que o caso da esposa era raro, "de não existência de hímen”, como afirmará depois o médico, Dr. Furtado (que realmente ajuda a furtar o sucesso do casamento de Quina).

A partir deste fato, o conto apresentará inúmeros estereótipos e chavões paternalistas que pretende denunciar, pela ótica feminina. Adiante os esclareceremos.

O primeiro deles a posição da comunidade, sobretudo dos representantes machos dela, a favor de Timas e de reprovação a Quina:

As opiniões eram largamente apoiantes das atitudes do Timas e das censuras das tias. Minhas irmãs e eu guardávamos para nós, cheias de temor, a solidariedade que ia inteira para a pobre Quina. Não a podíamos demonstrar. Ousei à mesa _ estribada na crença de que à mais nova tudo era permitido _ manifestar a minha posição achando estúpida a acusação do noivo. Quase que ia levando uma sova do nosso pai. Que tivesse decência. Se aquilo se admitia numa menina bem-educada! Defender poucas-vergonhas! (Ibidem, p. 220).

Acusada injustamente e vítima de preconceitos vários porque "fora para o casamento já desonrada" (p. 221), Quina é devolvida pelo marido à família ("Retornasse de onde viera!", vocifera aquele, p. 222), e recusada pelas tias, que a aconselham a matar-se, "para lavar a sua honra" (p. 223) e a da família:

Delas apenas ouvira ralhos e palavras desencorajadoras. Que se cuidasse antes. Que nada já podiam fazer por ela. Azedas e rudes diziam da vergonha que sentiam por terem perdido tempo a criar 
uma desgraçada como ela! Que o melhor que ela tinha a fazer para lavar a sua vergonha era matar-se (Ibidem).

Lavar a honra com a morte faz parte da cultura tradicional cabo-verdiana em algumas ilhas, em algum momento da história do arquipélago. Tal preceito, ainda hoje convertido em discurso, persiste na mentalidade machista em relação à mulher, delegando a ela o fardo da perfeição e da pureza, e faz parte do mito do patriarcado machista e de sua ordem, que teimam em punir a autonomia feminina relacionada aos tabus da sexualidade.

Segundo João Lopes Filho (1996, p.152), "o conceito de honra, o sentido da virtude, est[á] especialmente associado à mulher, tendo uma conotação religiosa e sexual e portanto diferente do tipo de honra [...] intimamente associada aos valores masculinos".

Ignorado e, portanto invisível o corpo humano feminino na sua complexidade, por parte da comunidade, e em especial pelo elemento masculino, resta-Ihe, neste conto, o apagamento ou o suicídio de Quina,sob protesto veemente da narradora personagem que passa a vestir-se de escuro ou negro, como forma de resistência: "Foi a forma que eu encontrei pra pôr luto à minha amiga" (p. 221).

Outro tema evocado é o matrimônio precoce contraído pelas jovens com estrangeiros bem mais velhos, como preventivo de gravidez. A crítica a este tipo de dispositivo social também é alvo da narradora. Observemos a fala preconceituosa de uma das personagens femininas (a mãe da personagem-narradora):

Mas isso é natural. Olhe é sempre mais seguro do que andar por aí
e um dia destes aparecer às tias de 'barriga'. Por outro lado, ela e o
noivo são da mesma geração. Não é como se vê por aí essas
moças a casarem com americanos velhotes que regressam à terra
alquebrados apenas para assegurarem a pensão e morrer. E
escolhem logo as moças novas que mais parecem filhas ou netas
(lbidem, p. 220).

No conto de autoria masculina intitulado "Beira do Cais", de Teobaldo Virgínio percebemos semelhante preocupação com os fatores honra e vergonha pelo fato de o homem cabo-verdiano ainda persistir na conservação de determinados tabus.

Das personagens em questão, Quina ("O Suicídio de Quina") se opõe a Xanda ("Beira do Cais"), de certa forma, segundo os ângulos de visão recortados por 
Camila Mont-Rond e Teobaldo Virgínio: a primeira é condenada a humilhação sem precedência, vítima de escândalo e "desonra" familiar por ato que não cometeu; quanto à segunda, Xanda, por sua vez fora vitima da desonra, porém a ressalva de ter sido considerada "desonesta" para com o marido, porque não era mais "pura", o que demonstra uma empatia do narrador (e da visão autoral) com o marido traído. Xanda é culpada, portanto, dentro de uma ótica masculina dentro e fora do conto; Quina é veementemente defendida pela personagem-narradora e pela estrutura de autoria feminina do texto, que trata o desfecho do caso como uma possibilidade de "acalmar o julgamento negativo das pessoas" (p. 225), consideradas "insensíveis" ao drama da personagem protagonista e imersas numa profunda ignorância: "Só que ninguém mais ouviu a declaração do médico. Também nem ele a divulgou ao povoado. Nem iriam entender o que significava ter ou não ter hímen" (p. 225).

Como esperado pela condução da trama, o destino de Quina é ser o cordeiro imolado pela ignorância da família e da comunidade, e sem direito a luto:

Afinal, em quê isso importava? O desfecho do caso, não fugiu ao que devia ser. Quina, a conselho das tias, 'lavou a vergonha delas e a do Timas'. Enfim, não havia outro remédio. Teria de ser assim. $\mathrm{O}$ destino e a honra equilibraram-se. Acalmou-se o julgamento negativo das pessoas. Quando assim sucedia nem luto se punha à jovem morta (Ibidem. p.225).

Há várias passagens no texto que nos dão pistas sobre a carga de reflexão que Ondina Ferreira (Camila Mont-Rond) quer imprimir à trama. Os rituais caboverdianos das bodas, suas festas e preceitos, são abordados para enfatizar a importância da virgindade de Quina para o povoado em que vivia:

A véspera do casamento havia sido comemorada alegremente. Ela e Timas ocuparam, como mandavam as regras, os respectivos tronos [...] conselhos jocosos sobre o que deveria ser 0 comportamento do macho na noite de núpcias, seguido de outros conselhos para a vida de casado em que ao homem era dito quer 0 lugar dele não era a casa. Isto pertencia à mulher.[...]

Quina havia chorado mais do que se pedia a uma noiva séria e emocionada no dia do casamento. Até parecia que da parte dela houvera algum pressentimento do que the reservado para o dia seguinte. [...]

Agora a realidade era outra:

- 'De que antes dele, ela conhecera outro homem; de que já a não queria; que retornasse de onde viera. Que de uma coisa estava ele 
certo, ela já não era virgem! Pelo menos ele não a achara como deveria ser!'_Assim gritava Timas.

"Retornasse de onde viera!" _ repetia sem querer ouvir argumento algum (Ibidem, p.222).

"A mulher no lar e o marido fora de casa" era o mote repetido pela comunidade para prefigurar "o futuro do casal" (p. 221). A virgindade, a nosso ver, simbolizaria a redução das mulheres à exclusividade do domínio do privado, cabendo a ela preservar a honra do lar. Ao homem, nenhuma exigência era feita, porque dele seria o domínio público, na ótica que o conto pretende denunciar.

Para Maria Lúcia Rocha-Coutinho (1994, p. 16), os construtos binários baseados na diferença biológica (que aqui se torna pauta para definir honra e pureza com base na virgindade de Maria, que chegou a conceber "sem pecado") podem ter criado, ao longo do tempo, uma divisão bastante resistente à mudança, a de público e privado como respectivos espaços do masculino e do feminino.

Enfim, a tragédia poderia ter sido evitada, a inocência de Quina comprovada, não haveria desonra se o silêncio não permanecesse na boca das autoridades maiores, representantes saúde, da ordem e da justiça. Quina, no seu ato de morte, como se reprovasse a cegueira dos seus compatriotas e aludindo, talvez, à cegueira da justiça, opta por cobrir o rosto: "Alçou o topo da serra. Com o xaile que levara fez uma venda à volta dos olhos e abeirou-se do precipício" (MONTROND, 2007, p. 224).

Uma segunda sugestão nos remete à globalização, e aos costumes tradicionais que, mesmo em época pós-moderna, insistem em permanecer e gerar preconceitos e incompreensões: quando um tio-avô de Quina se lança no penhasco para retirar seu corpo, ao içá-lo, sai gritando: "Ela é estátua! A estátua! Tal qual a estátua que vi na América! Só faltava o facho na mão" (Ibidem, p.225). Talvez a liberdade de Quina só fosse possível na imensidão do penhasco, num contexto rural que tem dificuldades em modernizar-se e em reconhecer e praticar a igualdade de direitos entre mulheres e homens.

\subsubsection{FÁTIMA BETTENCOURT}

Hirondina Fátima Bettencourt Fátima Bettencourt Santos nasceu na ilha de Santo Antão, a 16 de fevereiro de 1938. Criança ainda, muda-se com os pais para a 
ilha de São Vicente e cresce e estuda na cidade do Mindelo. Professora (formada em Lisboa), atuou em Cabo Verde, Guiné e Angola e jornalista, produtora e locutora, atuou nas rádios Barlavento e Educativa de Cabo Verde. É membro dirigente da Associação de Escritores Cabo-verdianos.

Galardoada em 2006 por suas crônicas, por esta mesma Associação (AEC), tem produzido contos, crônicas e literatura infanto-juvenil. Suas principais obras são Semear em pó (contos, 1994), A cruz do Rufino (infantil, 1996), Um certo olhar (crônicas, 2001), Mar - caminho adubado de esperança (contos, 2006), Lugar de suor, pão e alegria (crônicas, 2008).

No conto selecionado, "Zora", do volume Mar - caminho adubado de esperança, Bettencourt enfoca alguns aspectos já discutidos nos textos anteriores, mas com uma atualização que merece destaque no que diz respeito às discussões feministas e ao dilema globalização x costumes tradicionais.

O conto inicia-se com uma observação da narradora Gabi (amiga do peito de Zora), que descreve a sua visita bianual a Cabo Verde e aos pais que "insistem em viver como os últimos resistentes duma numerosa família", pois que os membros seguiram, um após outro, "as meninas para a França, os rapazes para a Holanda" (BETTENCOURT, 2006, p. 135).

No entanto, de pronto, a narradora levanta a divisão de gênero como um dos aspectos da emigração: "Esta divisão aparentemente sexista é apenas fruto do gosto pelos estudos das meninas da família e a preferência por dinheiro rápido dos rapazes" (Ibidem).

Gabi apresenta Zora como moça politizada (disposta a derrubar o Partido Único que se estabelecera com a independência de Cabo Verde), ocupante de alto cargo em Ministério.

Ambas revelam-se atuantes na trama, sobretudo na altura da Independência: corriam atrás de comícios, chegadas de dirigentes, reuniões em cadeia, ocupação de rádio, expulsão de agentes da PIDE e Zora "sempre mais activa", "um caso exemplar de entrega total à causa" (Ibidem, p. 136).

Quanto aos costumes, exibiam sua "africanidade", comendo com as mãos, sentadas ao chão, exibiam "indumentárias exóticas e adornos capilares extravagantes", a reivindicar "origens negras, as [nossas] costela vindas do continente africano, a tentar recuperar "um atraso de cinco séculos [...]. Era a própria pátria a iniciar" (Ibidem, p. 137). 
Mas não podemos esquecer que a narrativa de Fátima Bettencourt se insere na esteira da crítica pós-colonial:

Era o estilo crioulo da época, melhorando rapidamente com a aquisição de algumas malas Samsonite. Os povos que nos ensinaram as técnicas da guerrilha, não nos ensinaram o que fazer depois. [...] Teríamos que aprender sozinhos [...] sobretudo como governar um país minúsculo e pobre, perdido no meio do Atlântico (lbidem, p. 139).

O riso contaminará a narrativa, para demonstrar o impasse entre um universo pequeno e essencialmente rural e o mundo globalizado:

Desajeitadamente os nossos políticos passavam do mato para os fora mundiais. Entre os abrigos lamacentos infestados de mosquitos e os hotéis cinco estrelas havia um abismo que os nossos bravos guerrilheiros transpuseram de um salto, considerando de somenos importância pequenos incidentes como ficar entalado numa porta giratória ou num elevador sofisticado, apanhar um jacto de água quente no duche e todas essas armadilhas diabólicas do primeiro mundo (Ibidem, p. 138).

Zora, nesse contexto, "foi uma das mulheres que soube acompanhar a sua época", embora seus pais, pilares da sociedade mindelense, não se dessem conta de que "a estranha rebeldia de sua filha Zora era o disfarce possível para a sua condição de activista política" (Ibidem).

Com a partida dos pais, Zora aprofundou sua opção africanista, inclusive nos namoros, e "enveredou por uma linha nativa, quanto mais escura e mais pobre, melhor. As lutas feministas no seu auge mais o estilo pessoal de Zora não favoreciam relações estáveis" (Ibidem, p. 141).

A personagem-narradora enfatiza, porém que: "De repente sem que nenhuma carta anterior o fizesse prever, Zora, um dia, me comunicou que ia casar com Buba, um ex-guerrilheiro que mal sabia ler e fora recrutado por ser um latagão com físico para suportar as agruras do mato" (Ibidem).

A generosidade e "uma tarefa revolucionária" a leva a tomar como missão fazer de Buba, que não tinha terminado a quarta classe, "um letrado" (Ibidem), preenchendo as "lacunas" deixadas pela luta e, ao fim de três meses, casa-se com ele, apesar da advertência da narradora-personagem quanto "às diferenças entre os 
dois", que Zora qualifica de "preconceitos e rótulos próprios de classes burguesas" (lbidem).

Feita a escolha, cinco anos depois da independência, a narradorapersonagem volta a Cabo Verde, admirada com o avanço da participação política feminina, ao assistir ao "desfile de cerca de dez mil mulheres" (Ibidem, p. 142).

Ao reencontrar Zora, percebe que "o sonho se esfumara deixando um travo amargo, um desencanto, [...] tanto o casamento quanto o entusiasmo político já tinham visto melhores dias" (Ibidem). Ao confessar, finalmente, à amiga, "a sua decepção com a política e com o casamento", Zora argumenta, "debatendo-se em dúvidas": "São diferenças demais! São amarras demais!" (Ibidem).

Zora sonhava um posto diplomático para o marido, mas os avanços acadêmicos não aconteciam. As tarefas partidárias daquele, Zora desconhecia. Ao fim e ao cabo, Zora descobre que o marido tem um filho com outra: arma-lhe, disfarçada, um flagrante e termina o casamento, num "soluçar sem fim" ao despedirse da amiga que viaja para a França. Esta, três anos mais tarde, fica sabendo que Zora fora expulsa do partido, por dissidência.

Com a Segunda República e o pluripartidarismo (democracia), Zora atinge o posto de Ministra da Juventude e Questão Feminina (Ibidem, p. 143). Continuara a estudar, agora Direito, fazendo despontar mais as suas qualidades:

uma inteligência privilegiada, boa cultura geral, domínio de algumas línguas, traquejo social e uma situação económica desafogada. Ironicamente o que parecia jogar a seu favor, agora funcionava em sentido contrário por despertar muita inveja e má vontade entre os seus pares. Entrou em choque com um dos Ministros de Estado, esse sim, verdadeiramente poderoso, fundador do partido que ganhara as eleições, nem por isso dotado de muito cérebro e aí não houve salvação $\{\ldots\}$ o Primeiro Ministro ficou com o fundador (Ibidem, p. 144).

Tendo que sair da residência em uma semana, por represálias sofridas, decidiu então emigrar para os estados Unidos, já que "sentia-se asfixiar em Cabo Verde" (Ibidem, p. 145). Além disto, confessou à narradora-personagem que "as amigas dela estavam montando um plano diabólico de noivar, casar e ficar nos Estados Unidos para sempre" (Ibidem).

A desconfiança da narradora quanto à dificuldade de adaptação de Zora ao "sonho americano" é constatada efetivamente ao fim de quase seis meses, quando a 
amiga the apresenta John, seu noivo "um tanto serôdio, pescado na sua viagem aos Estados Unidos" (Ibidem), que volta com ela ao arquipélago.

John apresenta-se como um cabo-verdiano emigrado há longos anos, cidadão americano, "homem de posses', "no seu típico fato americano, gravata luzidia e anelão rutilando no dedo" (Ibidem, p. 146).

No entanto, o John de Zora era, na verdade, "Junzim de Maria d'Aninha, dono de seu pedacinho de ladeira íngreme numa encosta qualquer de Santo Antão" (Ibidem), ou seja, um pequeno proprietário rural,

quase desconhecido no seu lugarejo de onde saíra dezenas de anos atrás, um jovem [...] empurrado pela ausência total de perspectivas na sua ilha natal devastada pela pobreza e pela seca [...], o seu mundo ao alcance de uma pedra de funda (lbidem).

O casal hospedou-se em casa de Gabi, que narra a estória, e afinal partiu, "levando na mala os papéis para fazer o casamento no Consulado de Cabo Verde em Boston". Este, no entanto, foi adiado por cerca de um mês, por "complicações com a papelada". Enquanto isto, "o verdadeiro John emergia daquele simpático noivo" que se apresentara em Cabo Verde:

Um John prepotente, que só sabia proibir: 'Mulher minha não fuma, mulher minha não trabalha fora...' uma lista enorme de proibições e ameaças, uma situação intolerável numa união baseada em tudo menos no amor. Uma noite Zora acordou, olhou para o homem roncando ao lado e perguntou-se: 'mas o que faço eu ao lado deste homem, que não tem nada a ver comigo, um homem rude, sem educação? $\mathrm{E}$ eu que tive um assim não podia cair de novo no mesmo erro'. Esperou que John saísse para o trabalho, pegou no telefone e contou-me, entre soluços, o que se passava, [...] desesperada". (Ibidem, p. 147)

A ladeira íngreme, espaço natal de Junzim(Joãozinho)-John, configura-se psicologicamente como ladeira abaixo para Zora, que resolve fugir: "Gabriela, minha amiga, minha irmã, tira-me daqui quanto antes" (Ibidem). O conto termina com o seu desejo satisfeito pela amiga, a narradora-personagem Gabi.

Zora é, pois, retratada por Fátima Bettencourt como mulher de diversificadas nuances, ora capacitada e voltada para o sucesso, outras vezes passível de opções infelizes. A narrativa, suspensa na desistência do segundo casamento por parte de Zora, parece não se limitar à compreensão da sua 
imaturidade afetiva, e talvez tenha um intuito maior: que o conto seja levado para fora do texto e continue a repercutir dando possibilidades ao leitor e, sobretudo, às leitoras, de uma reflexão sobre campos em que a atuação feminina poderia, ainda, permanecer em vias de emancipação e libertação menos aceleradas. 


\title{
CONSIDERAÇÕES FINAIS
}

\author{
MEU EU MULHER
}

\author{
...até que um dia \\ farta já da mediania \\ dos vôos rasantes \\ que planam sem ousar \\ me arme de um hino revolucionário \\ e parta \\ em direção a uma madrugada diferente.
}

Vera Duarte

Buscamos acompanhar, neste trabalho, a partir de um corpus selecionado, como a história social das mulheres é representada em Cabo Verde, com apoio à abordagem de gênero e de reflexões teóricas da hermenêutica do cotidiano, num viés feminista. Cotejando textos literários de autoria masculina e feminina, observamos como as mulheres, antes personagens colocadas em exibição por produções masculinas, passam adquirir, na escritura feminina, voz ativa e a expor suas subjetividades, emergindo em grito do silêncio a que as reduzira a história registrada pelos machos dominantes.

Na trilha de Michelle Perrot e Georges Duby (1991, p. 7), percebemos que:

As mulheres foram durante muito tempo, deixadas à sombra da história, é preciso recusar a idéia de que as mulheres seriam em si mesmas um objeto de história. É o seu lugar, a sua condição, os seus papéis e os seus poderes, as suas formas de ação, o seu silêncio e a sua palavra que pretendemos perscrutar, a diversidade de suas representações.

A abordagem do cotidiano feminino em Cabo Verde, o breve diagnóstico que tentamos traçar da situação e da participação das mulheres na construção do país auxiliaram-nos, juntamente com o estudo da relação entre os gêneros (como construções culturais) naquele contexto, a tratar os temas que nos pareceram mais frequentes e pertinentes e os dilemas associados à representação social das mulheres cabo-verdianas na literatura. 
A construção de uma linguagem nova, com novos temas ou assuntos já abordados pela autoria masculina, mas agora enfocados por outros ângulos e diversidade de argumentos, permitiu-nos fazer uma outra leitura da historicidade feminina em Cabo Verde, a partir da perspectiva das mulheres. Como ressalta Elódia Xavier (1991, p. 13), "práticas sociais diferentes geram discursos diferentes".

Para Roger Chartier, um dos expoentes da Nova História Cultural, o principal objetivo dessa corrente historiográfica é identificar o modo como, em diferentes lugares e momentos, uma determinada realidade social é construída, pensada, dada a ler. As representações do social são esquemas incorporados, mas sempre determinados pelos interesses de grupo que as forjam. Portanto, para cada caso, torna-se necessário relacionar os discursos proferidos com o sujeito que os utiliza. Portanto, as práticas sociais, historicamente produzidas, definem as formas de representação.

Margareth Rago (1998, p. 31), sobre a rasura das argumentações da história narrada pelas elites masculinas, esclarece que "[...] é possível dizer que as mulheres estão construindo uma linguagem nova, criando seus argumentos a partir de suas próprias premissas".

Alinhando-se com Maria Odila Leite da Silva Dias, Rachel Soihet (1998, p.108) considera que a história das mulheres e uma nova História. interpenetram-se, num processo dialético, no seguinte procedimento:

[...] a abertura dos historiadores para os papéis informais, visíveis apenas através do enfoque do cotidiano, constitui-se no recurso possível para o atingir de nosso objetivo; qual seja, o de obter pistas que possibilitem a reconstrução da experiência concreta das mulheres em sociedade, que têm desempenhado um papel ativo na criação de sua própria história.

Nossa análise procurou, a partir do cotejo das leituras efetuadas passo a passo, demonstrar como, na abordagem literária de autoria feminina, mulheres prostituídas, espancadas, enganadas, humilhadas, violentadas, abandonadas, enfermas, loucas, alcoolizadas podem dar lugar a mulheres rebeldes, vencedoras e produtoras de contradiscursos que rasuram, de dentro, no campo cotidiano do miúdo e do detalhe, o arcabouço do poder patriarcal (cf. RAGO, 1998, p. 23).

Com o questionamento das normas e papéis preestabelecidos, as mulheres passam a construir um contradiscurso que coloca "face a face [...] duas visões de 
mundo", introduzindo "a incerteza, a pluralidade e a escolha onde anteriormente só havia certeza, unanimidade e conformidade", como enfatiza Rosiska Darcy de Oliveira (1993, p. 72).

Pautado pelas postulações acima expostos, o pós-feminismo examinará as fissuras à dominação patriarcal, por intermédio de estratégias de resistência geradas com a "reapropriação" e o "desvio" dos instrumentos simbólicos do dominador, como, por exemplo, a "linguagem da dominação" (Ibidem, p. 107).

Assim, ao abordar o cotidiano das mulheres e suas experiências vividas como papéis informais de resistência, os estudos feministas, hoje, caminham na vanguarda crítica das Ciências Humanas e a "crítica feminista torna-se contextual, histórica e relativista" (DIAS, 1994, p. 375).

Com base no exposto, dos textos selecionados para corpus representativo do discurso masculino, pudemos constatar a frequência da apresentação de temas que se associavam a formas de exclusão social e de discriminação das mulheres em Cabo Verde, com base no sexo e na relação de gêneros ancorada em estereótipos de inferioridade feminina.

A prostituição, a violência sofrida pelas mulheres por parte dos companheiros eventuais ou estáveis, a violação dos direitos, a existência de filhos de vários homens, a restrição do espaço honrado feminino ao lar e ao casamento, apresentados pela ótica masculina, assim como a relação entre pobreza, falta de instrução e exclusão formam um núcleo temático de consistência nos textos caboverdianos de autoria masculina. Também a ênfase nos procedimentos de conquista e dominação das mulheres, encaradas como objetos por parte dos homens (como propõe Suzana Funck, 2003, p. 476), estão por detrás das estórias centradas nas personagens femininas.

Estas são apresentadas como reprodutoras incansáveis, libertinas ou ingênuas sonhadoras e imaturas, regendo-se sua construção pela dualidade maternidade-virgindade imaculada $X$ prostituição/libertinagem, com base numa ótica "!instrumental e descartável" do prazer masculino (FUNCK, 2003, p. 476).

A vitimização das personagens femininas é um dado comum que restringe as suas atuações e expõe as discriminadas socialmente (prostitutas, alcoólatras, viciadas, perturbadas mentalmente, imaturas) a juízos morais que as elegem como exemplos do que não deve constituir a conduta feminina qualificada pela sociedade. 
Os conceitos de honra e vergonha são associados à atuação das mulheres, pautando seus comportamentos e limitando-lhes os direitos à liberdade de ação e expressão ou encobrindo a importância de suas participações na construção da cultura e da sociedade a partir de seu cotidiano.

A prostituição, por exemplo _ um dos temas mais recorrentes no corpus literário masculina ao representar as mulheres cabo-verdianas _, considerada como fenômeno urbano, passou a ser encarada, com o crescimento, como um problema público e verdadeira arma para conter o ingresso das mulheres na vida pública, tendo em vista que não era aceitável a permanência feminina nos espaços tidos como masculinos.

Representar a prática da prostituição em associação à marginalidade (localizar as mulheres num espaço especial e marginal, o Lombo) ou à doença tem sido uma estratégia utilizada, como podemos observar no conto A caderneta, de Baltasar Lopes.

As estereotipias morais (mulher perdida, borboleta evadida) e o uso do calão podem ainda integrar-se a esse núcleo de submissão e vitimização das mulheres.

Não esqueçamos que Fátima Bettencourt (2001, p.50) denuncia já, em contexto cabo-verdiano, a inserção precoce das mulheres cabo-verdianas no universo dos objetos de consumo, referindo as "prostitutas ainda com a boneca escondida no travesseiro? [...] o boteco da esquina onde corpos gentis de adolescentes se leiloam".

Esta situação histórica, como anteriormente esclarecemos, ligada ao auge do funcionamento do Porto Grande na ilha de S. Vicente, leva o olhar masculino a retratar literariamente a prostituição, os corpos femininos, sua sensualidade aliada à juventude, a ingenuidade feminina e a ausência de instrução e traquejo social em associação freqüente à pobreza material.

Assim, os contos "A caderneta", de Baltasar Lopes, "Lulucha" e "Titina", de Virgílio Pires, "Bèlinha foi ao baile pela primeira vez" e "Uma flor entre os cardos", de Manuel Ferreira, "Beira de cais", de Teobaldo Virgínio, "Borboleta evadida" e "Rebindita", de Oswaldo Osório, focalizam temática semelhante: a prostituição ou o caminho para ela, resumidos na trajetória de quase meninas que têm sua primeira experiência amorosa e/ou que sucumbem à conquista masculina e são vendidas 
pelo pai bêbado ao agente da sedução; ou de borboletas evadidas, rebinditas (vendidas) e mulheres de beira de cais; finalmente, chegam a ser fichadas como profissionais, por meio de uma caderneta que controlará sua saúde em prol, grande parte das vezes, da própria comunidade que fecha os olhos à exploração sexual.

Na maioria dos contos de autoria masculina selecionados, não há redenção para as personagens femininas, retratadas com ênfase nos seus dotes físicos como atraentes objetos de desejo e como vítima dos perigos que um futuro fatal lhes destinará. O determinismo, não raro, acompanha o histórico dessas personagens mulheres, de quem se espera um estatuto virginal ou um honroso casamento, sendo qualquer passo em falso nesse sentido equivalente a uma condenação.

Apenas uma das "virgens loucas" ou prostitutas apresentadas por António Aurélio Gonçalves escapará a esse quadro: Betinha encontra, quando à procura de óleo para alimentar a chama do candeeiro, sua "réstia de luz" naquele "poluído" submundo de miséria moral e física: a emigração e o consequente casamento com um estrangeiro, uma "casa com luzes bonitas".

Nesse quadro determinado e restrito aos vôos femininos, o casamento e uma casa honrada são saídas mais fáceis e preferíveis à emigração como prostituta para Dacar.

Assim, Betinha passa de mulher prostituída a se considerada como mulher normal, sendo esta normalidade construída num modelo popular que se funda na imagem da Virgem Maria Santíssima, rainha do lar e da maternidade. Do espaço privado, portanto. Aos "amores de rua", como intitula Oswaldo Osório, caberá o espaço público, mas também a desonra da Eva da serpente.

No caso do corpus literário cabo-verdiano de autoria feminina, ressalta dele, como já sublinhado por Hélène Cixous (apud OLIVEIRA, p. 130), além do "escrever sobre as mulheres", a emergência do "escrever-se", colocando-se muitas vezes, além das vozes, dos sentimentos e dos argumentos das personagens femininas, as considerações de uma narradora que se torna cúmplice desse universo representado e que questiona os estereótipos que toldam as atuações e oferecem obstáculos às decisões femininas, propondo formas de superação das discriminações e exclusões.

A produção literária feminina traz à tona temas que revelam as experiências sociais das mulheres de Cabo Verde, seus dilemas, paixões e desencantos, suas 
angústias, seus medos e também suas vitórias, buscando representar a diversidade do cotidiano de mulheres que reinventam a vida e a trajetória histórica no dia-a-dia. Como diria Fátima Bettencourt:

\begin{abstract}
Mulheres jovens maduras, idosas, cada uma o seu encanto, a sua força. (...). Uma mulata explode na dança de um vestido curto amarelo gema de ovo, a saia esvoaça no compasso do ritmo, revela no saracoteio o corpo bonito sugerindo o que não mostra. Mulheres vendedeiras complementam e rentabilizam o suor do seu homem. As da terra e as do mar. (...) Em todas a mesma dignidade e a certeza de pertencerem a um chão que fez delas' guerrilheiras' da vida de onde sacam a pulso a determinação e a vontade de vencer, mas também a alegria e a musicalidade de todos os gestos e a sabedoria secular que lá de longe se vem acumulando até hoje (BETTENCOURT, 2001, p. 236).
\end{abstract}

A redução operada por uma visão vitimizadora, miserabilista, é expandida nos textos femininos.

Nos contos de Ivone Aída, por exemplo, o cotidiano da protagonista Tanha, mulher de pescador em "Destino dum Criol", gira em torno da família, do marido e do filho macho, que Zé Catoque almeja que herde dele as artes da pesca, mas que acaba sua vida como pescador de lixo à beira do cais (RAMOS, 1990). A subjetividade de Tanha e a recusa a que o filho tenha o mesmo destino trágico do pai, morto no mar, pontuam a narrativa, mas acabam por não impedir que o "criol" (o crioulo, tal pai, tal filho) cumpra o seu "destino".

O conto "Promessa", ao contrário, narra a estória de Bia, "menina de vida" que habita o espaço periférico (e estigmatizado pela prostituição) de Lombo de Trás, e de outras mulheres do segmento social conhecido como "pé descalço" (Peixeira, 2003, p.150), como Djéna, que trabalhava para o sustento dos filhos face à emigração do marido, ou meretrizes como Canda e Manuela, mas já coloca outras nuances do cotidiano feminino cabo-verdiano em discussão, como a emigração masculina e o conseqüente abandono da família, o exagerado número de filhos por mulher, a violência doméstica por motivos vários, sobretudo a bebedeira do companheiro, o preconceito contra as prostitutas e a dificuldade de abrigá-las no mercado de trabalho considerado "digno", a animalização do sexo, o casamento como meio de enobrecimento da mulher, as tarefas informais que esta precisa assumir para o sustento dos filhos e, às vezes, do marido retornado da emigração sem sucesso. 
A solidariedade entre mulheres "da casa" e "da vida", personificadas por Djena e Bia, e a árdua luta desta por realizar o seu sonho de ter um trabalho honrado pela sociedade e uma família, ao invés de viver diariamente a humilhação de "se vender para agradar ao homem", são qualidades fartamente detalhadas pela narrativa de Ivone Aída, configurando as personagens citadas como duas resistentes, vencedoras dos obstáculos que a elas se põem, especialmente porque não estão sozinhas na luta, mas irmanadas na força.

Contudo, mesmo a solução do casamento para Bia é questionada nesta narrativa, na voz de Canda, demonstrando que a escritura feminina está atenta às estruturas e armadilhas que o poder patriarcal teima em espalhar.

A "Toia" de Maria Margarida Mascarenhas, representante, segundo a autora, de 'todas as 'Toias-mulheres' e 'todas as 'Toias-situação-condição' ", analfabeta, emigrada, mãe de filhos de vários homens, prostituída, abandonada na diáspora, merecerá a cumplicidade de uma narrador que a retrata como Antónia do Nascimento, grito reprimido que tem que brotar, nascer para a conquista de seus direitos. Assim também Paula, protagonista do conto "Vigília", sintetiza a maturação sexual precoce, as escolhas afetivas equivocadas, a vítima de violência doméstica, a mãe de filhos de vários parceiros, mas opta por se rebelar num contradiscurso de silêncios e recusas no seu comportamento doméstico para com o marido.

No texto de Dina Salústio esses gritos travados na garganta (e outros) realmente explodirão em palavras e atos: uma das vozes mais contundentes do cânone cabo-verdiano no que diz respeito a temas sociais, Dina trabalha em seus contos com a gravidez precoce, a adolescência muito cedo transformada em maturidade pela iniciação sexual prematura, a pedofilia, o voyeurismo masculino, a violência a que se submetem mulheres de família e prostitutas, a exploração sexual e a hipocrisia social que muitas vezes acompanha tal quadro.

Mas as personagens femininas por Salústio representadas, assim como uma narradora (ou personagem-narradora) freqüente nos contos, não aceitam passivamente essa realidade: rebelam-se, revoltam-se, sentem ódio, gritam, matam.

E compadecem-se da fraqueza e do sofrimento de outras mulheres, numa verdadeira cumplicidade entre fêmeas, como ressalta o próprio texto de Dina Salústio. As mulheres cabo-verdianas se revelam, nos contos de Dina, na sua diversidade, fracas e fortes, submissas a algumas circunstâncias e resistentes a outras, semelhando a trajetória de seus vários cotidianos. 
O conto "O Suicídio de Quina", de Camila Mont-Rond, traz uma personagem feminina com instrução como protagonista, mas enfatiza a tragicidade da circunstância de ser virgem, embora com uma formação rara do hímen, numa comunidade que não tem possibilidade de compreender tal fato e que exige certos rituais machistas. Impelida pela família, Quina é levada ao suicídio, em prol da honra daquela e da comunidade. A par da punição da personagem, que corrobora a estrutura patriarcal opressora, a narrativa problematiza vários estereótipos como "do homem a rua, da mulher a casa", o casamento da mulher cabo-verdiana com um estrangeiro, a noção de honra atrelada ao espaço privado, à virgindade e à maternidade, entre outros.

Por fim, Fátima Bettencourt, no conto Zora, questiona as escolhas equivocadas de uma personagem politizada e instruída, uma típica ativista política, que insiste, na vida afetiva, em relacionar-se segundo modelos desgastados e que dificultam a sua realização. Ora casa-se com um homem fisicamente bem apresentado, mas que se distancia dela por um fosso cultural, ora com um caboverdiano emigrado, cuja aparência esconde comportamentos machistas que se pautam pela submissão feminina. Em ambos os casos, Zora toma o ideal ou a aparência como caráter e não consegue equilibrar a sua inteligência e agilidade mentais e profissionais com a sua inteligência emocional.

Em síntese, o texto de autoria feminina tem procurado, em Cabo Verde, documentar experiências vividas como possibilidades de abertura de caminhos, fazendo emergir não apenas a história da dominação masculina e das exclusões que tem imposto às mulheres, mas dando destaque, "sobretudo, aos papéis informais, às improvisações, à resistência das mulheres" (DIAS, 1994, p. 374) diante de um contexto que nem sempre as favorece, deixando entrever "uma pluralidade de [...] processos de vir a ser de novas subjetividades femininas até há pouco invisíveis e insondáveis" (Ibidem, p. 382). 


\section{REFERÊNCIAS BIBLIOGRÁFICAS}

\section{OBRAS LITERÁRIAS:}

BETTENCOURT, Fátima. "Zora". In: Mar - caminho adubado de esperança (contos). Praia: Instituto da Biblioteca Nacional, 2006. P. 135-147.

Biblioteca Nacional, 2001. P. 50 e 236.

Um certo olhar... (Crônicas). Praia: : Instituto da

DUARTE, Vera. "Violência". In: Preces e súplicas ou cânticos da desesperança. Lisboa: Instituto Piaget, 2005.

FERREIRA, Manuel. "Bèlinha foi ao baile pela primeira vez". In: Terra trazida. Lisboa: Plátano, 1972a.

"Uma flor entre os cardos". In: Terra trazida. Lisboa: Plátano,

1972b.

FERREIRA, Ondina (org) ou MONT-ROND, Camila. "O suicídio de Quina". In: Elas contam... Praia: Instituto da Biblioteca Nacional e do Livro, 2007. P. 219-225.

GONÇALVES, António Aurélio. "Virgens loucas". In: DUARTE, Dulce Almada e ALFAMA, Jorge Miranda (orgs). Antologia da ficção cabo-verdiana. Claridosos. Vol II. Praia: AEC, 2001. P. 35-57.

LOPES, Baltasar. Chiquinho. São Paulo: Ática, 1986.

. "A Caderneta". In: DUARTE, Dulce Almada e ALFAMA, Jorge Miranda (orgs). Antologia da ficção cabo-verdiana. Claridosos. Vol II. Praia: AEC, 2001. P.103-108.

MASCARENHAS, Maria Margarida. "Toia". In: SILVA, Tomé Varela da (org). Antologia da ficção cabo-verdiana. Pós-claridosos. Vol III. Praia: AEC, 2002. P. 543-546.

contam... Praia: Instituto da Biblioteca Nacional e do Livro, 2007. P. 79-82.

"Vigília". In: FERREIRA, Ondina (org). Elas

Levedando a Ilha. Praia.: ICL-Instituto

Caboverdiano do Livro e do Disco, 1988.

OSÓRIO, Oswaldo. "Borboleta Evadida". In: Nimores e Clara \& amores de rua. Praia: Spleen, 2003. P. 109-110.

2003. P. $119-122$.

. "Rebindita". In: Nimores e Clara \& amores de rua. Praia: Splen, 
PIRES, Virgílio Avelino. "Lulucha". In: DUARTE, Dulce Almada e ALFAMA, Jorge Miranda (orgs). Antologia da ficção cabo-verdiana. Claridosos. Vol II. Praia: AEC, 2001. P. 497-501.

"Titina". In: DUARTE, Dulce Almada e ALFAMA, Jorge Miranda (orgs). Antologia da ficção cabo-verdiana. Claridosos. Vol II. Praia: AEC, 2001. P. 503-506.

RAMOS, Ivone Aida Fernandes. "Destino dum criol". In: Vidas vividas: Organização de Mulheres de Cabo Verde O.M.C.V. São Vicente: 1990. P. 9-27.

"Promessa". In: SILVA, Tomé Varela da (org).

Antologia da ficção cabo-verdiana. Pós-claridosos. Vol III. Praia: AEC, 2002. P. 371-400.

SALÚSTIO, Dina. Mornas eram as noites. Praia: Instituto Caboverdiano do Livro e do Disco, 1994.

VIRGÍNIO, Teobaldo. "Beira de Cais". In: DUARTE, Dulce Almada e ALFAMA, Jorge Miranda (orgs). Antologia da ficção cabo-verdiana. Claridosos. Vol II. Praia: AEC, 2001. P. 457-463.

\section{OBRAS DE ABORDAGEM TEÓRICA, CRÍTICA E CONTEXTUAL:}

ABDALA JR., Benjamin. De vôos e ilhas: literatura e comunitarismos. São Paulo: Ateliê Editorial, 2003.

AGUIAR, Neuma. Gênero e Ciências Humanas: desafio às Ciências desde a perspectiva das mulheres. Rio de Janeiro: Rosas dos Tempos, 1998.

ALVES, Fábio Lopes e STADNIKY, Hilda P. Prostituição feminina na imprensa periódica de Cascavel: entre práticas e representações. Simpósio Temático apresentado no X Encontro Regional da ANPUH-PR. Universidade Estadual de Maringá, 2006.

ARIÉS, Philippe \& BEGIN, André (orgs.). Sexualidades ocidentais. Trad. Lygia Ferreira Stummer. 2. ed. São Paulo: Brasiliense, 1986.

BACELAR, Jeferson Afonso. A família da prostituta. São Paulo: Ática, 1982.

BACHELARD, Gaston. A terra e os devaneios do repouso: ensaio sobre as imagens da intimidade. Paulo, Martins Fontes, 1990.

BASSERMAN, Luja. História da prostituição: uma interpretação cultural. Trad. Rubens Stckenbruck. Rio de Janeiro: Civilização Brasileira, 1968.

BEAUVOIR, Simone de. O segundo sexo: a experiência vivida. 2. ed. São Paulo: Difusão Européia do Livro, 1967. 
BRITO-SEMEDO, Manuel. A construção da identidade nacional - análise da imprensa entre 1877 e 1975. Praia: Instituto da Biblioteca Nacional e do Livro. 2006.

CANDIDO, Antonio. "A personagem do romance". In: A personagem de ficção. São Paulo: Perspectiva, 1992.

CARDOSO, Pedro (Org.). Textos jornalísticos e literários. Parte I. Praia: Instituto da Biblioteca Nacional e do Livro, 2008.

CARREIRA, António. Cabo Verde: classes sociais, estrutura familiar, migrações. Lisboa: Ulmeiro, 1977.

CARVALHAL, Tânia, Franco. Literatura comparada: textos fundamentais. Rio de Janeiro: Rocco, 1994.

CHARTIER, Roger. A história cultural entre práticas e representações. Lisboa: Difel, 1998.

COMITÉ NACIONAL DOS DIRETOS HUMANOS. Plano Nacional de Acção para os Direitos Humanos e a Cidadania em Cabo Verde. Praia, CNDH, 2004.

COUTO, Carlos Ferreira. Estratégias familiares de subsistências rurais em Santiago de Cabo Verde. Lisboa: Instituto da Cooperação Portuguesa Ministério dos Negócios Estrangeiros, dezembro de 2001.

CUCHE, Denys. A noção de cultura nas Ciências Sociais. São Paulo: EDUSC. , 2002.

DELGADO, Liriam Tiujo (org) Cabo Verde e a CEDAW. Relatório à Convenção sobre a Eliminação de Todas as Formas de Discriminação contra as Mulheres e Documentos Conexos. Praia: Instituto Cabo-verdiano para a Igualdade e Equidade de Gênero (CIEG), 2007.

DEPRAETERE, Marguerite. Estudos monográficos sobre o papel da mulher rural na organização dos recursos e consumos. Oeiras: Centro de Estudos de Economia Agrária, Instituto Gulbenkian de Ciências, 1983, mimeo.

DIAS, Maria Odila Leite da Silva. "Teoria e método dos estudos feministas: perspectiva histórica e hermenêutica do cotidiano". In: COSTA, Albertina de Oliveira e BRUSCHINI, Cristina (Orgs). Uma questão de gênero. São Paulo: Fundação Carlos Chagas, 1992. P. 39-53.

"Novas subjetividades na pesquisa histórica feminista: uma hermenêutica das diferenças". In: Estudos feministas. Vol.2, n.2, 1994. P. 373-382.

"Hermenêutica do cotidiano na historiografia contemporânea". In: Projeto. História - trabalhos da memória. São Paulo, nํ17, nov/98. P. 223-232. 
DUARTE, Constância Lima. "O cânone literário e a autoria feminina". In: AGUIAR, Neuma. Gênero e Ciências Humanas: desafio às ciências desde a perspectiva das mulheres. Rio de Janeiro: Record-Rosa dos Tempos, 1997. P. 85-94.

DUARTE, Vera. Construindo a utopia. Temas e conferências sobre direitos humanos. Praia: Tipografia Santos Ltda, 2007.

DUBY, Georges; PERROT, Michelle. História das mulheres no Ocidente: o séc XIX. Vol. 4. Porto: Afrontamento, 1991.

FERRAZ, Esther de Figueiredo. Conferência na Escola de Polícia da Secretaria da Segurança Pública: XIII Semana de Estudos Policiais: Pontifícia Universidade Católica de São Paulo. A prostituição, forma remanescente de escravatura feminina. São Paulo: [s.n.], 1952.

FERREIRA, Manuel. A aventura crioula. Lisboa: Plátano, 1985.

FRANÇA, Arnaldo. Prefácio a GONÇALVES, António Aurélio. Recaída. 1. ed. Lisboa: Vega : Instituto Caboverdiano do Livro, 1993

FREITAS, Renan Springer de. Bordel, bordéis: negociando identidades. Petrópolis: Vozes, 1985.

FOUCAULT, Michel. História da sexualidade. Trad. Maria Thereza da Costa Albuquerque. 3. ed. Rio de Janeiro: Graal. 3v. 1985.

A ordem do discurso. São Paulo: Loyola, 1996.

FUNCK, Susana Bornéo. "O jogo das representações". In: BRANDÃO, Isabel \& MUZART, Zahidé L. Refazendo nós: ensaios sobre mulheres e literatura. Florianópolis: Ed. Mulheres, 2003. P.475-481.

GAMA, Maria João. O universo feminino em António Aurélio Gonçalves. Praia: Instituto Camões-Centro Cultural Português, 2009.

GOMES, Irineu. Juventude e adolescência, mulher e sociedade: psicopatias e desequilíbrios emocionais. Praia: Instituto Caboverdiano do Livro, 1986.

GOMES, Simone Caputo. Uma recuperação de raiz. Cabo Verde na obra de Daniel Felipe .Praia: Instituto Caboverdiano do Livro e do Disco, 1993.

Ateliê Editorial, 2008.

. Cabo Verde: literatura em chão de cultura. São Paulo:

"Mulher com paisagem ao fundo: Dina Salústio apresenta Cabo Verde". In: SEPÚLVEDA, M. C. \& SALGADO, M. T. (org.), África \& Brasil: letras em laços. Rio de Janeiro, Atlântica, 2000. P. 113-132.

GONÇALVES, Antonio Aurélio (Org.). Ensaios e outras escritas. Praia: 1998. 
GOVERNO DE CABO VERDE. Programa de Cooperação 2000-2004. Análise de situação: Crianças e Mulheres em Cabo Verde. Praia: Fundo das Nações Unidas para a Infância, 1999.

GRASSI, Marzia. Gênero, empresariado e desenvolvimento em contextos não ocidentais: rabidantes do mercado Sucupira em Cabo Verde. Tese de doutoramento. Lisboa: ISCTE, maio de 2001. Policopiado.

GUATTARI, Félix \& ROLNIK, Suely. Micropolítica: cartografias do desejo. 4.ed. Petrópolis: Vozes, 1996.

HAMILTON, Russell. Literatura africana, literatura necessária. Lisboa: 1984.

HOLLANDA, Heloísa Buarque de (org). Tendências e impasses: o feminismo como crítica da cultura. Rio de Janeiro: Rocco, 1994.

LABAN, Michel. Cabo Verde: encontro com escritores. Porto: Fundação Engenheiro António de Almeida, 1992.

LARANJEIRA, Pires. Literaturas africanas de expressão portuguesa. Lisboa: Universidade Aberta, 1995.

LAURETIS, Teresa de. "A tecnologia de gênero". In: HOLLANDA, Heloísa Buarque de (org). Tendências e impasses: o feminismo como crítica da cultura. Rio de Janeiro: Rocco, 1994. P. p. 206-242.

LOPES FILHO, João. Ilha de S. Nicolau : Cabo Verde : formação da sociedade e mudança cultural. 1. ed. - Lisboa : Secretaria-Geral - Ministério da Educação, 1996.

. Imigrantes em terra de emigrantes. Praia: Instituto da Biblioteca Nacional e do Livro (IBNL), 2007,

Caminho, 1995.

Cabo Verde: retalhos do quotidiano. Lisboa: Editorial

MACHADO, Álvaro Manuel \& PAGEAUX, Daniel-Henri. Da literatura comparada à teoria da literatura. Lisboa: Edições 70, 1981.

MARIANO, Gabriel. Cultura caboverdeana: ensaios. Lisboa: Vega, 1991.

MATOS, Maria Izilda Santos de. "Gênero e história: percursos e possibilidades". In: SCHPUN, Mônica Raisa. Gênero sem fronteiras: oito olhares sobre mulheres e relações de gênero. Florianópolis: Ed. Mulheres, 1997. P.73-91.

MEINTEL, Deirdre. “Emigração em Cabo Verde: solução ou problema?”. In: Revista internacional de estudos africanos, 2, 1984, p.93-120.

MOISÉS, Massaud. A literatura como denúncia. São Paulo: Íbis, 2002. 
MONTEIRO, Eurídice Furtado. Mulheres, democracia e desafios pós-coloniais: uma análise da participação política das mulheres em Cabo Verde. Praia: Imprensa Nacional de Cabo Verde, 2009.

OLIVEIRA, Rosiska Darcy de. Elogio da diferença: o feminino emergente. 3.ed. S. Paulo: Brasiliense, 1993.

PEIXEIRA, Luís Manuel de Sousa. Da mestiçagem à caboverdianidade: registros de uma sociocultura. Lisboa: Edições Colibri, 2003.

PEREIRA, Daniel. A. Estudos da história de Cabo Verde. Praia: AlfaComunicações, 2005.

PERROT, Michelle. Os excluídos da história: operários, mulheres e prisioneiros. Rio de Janeiro: Paz e Terra, 1988.

PROENÇA, Carlos Sangreman. A exclusão social em Cabo Verde: uma abordagem preliminar. Lisboa: Coleção de Documentos de Trabalho № 76, 2005.

QUEIROZ, Sonia. "Literatura e cultura cabo-verdiana: Baltasar Lopes ou simplesmente Nhô Baltas". In: Revista Eletrônica de Divulgação Científica em Língua Portuguesa, Lingüística e Literatura. Ano 05 n.10 - 1o Semestre de 2009.

Divulgação Científica da FALS. Ano III - № V- Jun/ago de 2009.

"Virgílio Pires - Lulucha e Titina". In: Revela: Periódico de

RAGO. Margareth. "Epistemologia feminista, gênero e história". In: PEDRO, Joana Maria \& GROSSI, Miriam Pillar. Masculino, feminino,plural: gênero na interdisciplinaridade. Florianópolis: Ed. Mulheres, 1998. P. 21-41.

. "Descobrindo historicamente o gênero". In: Cadernos Pagu, 11, Campinas, 1998. P. 89-98.

Os prazeres da noite: prostituição e códigos da sexualidade feminina em São Paulo, 1890-1930. Rio de Janeiro: Paz e Terra, 1991.

ROCHA-COUTINHO, Maria Lúcia. Tecendo por detrás dos panos: a mulher brasileira nas relações familiares. Rio de Janeiro: Rocco, 1994.

ROMANO, Luís. Clima: poemas. Recife: Imprensa. Oficial, 1963.

SANTILLI, Maria Aparecida \& FLORY, Suely Fadul Villibor (org). Literaturas de língua portuguesa: marcos e marcas. Cabo Verde. São Paulo: Arte \& Ciência, 2007.

SCHWANTES, Cíntia. "Espelho de Vênus: questões da representação do feminino". In: BRANDÃO, Isabel \& MUZART, Zahidé L. Refazendo nós: ensaios sobre mulheres e literatura. Florianópolis: Ed. Mulheres, 2003. P. 392-400. 
SCHWARCZ, Lilia Moritz. Introdução: O Espetáculo da miscigenação. São Paulo: Companhia das Letras, 1993.

SCOTT, Joan. "Gênero: uma categoria útil de análise histórica". In Revista Educação e realidade, n. 2, vol. 16, Porto Alegre, jul/dez de 1990. P. 5-22.

"História das mulheres". In: BURKE, Peter (Org.). A escrita da história: novas perspectivas. São Paulo: Ed. Unesp, 1992. P. 62-95.

SILVA, António Leão Correia e. Nos tempos do Porto Grande do Mindelo. PraiaMindelo: Centro Cultural Português, 2005.

SILVA, Vítor Manuel de Aguiar e. Teoria da literatura. Coimbra: Almedina, 1983.

SOIHET, Rachel. "História, mulheres, gênero: contribuições para um debate". In: AGUIAR, Neuma. Gênero e Ciências Humanas: desafio às Ciências desde a perspectiva das mulheres. Rio de Janeiro: Rosas dos Tempos, 1998. P. 95-114.

TAVARES, Eugénio. In: MONTEIRO, Félix (Recolha). Eugénio Tavares: poesia, conto, teatro. Praia: Instituto Caboverdiano do Livro, 1996, p. 49.

TILLY, Louise A. "Gênero, história das mulheres e história social". In: Cadernos Pagu, 3, Campinas, 1994. P. 29-62.

VEIGA, Manuel (org.). Cabo Verde: insularidade e literatura. Paris: Karthala, 1998. P. 122/ 172- 3 189-192.

WOOLF, Virginia. Um teto todo seu. Rio de Janeiro: Nova Fronteira, 2004.

XAVIER, Elódia. Tudo no feminino: a mulher e a narrativa brasileira contemporânea. Rio de Janeiro, Francisco Alves, 1991.

\section{WEBGRAFIA:}

ANJOS, José Carlos Gomes. Sexualidade juvenil de classes populares em Cabo Verde: os caminhos para a prostituição de Jovens Urbanas Pobres. 2005. On-line em 09/05/2010.

www.cndhc.org/dowloads.php\%3

Cabo Verde: pedofilia e crianças correios de droga. Página Um blogspot, 2007. Online em 18/05/2010.

http://pagina-um.blogspot.com/2007/12/cabo-verde-pedofilia-e-crianas-correios.html

Declaração de Pequim adotada pela quarta Conferência Mundial sobre as Mulheres:

Ação \& Igualdade, Desenvolvimento e Paz 1995. On-line em 09/06/2010.

http://www.dhnet.org.br/direitos/sip/onu/doc/pequim95.htm.

DUARTE, Migração clandestina e tráfico de mulheres. On-line em 29/05/2010. www.cndhc.org/download.php?\&id=53 
Estudo revela casos de pedofilia em Cabo Verde. Expresso das ilhas. 29-11-2007. On-line em 27/05/2010.

http://www.expressodasilhas.sapo.cv/noticias/detail/id/1405/

FIGUEIRA, Tchalê, Artafrica-Centro de Estudos Comparatistas: Faculdade de Letras - Universidade de Lisboa. Exposição Virtual. On-line em 19/05/2010 http://www.artafrica.inf/html/expovirtual/expovirtual.php?ide $=4$

GOMES, Simone Caputo. Amar Cabo Verde. On-line em 19/05/2010. www.simonecaputogomes.com

Gravidez leva 10\% das jovens de Cabo Verde a largar estudo. Cidade da Praia, 25/10/2009. On-line em 27/05/2010.

http://noticias.uol.com.br/ultnot/lusa/2009/10/25/ult611u82993.jhtm

Ministério das Finanças e Administração Pública- Direção Geral do Planejamento: Documento de estratégia de Crescimento e Redução da Pobreza-II, maio, 2008. Online em 01/06/2010.

www.governo.cv/documents/DECRP - II -PDF

MOREIRA, Diego de Albuquerque Alves. O riso legítimo de Mornas eram as noites, de Dina Salústio. On-line em 08/06/20010.

www.uea angola.org/artigo.cfm?1D=919

PROENÇA, Carlos Sangreman. A exclusão social em Cabo Verde: uma abordagem preliminar. On-line em 10/06/2010.

http://pascal.iseg,utl.pt/ cesa doc tab76.pdf

RISO, Ricardo. Dina Salústio. On-line em 10/06/2010.

http://www.africaeafricanidades.com/Riso 1-ed.html

SANTOS Eduino. Rádio Atlântico-Holanda: A mais nova cara da prostituição no Mindelo. On-line em 10/06/2010.

www.skiptomain.skiptosidebar

SILVA, António Correia e. Ciclos históricos de inserção e marginalização de Cabo Verde. As invenções de Cabo Verde. On-line em 20/06/2010.

www.virtualcapeverde.net/dowloads/forum/corsilva.doc

SILVA, António Correia e. PIRES, Fernando. A Influência do Porto na formação e configuração das cidades Cabo-Verdianas: Ribeira Grande, Praia e Mindelo. On-line em 11/06/2010.

http://users.domaindlx.com/africadebate/ad1\%20correia\%20e\%20silva\%20fernando \%20pi

SOIHET, Rachel. História das mulheres e relações de gênero: Algumas reflexões. NEC- Núcleo de Estudos Contemporâneos. 1997. On-line em 10/05/2010. www.historia.uff.br/nec/textos/text33 
Uma problemática chamada gravidez precoce: mal me quer, bem me quer. Expresso das ilhas, 9-11-2008. On-line em 13/06/2010.

http://www.expressodasilhas.sapo.cv/noticias/detail/id/6201/

Violência contras as mulheres. Mulheres caboverdianas blogspot. On-line em 10/06/2010.

http://mulherescaboverdiana.blogspot.com/2007/08violencia-contra-asmulheres 1186.html 